UNIVERSIDADE DE SÃO PAULO

FACULDADE DE FILOSOFIA, LETRAS E CIÊNCIAS HUMANAS

DEPARTAMENTO DE HISTÓRIA

PROGRAMA DE PÓS-GRADUAÇÃO EM HISTÓRIA SOCIAL

BRUNO ROMANO RODRIGUES

\title{
EXÍLIOS PORTUGUESES
}

\section{DURANTE A UNIÃO DAS COROAS IBÉRICAS (1604-1605)}

Dissertação apresentada ao Programa de Pós-Graduação em História Social do Departamento de História da Faculdade de Filosofia, Letras e Ciências Humanas da Universidade de São Paulo, para obtenção do título de Mestre em História.

Orientadora: Profa. Dra. Ana Paula Torres Megiani

De acordo.

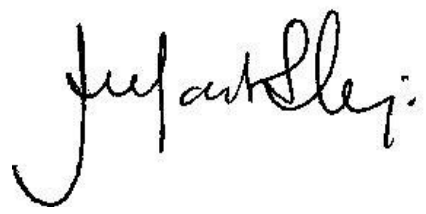

Este exemplar é uma versão corrigida

SÃO PAULO 


\section{SUMÁRIO}

Relatório de defesa .......................................................................... 3

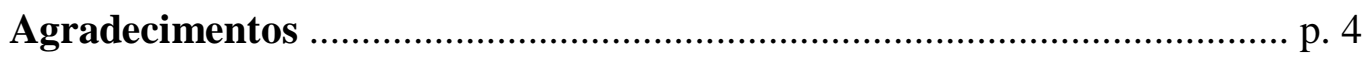

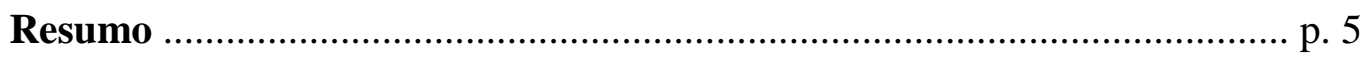

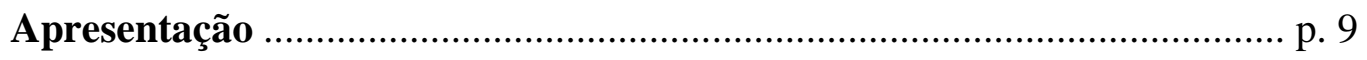

Introdução: Penso, logo exílio ................................................................ p. 10

\section{Capítulo 1 - Exílio: fenômeno multifacetado}

1. 1. Sentidos existenciais:

expressões de um sentimento .......................................... p. 14

1. 2. Formas históricas:

do mundo antigo à colonização portuguesa ...........................p. p. 21

1. 3. Especificidades portuguesas na Época Moderna .................... p. 27

1. 3. 1. D. Sebastião: exílio mítico do Desejado .................... p. 28

1. 3. 2. D. Antonio: exílio real do Indesejado ........................ p. 33

1. 3. 3. Casa de Bragança: exílio de Vila Viçosa ................... p. 36

1. 3. 4. União das Coroas Ibéricas: exílio de Portugal? ......... p. 38

\section{Capítulo 2 - Exílio por escrito: história e historiografia}

2. 1. D. João de Castro e Tomé Pinheiro da Veiga:

manifestações lusitanas durante a modernidade ................... p. 40

2. 2. Sebastianismo: genealogia de uma crença ............................ p. 51

\section{Capítulo 3 - Exílio moderno português através das tópicas ovidianas}

3. 1. Ovídio cristianizado: método figural de exegese histórica ................................... p. 57

3. 2. Vergonha e mofinas: o sofrimento como legitimação discursiva ............................ p. 64

3. 3. Entre a esperança e o desalento: a monarquia universal de um D. Sebastião fracassado ........... p. 70

3. 4. Calendário sob controle: alteridade de tempos e espaços p. 76

\section{Considerações finais:}

* Da Valadolide portuguesa ao sebastianismo parisiense p. 83

* Sebastianismo além-fronteiras: exílios conectados? p. 87

Fontes p. 90 
Janus

Universidade de São Paulo

RELATÓRIO DE DEFESA

Aluno: 8138 - $7766122-1 /$ Página 1 de 1

Relatório de defesa pública de Dissertação do(a) Senhor(a) Bruno Romano Rodrigues no Programa: História Social, do(a) Faculdade de Filosofia, Letras e Ciências Humanas da Universidade de São Paulo.

Aos 12 dias do mês de fevereiro de 2015, no(a) Sala de Professores realizou-se a Defesa da Dissertação do(a) Senhor(a) Bruno Romano Rodrigues, apresentada para a obtenção do título de Mestre intitulada:

"Exílios portugueses durante a União das Coroas Ibéricas (1604-1605)"

Após declarada aberta a sessão, o(a) Sr(a) Presidente passa a palavra ao candidato para exposição e a seguir aos examinadores para as devidas arguições que se desenvolvem nos termos regimentais. Em seguida, a Comissão Julgadora proclama o resultado:

$\begin{array}{llll}\text { Nome dos Participantes da Banca } & \text { Função } & \text { Sigla da CPG } & \text { Resultado } \\ \text { Ana Paula Torres Megiani } & \text { Presidente } & \text { FFLCH - USP } & \text { Aprovado } \\ \text { Luís Filipe Silverio Lima } & \text { Titular } & \text { UNIFESP - Externo } & \text { Aprovado } \\ \text { Sérgio Alcides Pereira do Amaral } & \text { Titular } & \text { UFMG - Externo } & \text { Aprovado }\end{array}$

Resultado Final: Aprovado

Parecer da Comissão Julgadora *

A banca aprova a dissertação e ressalta a qualidade da escrita.

Eu, Aline Nogueira Marques Nicolau lavrei o presente relatório, que assino juntamente com os(ą) Senhores(as) examinadores. São Paulo, aos 12 dias do mês de fevereiro de 2015.

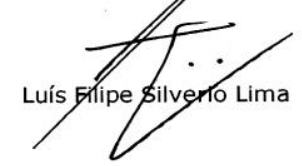

$$
\text { Lnhl }
$$

Sérgio Alcides Pereira do Amaral

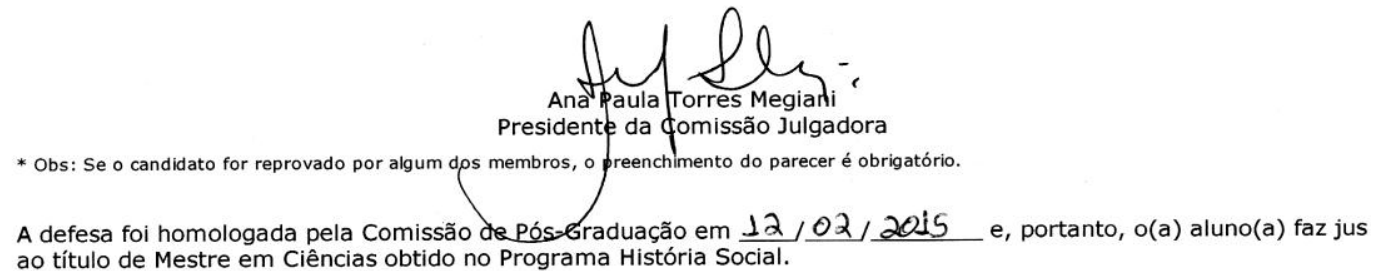
ao título de Mestre em Ciências obtido no Programa História Social.

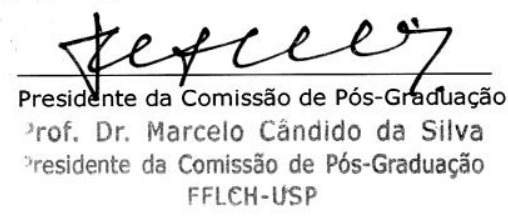




\section{Agradecimentos}

Esta dissertação de mestrado não teria sido possível sem o apoio de pessoas queridas. Em primeiro lugar, agradeço à minha mãe, Regina Benigno Romano, sem a qual nada existiria. A Hildon Vital de Melo, devo os préstimos de uma amizade sincera. Recordo aqui outros caros amigos, como Lucas Palma Mistrello, Renato Akio Yamaguchi, Fábio de Oliveira Abate e Maurício Antunes. A Clara Rodrigues Couto, agradeço, entre outras coisas, o profundo companheirismo. Minha eterna gratidão também a todo corpo docente do curso de História da Universidade Federal de São Paulo (UNIFESP). A Ana Paula Torres Megiani, minha orientadora, devo a acolhida em solo "estrangeiro". Posso dizer, sem risco de engano, que sua generosidade e atenção possibilitaram a feitura das mal traçadas linhas que se seguem. Por fim, e não menos importante, agradeço à FAPESP pela bolsa concedida no período de 2012 a 2014. 


\section{Resumo}

A presente pesquisa reflete sobre o exílio de letrados portugueses coetâneos durante o espaço temporal que a historiografia convencionou chamar de União das Coroas Ibéricas (1580-1640). Para isso, analisam-se as obras de D. João de Castro (Lisboa, Portugal 1550? - Paris, França 1628?), intitulada Aurora (1604-1605), e de Thomé Pinheiro da Veiga (Coimbra, Portugal 1571? - ?, 1656?), chamada Fastigimia (1604-1605), no intuito de apreender o impacto das experiências vividas por cada um deles nas cidades de Paris, na França, e Valadolide, na Espanha, respectivamente. O estudo se pauta no cotejamento das fontes com as tópicas criadas, na Antiguidade, pelo poeta Ovídio (Sulmo/Sulmona, na atual Itália 43 a.C. - Tomis/Constança, na atual Romênia, 17 ou 18 d.C.). Estabelecendo continuidade com a tradição humanista lusitana, mostra-se como D. João de Castro se valeu da funcionalização da memória por meio de figuras míticas ou históricas, da caracterização disfórica da vida no estrangeiro, e, por fim, da constante oscilação entre esperança e desalento. Thomé Pinheiro da Veiga, por sua vez, manejou, em termos literários, a consciência do tempo e do espaço. Diante deste quadro, conclui-se que o exílio de Castro constituiu uma penitência escatológica de caráter individual e coletivo, enquanto o experienciado por Veiga se pautou por sistemáticas comparações entre dois reinos da Península Ibérica.

Palavras chave: Exílio, União das Coroas Ibéricas, Sebastianismo, D. João de Castro, Thomé Pinheiro da Veiga. 


\begin{abstract}
This current study thinks over the portuguese scholars exiled during the time period called by historiography as the Union of Iberian Crowns (1580-1640). For this purpose we will examine two literary works: D. João de Castro's (Lisbon, Portugal 1550? - Paris, France 1628?) Aurora (1604-1605), and Thomé Pinheiro da Veiga's (Coimbra, Portugal 1570 - ? 1656) Fastigimia (1608-1609?), to learn about their experiences, lived by each one, in Paris, France, and Valladolid, Spain, respectively. The study is ruled in contrasting this texts against the themes set up in Classical Antiquity, by roman poet Ovid (Sulmo/Sulmona, nowdays Italy 43 BC Tomis/Constanta, nowdays Romania, 17/18 AD). Stating continuity with portuguese renaissance humanism tradition, D. João de Castro seems like to resort the Ovidian topics about implementing the memory through mithologycal or historical characters, through marking a twisted foreign life, and, a steady oscillation between hope and discincentive. Thomé Pinheiro da Veiga, by himself, handled, in litteraly terms, a strict awareness about time and space. Keeping this in mind, we can conclude that Castro's exile build an eschatological penance with individual and collective nature, while Veiga's stands by a methodical comparison amog the two kingdons of Iberian Peninsula.
\end{abstract}

Key Words: Exile, Iberian Union, Sebastianism, D. João de Castro, Thomé Pinheiro da Veiga. 
À memória de Regina Benigno Romano e dos sabe-se lá quantos Manuéis Maria Romano que existiram no mundo. 
Se havia alguém inofensivo naquele tempo, era o envelhecido e desiludido Coronel Aureliano Buendía, que pouco a pouco fora perdendo todo o contato com a realidade da nação. Fechado na sua oficina, a sua única relação com o resto do mundo era o comércio de peixinhos de ouro [...] O falatório público de que não queria mais saber da situação do país porque estava ficando rico com a oficina provocou as gargalhadas de Úrsula, quando chegou aos seus ouvidos. Com o seu incrível senso prático, ela não podia entender o comércio do coronel, que trocava os peixinhos por moedas de ouro, e em seguida transformava as moedas de ouro em peixinhos, e assim sucessivamente, de modo que tinha que trabalhar cada vez mais à medida que vendia, para satisfazer um círculo vicioso exasperante.

Gabriel Garcia Márquez,

Cem anos de Solidão.

\section{Desterro}

Já me não amas? Basta! Irei, triste, e exilado Do meu primeiro amor para outro amor, sozinho. Adeus, carne cheirosa! Adeus, primeiro ninho Do meu delírio! Adeus, belo corpo adorado!

Em ti, como num vale, adormeci deitado, No meu sonho de amor, em meão do caminho... Beijo-te inda uma vez, num último carinho, Como quem vai sair da pátria desterrado...

Adeus, corpo gentil, pátria do meu desejo! Berço em que se emplumou o meu primeiro idílio, Terra em que floresceu o meu primeiro beijo!

Adeus! Esse outro amor há de amargar-me tanto Como o pão que se come entre estranhos, no exílio, Amassado como fel e embebido de pranto...

Olavo Bilac,

Poesias. 


\section{Apresentação}

A dissertação está divida em três capítulos. O primeiro, "Exílio(s): fenômeno multifacetado", perfaz um caminho que vai do impacto existencial à sistemática utilização do degredo no processo colonizador do Novo Mundo. Tendo em conta o gigantismo do assunto, procurou-se atentar para as especificidades portuguesas durante a modernidade, o que resulta, entre outras coisas, na releitura de dois importantes personagens de fins dos quinhentos. Nas biografias de D. Sebastião e D. Antonio é possível ver, de maneira respectiva, a formulação de uma espécie de exílio "mítico", visto que o Desejado voltaria de seu longo desterro na África; e de outro, quiçá mais palpável, decorrente da intensa perseguição deflagrada por Filipe II ao então candidato ao trono. Além deles, a Casa de Bragança, grande força política do período, parece ter conscientemente optado pelo refúgio no interior de Portugal, mais especificamente em Vila Viçosa. Por fim, faz-se menção ao fato de amiúde se ter representado o período da União das Coroas ibéricas como exílio de uma pátria sob o julgo estrangeiro.

O segundo capítulo, "Exílio por escrito", matiza a temática nas trajetórias e obras dos lusitanos D. João de Castro e Thomé Pinheiro da Veiga. Além disso, julgouse por bem tecer algumas considerações sobre o histórico do debate em torno do sebastianismo, já que sua fundação é consensualmente atribuída ao fidalgo que viveu grande parte da vida adulta em Paris.

No último capítulo, "Exílio moderno português através das tópicas ovidianas", identifica-se na obra de Castro três "lugares comuns". O primeiro diz respeito à emulação de personagens, míticos e/ou históricos, no intuito de legitimar exegeses comprometidas, acima de tudo, com a ideia cristã de redenção. O segundo enquadra as supostas dificuldades materiais enquanto argumento de legitimação literária, recurso que fabrica o sofrimento como dispositivo catalisador das incongruências do letrado com a mundividência do local onde escrevia, a França. $\mathrm{O}$ terceiro consiste basicamente na oscilação entre esperança e desalento, tensão expressa na expectativa pelo advento da monarquia universal versus o desaparecimento de D. Sebastião, em 1578, ou o esquartejamento de um falso D. Sebastião, o de Veneza, a mando dos castelhanos, nos primeiros anos dos seiscentos. Na obra de Veiga, por fim, se infere a utilização de apenas uma tópica: a que exprime o controle do tempo e do espaço no intuito de compor uma narrativa marcada pela noção de alteridade entre Portugal e Espanha. 


\section{Introdução: Penso, logo exílio}

Estar longe e, ao mesmo tempo, estar perto. Eis o dilema colocado no horizonte dos homens e mulheres que, em diferentes épocas e circunstâncias, se viram distantes de seus lugares de nascimento e criação. Os contemporâneos chamam isso de exílio e geralmente o associam aos acontecimentos que chacoalharam grande parte do mundo durante o breve século XX, como diria Eric Hobsbawm ${ }^{1}$. Mas o que é, afinal de contas, o exílio? Num primeiro momento, ele pode ser "a vida levada fora da ordem habitual", o desfecho ou início de uma "experiência de padecimento", ou ainda uma "terra" que é "a ausência de terra dos que têm terra", entre outras definições. O paradoxo que logra sintetiza-lo reside no fato do desterrado não pertencer inteiramente nem ao mundo que deixou para trás nem à cultura em que vivencia sua proscrição. Híbrido, duplo, dividido entre memórias e incertezas. É a partir desta dicotomia que se pode falar num eterno estrangeiro que parte "de" e "para" algum lugar, duplicando espaços em relação aos quais ele sempre estará ausente e presente ao mesmo tempo 5 .

De forma didática, a definição comumente aceita é a de mudança ou deslocamento de uma "unidade de preferência"6 que abrange desde a cidade natal até noções comunitárias mais amplas tais como Reino, Estado e Nação. Para além da distância física, estudos mais recentes chamam atenção para a "condição produtiva"7 e o estado "psicológico" 8 que caracterizam as mais diversas formas históricas de banimento. Contudo, a esta suposta unicidade responsável pela existência de uma literatura específica pode levantar-se a ressalva de que, levada ao extremo, ela estaria privilegiando um "encontro" até certo ponto artificial, visto que a variedade de autores e de tipos documentais (como diários, tratados, cartas e outros gêneros mais, manuscritos ou impressos) pode trazer para primeiro plano comparações desgarradas dos contextos sociais que geram e absorvem o fenômeno do exílio. Válido apenas em parte, o enfoque

\footnotetext{
${ }^{1}$ HOBSBAWM, E. Era dos Extremos: o breve século XX (1914-1991). Trad. São Paulo: Companhia das Letras, 1995.

${ }^{2}$ SAID, E. Reflexões sobre o exílio e outros ensaios. Trad. São Paulo: Companhia das Letras, 2003, p. 60.

${ }^{3}$ VIDAL, P. A história em seus restos: literatura e exílio no Cone Sul. São Paulo:Annablume,2004, p. 51.

${ }^{4}$ MONTANÉZ, A. P. Vozes do Exílio e suas manifestações nas narrativas de Julio Cortázar e Marta Traba. Londrina: Eduel, p. 18.

5 ANDRÉ, C. A. Mal de Ausência: o canto do exílio na lírica do humanismo português. Coimbra: Livraria Minerva, 1992, p. 36.

${ }^{6}$ CIELENS, I. Trois functions de l'exil dans les oeuvres de fiction d'Albert Camus: initiation, revolte, conflit d'identité. Uppsala, Acta Vnieersitatis Vpsaliensis, 1985, p. 8.

${ }^{7}$ MONTANÉZ, A. P. Op. cit., p. 182.

${ }^{8}$ ANDRÉ, C. A. Op. cit., p. 20.
} 
na "experiência do infortúnio" como amalgama de um gênero textual corre o risco de arquitetar um pseudo movimento literário que talvez nunca tenha se pensado enquanto tal, fazendo crer que cada autor tenha necessariamente lido e tentado discutir em suas obras as opiniões que o anterior emitira sobre o assunto.

Retomando o sentido original das palavras latinas exilium, exsilium, exsilire e ex salire, prenhes da idéia de "saltar fora", a presente pesquisa preocupa-se com a carga de experiência que o termo exprime e não propriamente com a confecção de um verbete supostamente capaz de elucidar um conceito aplicável a todo e qualquer tempo e espaço, abarcando inclusive mas não totalmente o contexto ibérico do início dos seiscentos. Caminha-se na direção de entendê-lo através da noção de, por muito ou pouco tempo, "estar fora" do lugar de nascimento, onde o ser humano, via de regra, assimila os parâmetros de sociabilidade que carregará para o resto da vida. Neste sentido, desloca-se o centro de gravidade de obras já conhecidas da historiografia para um evento tido, até o presente momento, quase como detalhe ou, no melhor dos casos, mera curiosidade. Identificá-lo, numa concepção lata, como parte ativa de uma biografia significa ultrapassar os julgamentos de ordem moral que a ele atribuem caráter positivo ou negativo, a depender das circunstâncias em que ocorre.

Durante a Idade Moderna, na cultura espanhola foi chamado de desterro e, na lusitana, de degredo, punições vinculadas aos condenados por tribunais civis e religiosos que eram mandados para outras partes do reino ou, em casos extremos, para as colônias da América, África e Ásia. Assim como em outros, o debate sobre o assunto, no que tange o período em questão, não consegue se ver livre do fardo da "transição" entre o paradigma religioso e a consolidação do padrão laico. Tendo isso em vista, é procedente falar em exílio durante a modernidade, ou, como crê Amanda Montanéz ${ }^{10}$, ele estaria muito mais ligado à consciência do homem contemporâneo? A nosso ver, se pode identificá-lo, sem grandes problemas, na modernidade luso-espanhola. Só não se pode dizer, com exatidão, se ele resulta da (auto) flagelação religiosa ou das crescentes necessidades coloniais enfrentadas pelas monarquias europeias. A saída mais responsável recomenda um equilíbrio entre as duas motivações, ou uma tensão histórica que ora pende para um lado e ora para outro.

\footnotetext{
${ }^{9}$ QUEIROZ, M. J. de. Os Males da Ausência, ou a Literatura do Exílio. Rio de Janeiro: Topbooks, 1998, p. 17.

${ }^{10}$ MONTANÉZ, A. P. Op. cit., p. 177.
} 
$\mathrm{Na}$ Península Ibérica, muitos foram os deslocamentos em série. Pouco registrados, os mais intensos talvez tenham se dado com a perseguição aos focos de islamismo que paulatinamente se dobravam aos ditames da reconquista cristã ${ }^{11}$. Há que se lembrar também o constante trânsito da população judaica, cada vez mais atingida pelo recrudescimento do anti-semitismo ${ }^{12}$, e, posteriormente, pelo rigor dos respectivos Tribunais do Santo Ofício. Do macro ao micro, o presente estudo propõe reduzir a escala de observação para o nível das trajetórias de exilados portugueses durante o início dos seiscentos. De antemão, pode-se dizer que a distância não deve ser entendida como alheamento, pois a ausência física não implica necessariamente o rompimento dos referenciais culturais a partir dos quais se aprende a atribuir sentido às coisas e ao mundo. Deste recorte temático-temporal surgem, pois, as obras A Aurora da Quinta Monarquia (1604-1605), de D. João de Castro, e Fastigimia (1604-1605), também chamada de Fastiginia, de Thomé Pinheiro da Veiga, escritas por lusitanos estabelecidos na França e na Espanha, respectivamente.

Para "restituir o discurso político às suas condições sociais" 13 , é mister atentar para as relações aparentemente desconexas que colocam frente a frente Valadolide e Paris, o ambiente aristocrático de Veiga e as supostas dificuldades financeiras de Castro, e, por fim, a corte castelhana e o sebastianismo. Por óbvio que pareça, o "ser" português em terras estrangeiras requer uma análise pautada nas experiências adquiridas fora de Portugal, na vivência que contribuiu para a formação de padrões de escrita em muitos aspectos similares ao que se convencionou chamar de literatura de exílio, gênero textual fundado, na Antiguidade, pelo poeta Ovídio. Contudo, ao contrário da adesão pública que muitos letrados, daquela e de outras épocas, fizeram das tópicas ovidianas, no presente caso não se tratam de obras sobre, mas de obras no exílio ${ }^{14}$. Isto quer dizer que, à primeira vista, ambos passam ao largo do tema, não o abordando de modo explícito. Mas, além disso, interessa destacar que, tanto pra um quanto pra outro, a escrita é uma consequência direta do exílio. Sobretudo na obra de Castro, já que todo o edifício teórico que sustenta o sebastianismo se baseia em tradições proféticas e, fisicamente

\footnotetext{
${ }^{11}$ Cf. Passim. RUCQUOI, A. História Medieval da Península Ibérica. Trad. Lisboa: Estampa, 1995.

12 MORENO, H. B. Marginalidade e conflitos sociais em Portugal nos séculos XIV e XV. Lisboa: Presença, 1985, pp. 79-117.

${ }_{13}$ CURTO, D. R. O Discurso Político em Portugal. 1600-1650. Lisboa: CEHCP, 1988, p. 73.

${ }^{14}$ O exílio passa a ser um evento controlado, em bases cronológicas, por meio do "antes" e do "depois", mesmo que as fontes não revelem o inteiro teor do "durante". Longe, portanto, de entendê-lo como dado externo, das representações que os próprios autores fazem de si decorrem elementos que ajudam a embasar alguns de seus julgamentos sobre o poder constituído.
} 
falando, na consulta a livros que só estavam disponíveis nas bibliotecas e circuitos letrados de Paris e, em menor grau, de Veneza.

A respeito do mesmo personagem, João Carlos Serafim propôs uma "história da cultura dos portugueses no exílio" 15 , muito embora tenha reconhecido a dificuldade de apreender o tema num fidalgo que parece ter vivido "essencialmente em função do passado", razão pela qual preteriu "qualquer tipo de discurso sobre o presente que preferia esquecer"16. Em termos de periodização, o tal "presente a ser esquecido" divide-se em dois momentos. O primeiro, itinerante, vai de 1580, quando, com cerca de trinta anos, aderiu ao partido de D. Antonio, a 1601, já com mais de cinquenta, quando chegou a Paris após breve passagem por Portugal, única ocasião em que interrompeu seu desterro. A segunda etapa compreende o período que vai até 1628, provável ano de sua morte, e se caracteriza pela sedentarização em território francês. Ali, entre outras coisas, Castro "concretiza" o interesse pelo mundo das letras que havia perdido desde a fuga de Évora, ainda na juventude. Vale lembrar, por fim, que não escreveu uma única linha em Portugal. Tudo, absolutamente tudo, foi produzido no exterior.

Por maior reconhecimento que se possa dar aos padrões retóricos que traduzem um sentimento em palavras, formatando, ao cabo, um discurso, ainda assim uma desconfiança persiste. Faz diferença refletir sobre uma determinada realidade estando "fora" dela, e, neste caso, como deve ser entendido o "estar fora"? Em outras palavras, se, de fato, os letrados não estavam de corpo presente na genésica terra, não se pode negar que, por diferentes maneiras, permaneceram vinculados a Portugal num momento tão particular. O cenário do pós Alcácer Quibir chama atenção pela riqueza de possibilidades (desde que se considerem os limites do Antigo Regime) oferecidas a um reino que tentava se recuperar de uma tragédia sem precedentes; e que, em virtude disso, se via aturdido com choques cada vez mais intensos entre correntes antagônicas que começavam a disputar os mesmos espaços de poder. A morte de D. Henrique, segundo Fernando Bouza, proporcionou a "súbita ampliação da arena política"17.

\footnotetext{
${ }^{15}$ SERAFIM, J. C. G. D. João de Castro, o 'sebastianista'. Meandros de vida, e razões de obra. Porto: Faculdade de Letras da Universidade do Porto, 2004, Tomo I, p. 4.

${ }^{16}$ Idem. Tomo II, p. 373.

17 ÁlVAREZ, F. B. "De las Alteraciones de Beja (1593) a la Revuelta Lisboeta dos Ingleses (1596). Lucha Politica en el ultimo Portugal del primer Felipe”. Studia Histórica - História Moderna, s/1, vol. 17, 1997, p. 101.
} 


\section{Capítulo 1 - Exílio: fenômeno multifacetado}

Aqui somos peregrinos, e nossa vida é longo desterro [...] E cumpre trazer sempre impressa n'alma a lembrança de nosso desterro e peregrinação, para andarmos de alevanto nas cousas do mundo, sem fazermos dele fundamento [...] Tristes daqueles que se têm por moradores e naturais da terra, e não por peregrinos e estrangeiros.

Frei Heitor Pinto, Diálogo da Tribulação.

\section{1. Sentidos existenciais: expressões de um sentimento}

Há aproximadamente quatro mil anos, o egípcio Sinuhe dizia ter sido conduzido para longe da família contra a vontade de seu "coração". A partir de então, o tema marcaria presença em diferentes culturas e tradições. A visão cristã diz que Adão e Eva são os primeiros desterrados, após terem sido expulsos do Paraíso. "Exilada do céu"18, a humanidade passou a viver tal qual povo estrangeiro. No Gênesis, no Êxodo e no Salmo 136, o mito que inaugura o povoamento do universo buscava condicionar a essência humana à "pátria celestial". O exílio ainda se daria a conhecer em eventos bíblicos como a provação de Abraão e o castigo a Jeremias, podendo aparecer, noutras passagens, com os sentidos de desalento, esperança, redenção, santidade e até como esteio da longeva e polivalente idéia de "povo eleito". Dentre outras mais importantes, esta pode ser uma via de acesso para os conflitos político-religiosos do Oriente Médio, no sentido de que árabes e judeus discutem até hoje a quem pertence a terra que ambos os lados gostariam de ter exclusividade. Em outras religiões, vale dizer, a tópica também opera na codificação dos mistérios da vida, a exemplo de um Maomé que funda no estrangeiro o Estado Islâmico, e da renúncia budista ao mundo material.

Dispositivo de controle da vida política, na Grécia Antiga atribui-se ao ostracismo a perda de direitos e do que se considerava a plena cidadania democrática. Não menos importante em Roma, o tema ali se dividiria em duas correntes de pensamento. A primeira, delineada por Sêneca durante sua estadia na Córsega, esvazia o exílio de qualquer conteúdo místico, já que, segundo o próprio, nenhum lugar do mundo poderia soar estranho ao sábio homem que cultivasse suas virtudes. A segunda, fundada pela pena de um Ovídio condenado a residir em Tomos, atual na Romênia, inaugura os célebres "lugares-comuns" que caracterizariam um tipo específico de literatura dali por

\footnotetext{
${ }^{18}$ CHEVALIER, J.; GHEERBRANT, A. Dicionário dos símbolos. Trad. Rio de Janeiro: José Olympio Editora, 1988, p. 403.
} 
diante. É sabidamente regida pelo paradigma ovidiano que no medievo a tópica esteve muitas vezes ligada a questões amorosas, como a saudade do cavaleiro pela amada que se encontrava distante ${ }^{19}$. O que parece curioso, e esta é só uma desconfiança, é o fato do tema paulatinamente sair da esfera subjetiva à medida que a Europa experimenta uma progressiva centralização das monarquias nacionais, quando a figura do rei se protagoniza perante outras tradicionais instâncias de poder.

Em fins do século XVII, o médico francês Johannes Hoffer empreendeu estudos no sentido de viabilizar a melhora clínica de pacientes de origem suíça acometidos de tristeza aguda após terem deixado temporariamente as cidades em que haviam nascido, geralmente localizadas em sítios montanhosos. Suspeitava-se que a estadia em baixas altitudes pudesse ocasionar a obsessiva vontade pelo retorno, desejo que se mostraria o único remédio capaz de curar a dor que em casos mais graves deixava os doentes à beira da morte, segundo a tese de doutorado por ele defendida na Universidade da Basiléia. A moléstia entraria para a terminologia médica com o nome de "mal de exílio", sendo chamada também de "mal de ausência". Para surpresa do estudioso, a nostalgia extrapolaria suas amostragens, se fazendo manifestar em soldados e marinheiros naturais da Bretanha e da Borgonha e ainda nos refugiados na longínqua Groelândia. Incorporada ao receituário, a patologia se manteria na literatura especializada até meados dos Oitocentos, entrando em definitivo descrédito acadêmico com o advento da ciência positiva ${ }^{20}$.

Na Península Ibérica, o "mal de ausência" encontra guarida em palavras como saudade, morrina e soledad. No caso português, o primeiro dos termos surge como destacado componente identitário, sintetizando o lamento pelo monarca sumido em 1578, a perda da autonomia política dois anos mais tarde e a nostalgia das conquistas ultramarinas que pouco a pouco ficavam para trás. Mensurada por suas consequências, a saudade é, de acordo com Eduardo Lourenço, o "coração de todas as ausências"21. Para além das explicações "internas", na obra de D. João de Castro, relevante teórico sebastianista, ela ganha materialidade no longo exílio que o fidalgo experimenta em Paris, quando então busca pensar sua própria trajetória em paralelo com o destino pátrio. Assim, potencializa-se a dramaticidade de um fenômeno social que também se

\footnotetext{
${ }^{19}$ Cf. TAVANI, G. A poesia lírica galego-portuguesa. Editorial Comunicação. s/l: s/ed., 1990; BREA, M., GRADÍN, P. L. A Cantiga de Amigo. Salamanca: Edições Xerais, 1998; ANDRÉ, C. A. Op. cit., pp. 139-145.

${ }^{20}$ QUEIROZ, M. J. Op. cit., p. 34 e 37.

${ }^{21}$ LOURENÇO, E. Mitologia da Saudade: seguido de Portugal como destino. São Paulo: Companhia das Letras, 1999, p. 15.
} 
vale da agonia de um reino cada vez mais exilado de si na medida em que as "gentes partiam" à procura de "outros", e parecia haver muitos "outros" espalhados pelo mundo. Se se trata realmente de um típico sentimento lusitano, a saudade experimentada no exílio é o lamento pelo que não é português; é, por fim, descobrir-se triste com quase tudo que há no universo.

Figuras de vulto da cultura portuguesa mereceram estudos centrados no desterro que de uma maneira ou de outra impactaram biografias bem conhecidas da plateia acadêmica e até do público em geral. A mais notável delas é, sem dúvida, a do Padre Antonio Vieira (1608-1697), que no Sermão de Nossa Senhora da Conceição chega a comparar o exílio à sepultura ${ }^{22}$. Na lista dos nomes menos conhecidos há o de $\mathrm{D}$. Miguel da Silva (1480-1558), que ficaria conhecido por figurar na dedicatória do célebre Libro del cortegiano, de Castiglione. Internamente, seu prestígio só começaria a decair após a acusação de desobediência ao rei. Conta-se que D. João III esperava a ascensão de seu irmão ao posto de Cardeal quando recebeu a informação que D. Miguel fora agraciado com o título após uma fuga sigilosa com destino a Roma, onde dali em diante manifestaria "escassos sentimentos de saudade" 23 e "desapego da pátria"24. Irado, o soberano decreta a desnaturação do Bispo de Viseu, acrescida da perda de qualquer outro direito ou benefício, sob a alegação de que o ex-súdito havia transposto as fronteiras sem a devida permissão e ainda por cima em poder de segredos de Estado. A hipótese de Sérgio Alcides é a de que a supressão do estatuto de natural do reino ultrapassa o "leal amor" da típica relação medieval entre vassalo e suserano para estabelecer vínculos mais abstratos com um dado território elevado à condição de "pessoa mística"25.

$\mathrm{Na}$ "cidade eterna", D. Miguel pôde conviver com o compatriota Diogo Pires (1517-1599? $)^{26}$, poeta de ascendência judaica que chegara a estudar na Universidade de Salamanca antes de seguir para o exílio "real, concreto e definitivo"27 causado pela perseguição inquisitorial, muito embora não tenha havido qualquer condenação explícita por parte do Santo Ofício. O roteiro de fuga passa por Inglaterra, Países Baixos, Paris e

\footnotetext{
${ }^{22}$ Cf. ARAúuO, J. G. Antonio Vieira, entre o Degredo e a Pátria: Percursos de Saudades. Coimbra: Universidade de Coimbra, Faculdade de Letras, 2010.

${ }^{23}$ ANDRÉ, C. A. Mal de Ausência. Op. cit., p. 269.

${ }^{24}$ Idem, p. 441.

25 AMARAL, S. A. P. do. "D. Miguel da Silva, o cortesão desnaturado por D. João III”. In: SOUZA, L. de M. e; FURTADO, J. F.; BICALHO, M. F. Op. cit., pp. 438-439.

${ }^{26}$ ANDRÉ, C. A. Um Judeu no Desterro. Diogo Pires e a memória de Portugal. Coimbra: Instituto Nacional de Investigação Científica, 1992, p. 91 e 95.

${ }^{27}$ Idem. Mal de Ausência. Op. cit., p. 394.
} 
Itália. Ali cruza o Mar Adriático em direção a Ragusa, na Croácia, onde desfruta de ampla liberdade civil e religiosa. É curioso saber que as mais de quatro décadas de exílio do rebatizado Isaías Cohen expõem uma indistinta saudade dos lugares pelos quais passara, incluindo aí o período de estudos na Espanha ${ }^{28}$. Contraditória ao ódio nutrido pelos Reis Católicos, a nostalgia de Salamanca aponta para a existência de um exílio "desnacionalizado" que pode relativizar suas apologias do aqueduto de Évora, o qual nunca chegou a ver concluído, e da Universidade de Coimbra que jamais conheceu, quiçá nem mesmo a cidade. A nosso ver esta noção de reino "aos pedaços", cidade-acidade, intenta compor memórias condicionadas por aspectos míticos da história portuguesa ao invés de narra-las a partir da curta vivência em solo pátrio que as seis décadas de afastamento já poderiam ter apagado de sua mente.

O criptojudeu Manuel Bocarro Francês (1593-1662) também estudou em universidades espanholas antes de publicar obras como Luz Pequena Lunar e Estelífera da Monarquia Lusitana, que conta com a elogiosa carta-prefácio do italiano Galileu Galilei, e a Anacefaleose da Monarquia Lusitana, para ficar nas mais conhecidas. Com a perseguição do Santo Ofício português, refugia-se em Roma e depois em Amsterdã e Hamburgo, quando então assume publicamente a religião de seus antepassados. Daí por diante se faria conhecer na comunidade judaica como Jacob Rosales, nome só preterido ao original quando se dirigia a autoridades públicas ou a plateias de outras religiões. Além do reconhecimento nas áreas da medicina e astronomia, o exílio em terras alemãs revela a inoperância dos padrões de nacionalidade, visto que, a despeito da querela entre sebastianismo e messianismo brigantino, a colaboração com os Habsburgo fez de Bocarro um autêntico representante do partido espanhol em detrimento da causa portuguesa e até dos interesses sefardistas ali estabelecidos ${ }^{29}$. Na segunda metade dos seiscentos outro médico se veria desterrado, tendo o estigma da proscrição cumprida no Brasil agido como claro impeditivo para a nobilitação de Salvador Moreira na Ordem de Avis após o retorno a Lisboa, a isso somado o que o Antigo Regime chamava de "defeitos manuais" 30 .

\footnotetext{
${ }^{28}$ Idem, p. 409; Idem. Um Judeu no Desterro. Op. cit., p. 37 e 95.

29 Cf. CAROLINO, L. M. "Introdução". In: FRANCÊS, M. B. Luz pequena lunar e estelífera da Monarquia Lusitana. Coleção História da Ciência - Série Documentos da Ciência. Rio de Janeiro: MAST, 2006, p. 19.

${ }^{30}$ DUTRA, F. A. "Salvador Moreira, cirurgião e degredado no Maranhão, século XVII". In: Revista Textos de História, vol. 6, nº 1 e 2, 1998, pp. 101-114.
} 
Para o inconfidente mineiro Cláudio Manuel da Costa (1729-1789), o exílio se centraria no "conflito entre a persona poética do autor e a paisagem ao redor" 31 . Coração da região aurífera na América portuguesa, as Minas Gerais se tornariam a antítese do locus amoenus de tradição virgiliana, a elas sendo imputado o rompimento dos laços entre "pastor" e "paisagem" 32 . No âmbito biográfico, o retorno de Coimbra, onde Costa passa parte da juventude aperfeiçoando seus estudos, faz com que o autor se sinta "fora de lugar", desterrado, como dirá mais tarde Sérgio Buarque de Holanda sobre o Brasil, no seio de sua própria terra. O paradoxo "criação" versus "formação" expõe a fragilidade dos preceitos do arcadismo europeu quando transpostos para a realidade socioeconômica de uma colônia cada vez mais asfixiada pela rigorosa política fiscal metropolitana. Em termos líricos, a solução do impasse só se daria com a substituição do tal locus amoenus pela tópica ovidiana do exílio. Tradicionalmente direcionada ao estrangeiro, neste caso ela volta-se contra o solo pátrio. As Minas Gerais equivaleriam, no plano retórico, ao Ponto Euxino lugubremente descrito por Ovídio, muito embora sejam estas Minas a origem e não o destino de um poeta estranhamente exilado no lugar em que nascera.

Radicado em Macau, em fins dos oitocentos, Camilo Pessanha (1867-1926) teria dividido sua poesia em duas "atitudes líricas". Herdeira dos cânones literários, a primeira delas é a "angústia nostálgica",33 que instrumentaliza a sensação de perda e desenraizamento e pode comumente se associar ao langor, termo utilizado originalmente para exprimir o afastamento entre Deus e seus seguidores. A segunda é a "ação dissolvente da melancolia"34, estágio em que se acentua a postura de uma "espera sem esperança" ${ }^{\text {35 }}$. Do ponto de vista estético, o exílio passa a representar a condição humana e denuncia a inoperância de uma memória cristã que já não consegue explicar o mundo com a tanta eficiência. Nesta chave de leitura pátria e degredo se equivalem em grau de estranhamento, fazendo com que Pessanha evite reivindicar suas reminiscências de Portugal em contraposição a eventuais dificuldades de adaptação na China. A superação da nostalgia acaba por implodir o paradigma ovidiano que não poderia

\footnotetext{
31 AMARAL, S. A. P. do. Estes Penhascos: Cláudio Manuel da Costa e a Paisagem das Minas (17531773). São Paulo: Hucitec, 2003, p. 13.

32 Idem, p. 253.

${ }^{33}$ FRANCHETTI, P. Nostalgia, Exílio e Melancolia: Leituras de Camilo Pessanha. São Paulo: Editora da Universidade de São Paulo, 2001, p. 103.

${ }^{34}$ Ibidem.

${ }^{35}$ Idem, p. 87.
} 
continuar subsistindo "sem origem" a ser lembrada e "sem desejo de retorno" $"$. Em síntese, o cético exílio de um único indivíduo passa a ser o de todos uma vez que o lugar de nascimento simbolicamente não existe mais.

Ainda na esfera dos estudos de caso, a distância do genésico solo pode ser vista como algo "benéfico" nas trajetórias dos judeus portugueses Isaac Abravanel e seu filho Yehudá, conhecido como Leão Hebreu, que em fins dos quatrocentos conheceram notoriedade pública com atividades literárias desenvolvidas no estrangeiro ${ }^{37}$. No começo do século seguinte o também português Aires Barbosa teria sido um dos que "pouco se deixou dominar pela saudade" 38 , seguido por nomes como André de Resende e Aquiles Estaço. Profícua foi também a estadia de Voltaire na Inglaterra, onde teria desfrutado de liberdade político-religiosa para aprofundar seus estudos filosóficos, assim como o perambular do francês Victor Hugo, que em certos momentos afirmou gostar do exílio ${ }^{39}$. Algo semelhante se passará com o escritor paraguaio Augusto Roa Bastos ao narrar suas "experiências enriquecedoras" durante o período em que se radicou em Buenos Aires, na Argentina, em virtude da perseguição do regime militar comandado em seu país por Alfredo Stoessner ${ }^{40}$. Na trilha de Bastos, a literatura contemporânea dos exilados latino-americanos se apresentaria enquanto "resto" da resistência aos regimes autoritários que se disseminaram pelo continente ao longo da segunda metade dos novecentos. Deixando de explorar o fracasso político com auto complacência, o argentino Júlio Cortázar também pode ser considerado um dos que concebeu o exílio como espaço de reflexão e produtividade intelectual ${ }^{41}$.

Antes disso, a América Latina já havia se tornado tema de outros grandes intelectuais autóctones que se valeram da idéia de exílio mesmo nunca tendo sofrido algum tipo de banimento. Nesta perspectiva se coloca o mote concebido originalmente por Jorge Luís Borges em El tamanho de mi esperanza (1926) e conhecido do público nacional na pena de um Sérgio Buarque de Holanda que em Raízes do Brasil (1936) afirmava sermos "ainda hoje uns desterrados em nossa terra". No entender do historiador brasileiro, o desterro é de quem fica, do indivíduo que vive em sua própria "terra" de forma parcial, como se o país não tivesse sido organizado politica e socialmente para atender suas necessidades. Há que se lembrar ainda da vigorosa recusa

\footnotetext{
${ }^{36}$ Idem, p. 150.

${ }^{37}$ QUEIROZ, M. J. Op. cit., pp. 125-134.

${ }^{38}$ ANDRÉ, C. A. Mal de Ausência. Op. cit., p. 261.

${ }^{39}$ QUEIROZ, M. J. Op. cit., p. 277.

${ }^{40}$ GUILLÉN, C. O Sol dos Desterrados: Literatura e Exílio. Lisboa: Editorial Teorema, 2005, p. 137.

${ }^{41}$ VIDAL, P. Op. cit., p. 41, 46 e 47.
} 
ao projeto de Estado-Nação subjacente ao Pueblo Enfermo (1909), clássico da literatura boliviana escrito por Alcides Arguedas ${ }^{42}$. Tal maneira de pensar parece ter se manifestado em outros tempos, como no caso do letrado lusitano Inácio de Morais que, durante a segunda metade do século XVI, escreveu em homenagem a seus compatriotas residentes na Espanha ${ }^{43}$. Aliás, são deste período os versos de um anônimo que dizia ficar "a pátria em exílio quando os companheiros partem; e enquanto estiverem tão longe de mim, eu serei um exilado" 44 .

Expoente da corrente que prioriza o viés geográfico, Edward Said foi um dos que experienciou e refletiu sobre a "fratura incurável entre um ser humano e um lugar natal" ${ }^{45}$, pondo em destaque o caráter massivo e a negação da identidade que caracterizam o fenômeno nos dias de hoje. Tendo por pano de fundo a desconstrução dos estereótipos por meio dos quais o mundo ocidental interpretou historicamente o Oriente, o paradigma do Estado-Nação consegue homogeneizar a "dor mutiladora da separação"46 apenas e tão somente como consequência do afastamento de determinado membro dum grupo mais amplo de pessoas. Válida estritamente para a contemporaneidade, a lógica nacionalista pode ser responsável por certos equívocos analíticos quando os debates se dirigem a tempos mais recuados como a modernidade, sobretudo quando se pensa uma Península Ibérica que derrubaria suas monarquias muito mais tarde que o resto da Europa.

De tempos para cá, novas pesquisas apontaram a necessidade de extrapolar a idéia de comunidade pautada exclusivamente por fronteiras territoriais. Do exílio físico ao existencial, no caminho que conecta a tópica latina com a contestação do pertencimento a um único lugar, a interação personagem-ambiente se distende na medida em a busca pelo retorno às origens cede lugar para a insatisfação com a vida humana. Ulisses, para quem a ruptura é superada pelo retorno, e Dom Quixote, cavaleiro que jamais conseguiria estabelecer raízes, podem ilustrar este processo de desencantamento por meio de criações literárias. O aspecto psicológico do chamado "mal-estar no território" 47 acaba por convulsionar o paradigma nacionalista, substituindo-o pelo ser que não se apega a um início nem reivindica destino final que

\footnotetext{
${ }^{42}$ Cf. ARGUEDAS, A. Pueblo Enfermo. La Paz: Libreria Editorial G.U.M., 2008.

43 ANDRÉ, C. A. Mal de Ausência. Op. cit., p. 186 e 215.

${ }^{44}$ Idem, p. 209.

${ }^{45}$ SAID, E. Op. cit., p. 46.

${ }^{46}$ Ibidem.

47 PACHECO, K. A Comunidade em Exílio: Literatura comparada entre Lima Barreto e Roberto Arlt. São Paulo: Annablume, 2013, p. 16.
} 
possa redimir as dores do afastamento. Polissêmico e ambíguo, o exílio pôde aqui dar vazão a alguns dos sentidos existenciais expressos por linhas de força que atravessam os períodos históricos nos quais o fenômeno se manifesta.

\section{2. Formas históricas: do mundo antigo à colonização portuguesa}

Além do ostracismo, na Grécia Antiga utilizava-se o banimento perpétuo e o autoexílio, dependo das circunstâncias. No mundo romano, empregava-se a morte civil através da deportatio, que consistia na perda de direitos civis e bens materiais, e da regalatio, quando o condenado se afastava da comunidade sem prejuízo financeiro. $\mathrm{Na}$ Península itálica pré-renascentista, o exílio podia ser feito dentro de uma mesma cidade ao enviar-se o indesejado para zonas urbanas sob o controle de famílias rivais ao clã político responsável pela expulsão ${ }^{48}$. Já na Idade Moderna, as monarquias europeias adotariam práticas semelhantes. A França se valeu do banimento em situações pontuais, como na exploração do Canadá, Mississipi e Nova Orleans, Brasil e Guiana. A Inglaterra setecentista enviou seus condenados para a América do Norte e em menor grau para a Austrália. No caso holandês, Maurício de Nassau chegou a sugerir às autoridades que enviassem para o nordeste brasileiro todos os detentos aptos a defender os interesses batavos na América do Sul. Na centúria seguinte, a Rússia começaria a punir os transgressores com colônias de trabalho forçado na Sibéria, aproveitada para este fim até a URSS do período stalinista.

Inspirada na tradição jurídica latina, a modernidade ibérica não ficaria de fora deste amplo processo de exclusão, mesmo que oscilando de intensidade de um reino para outro. A Espanha pouco se valeu do desterro para o mundo colonial, exceção feita a Navarra, onde serviu para punir os envolvidos em desordens públicas das mais diversas espécies ${ }^{49}$. No contra fluxo, a justiça espanhola também teve que acolher estrangeiros, vendo-se obrigada a "definir o estatuto administrativo de um exilado",50 dentro dos limites territoriais da Monarquia Católica. Transnacional, a solidariedade religiosa teria inclusive possibilitado a ascensão social de indivíduos de origem francesa

\footnotetext{
${ }^{48}$ ANDRÉ, C. A. Mal de Ausência. Op. cit., p. 34.

49 Cf. ASTIZ, J. R. "El castigo de destierro en la Navarra moderna: el caso de los implicados en desordenes públicos". Revista Espacio, Tiempo y Forma. Série IV, História Moderna, t. 23, 2010.

${ }^{50}$ IBÁÑ̃Z, J. J. R. "Servir segundo a dignidade: exílios políticos e administração real na Monarquia Hispânica (1580-1610)”. In: Raízes do Privilégio: mobilidade social no mundo ibérico, p. 107.
} 
e inglesa então incorporados na malha administrativa do império castelhano. Em termos culturais, havia espaço para comparações de cunho identitário, sobretudo em relação aos vizinhos, retratados como passionais pelo menos desde a publicação da novela cervantina De lo que contó el enamorado portugués. Às representações idiomáticas caricaturais e por vezes jocosas se acrescentariam características como sedução, cortesia, ironia, sutileza, agudeza, valentia e até arrogância ao estereótipo lusitano preconizado pelo Siglo de Oro da literatura espanhola ${ }^{51}$.

Durante a Reconquista Cristã, a exeat de villa condenava o criminoso a sair de sua cidade natal após o pagamento de multa, ficando o mesmo proibido de retornar até o cumprimento da pena ${ }^{52}$. No caso específico de Portugal, a crise política de fins do século XIV é responsável pelo êxodo de parte da velha nobreza que dali por diante constituiria casas nobres em terras espanholas ${ }^{53}$ ao mesmo tempo em que, na contra mão, grupos de castelhanos se estabeleciam em solo luso ${ }^{54}$. Longe de associar a fidelidade política ao local de origem ou à noção de naturalidade, no medievo tais elites nobiliárquicas praticamente desconsideravam as mambembes fronteiras nacionais ${ }^{55}$. Nesta mesma época o reino português conheceria os coutos e homízios, regiões fronteiriças que com o tempo passaram a abrigar criminosos e foragidos da justiça. Batizadas originalmente com o termo latino Cautum, que significa "terra privilegiada", as zonas urbanas onde se desenvolveu esta espécie de exílio interno estiveram quase que totalmente dominadas por famílias nobres ou ordens religiosas, sendo a mais famosa delas a cidade de Castro Marim, fundada em 1421 por carta régia de D. João I.

As práticas de expulsão passariam por diferentes estatutos jurídicos até serem definitivamente eliminadas da legislação portuguesa no começo da década de 1950. Banidos, segundo o Código Filipino, eram os foragidos da justiça. No Código Penal de 1852 o desterro é definido pela exclusão de um dado local enquanto o degredo pelo deslocamento forçado para determinado território do império, esta última penalidade carregando o sentido de proclamação pública de um ato considerado vil. O advento do

\footnotetext{
${ }^{51}$ Cf. PEDROSA, J. M. "El otro portugués: tipos y tópicos en la España de los siglos XVI al XVIII". Revista Iberoamericana, vol. VII, $\mathrm{n}^{\circ}$ 28, 2007.

${ }_{52}$ Cf. CORREIA, E. "A evolução histórica das penas". Boletim da Faculdade de Direito da Universidade de Coimbra. Coimbra, vol. 53, 1977, pp. 54-57.

${ }^{53}$ Cf. MORENO, H. B. "Exilados portugueses em Castela durante a crise dos finais do século XIV (13841388)". In: Idem. Exilados, marginais e contestatários na sociedade portuguesa medieval. Lisboa: Editorial Presença, 1990, pp. 26-56.

${ }^{54}$ Cf. FERNANDES, F. R. "Os exilados castelhanos no reinado de D. Fernando I de Portugal". Revista En la España Medieval, vol. 23, 2000, pp. 101-115.

${ }^{55}$ Cf. Idem. "A nobreza, o rei e a fronteira no medievo peninsular". Revista En la España Medieval, vol. 28, 2005, pp. 155-173.
} 
exílio externo, intercontinental, é um dos desdobramentos das grandes navegações, tendo sido aproveitado durante o Antigo Regime como "mecanismo punitivo de normatização social"56. Num primeiro momento utiliza-se a punição para completar as tripulações embarcadas nas galés, não isentando nem mesmo os estrangeiros residentes em Portugal. Houve também a proscrição inter-colonial, uma espécie de reprodução deformada das medidas de assepsia social empreendidas originalmente na Metrópole. Entre as cidades e vilas da América portuguesa, ou mesmo do Brasil para Angola e Moçambique, este tipo de degredo às avessas também proporcionaria o inusitado refluxo de escravos africanos, cariocas, baianos e mineiros às principais cidades portuguesas como punição por delitos cometidos em terras tupiniquins ${ }^{57}$.

No âmbito do "sistema global de exílio",58, as Índias Orientais associavam o degredo ao serviço militar, inexistindo diferenças significativas entre soldados e colonos antes do casamento com mulheres nativas ou em casos de deserção e conversão ao Isla $^{59}$, respectivamente. No que tange a questões de gênero, as mulheres teriam sido exiladas em decorrência de crimes cometidos no espaço doméstico, talvez o único reservado para a vida social feminina no período ${ }^{60}$. Em termos étnicos, a história comparada do tratamento dispensado à população cigana revela discrepâncias entre um império espanhol que recusa "contaminar" suas colônias e, no caso de português, a intensa perseguição que resultou na sua dispersão por quase todos os territórios ultramarinos $^{61}$. Na cena religiosa o destaque fica por conta dos judeus refugiados em Portugal após a expulsão da Espanha a mando dos Reis Católicos. Pouco tempo depois o frustrado batismo coletivo ordenado pelo monarca lusitano D. Manoel escorraça levas

\footnotetext{
${ }^{56}$ PIERONI, G. Banidos: a Inquisição e a lista dos cristãos-novos condenados a viver no Brasil. Rio de Janeiro: Bertrand Brasil, 2003, p. 36.

${ }^{57}$ Idem. Vadios e ciganos, heréticos e bruxas: os degredados no Brasil-colônia. Rio de Janeiro: Bertrand Brasil-Fundação Biblioteca Nacional, 2000, p. 116.

${ }^{58}$ COATES, T. "O sistema reage à mudança”. Revista Textos de História, vol. 6, no 1-2, 1998, p. 227.

${ }^{59}$ Cf. BOXER, C. O Império marítimo português (1415-1825). Trad. São Paulo: Companhia das Letras, 2002, pp. 309-330; CRUZ, M. A. L. "Degredados e arrenegados portugueses no espaço índico". Revista Textos de História. Op. cit., pp. 169-184; DORÉ, A. Sitiados: os cercos às fortalezas portuguesas na Índia (1498-1622). São Paulo: Alameda, 2010, pp. 199-208.

${ }^{60}$ Cf. AMADO, J. "Crimes domésticos: criminalidade e degredo feminino". Revista Textos de História. Op. cit., pp. 143-168; PANTOJA, S. "A diáspora feminina: degredadas para Angola no século XIX (1865-1898)". Revista Textos de História. Op. cit., pp. 185-210.

${ }^{61}$ Cf. COSTA, E. M. L. da. "O povo cigano e a colonização - Portugal e Espanha, soluções diversas?". Revista Mare Liberum. Lisboa: Comissão Nacional para as Comemorações dos Descobrimentos Portugueses, no 10, 1995, pp. 173-188; Idem. "O povo cigano e o degredo: contributo povoador para o Brasil colônia. Revista Textos de História. Op. cit., pp. 48-49; PIERONI, G. Vadios e ciganos, heréticos e bruxas. Op. cit., p. 111; Idem. "Detestáveis na Metrópole e receados na colônia - os ciganos portugueses degredados para o Brasil”. Revista Varia História (FFLCH), nº 12, 1993.
} 
e mais levas de sefardistas que na América se tornariam essenciais para $o$ desenvolvimento da economia local.

Aqui os degredados teriam sido importantes, dentre outras coisas, para os primeiros contatos com as populações autóctones. Segundo a carta de Pero Vaz de Caminha, os portugueses João de Thomar e Afonso Ribeiro foram os primeiros condenados a fixar residência no Brasil, vindos na armada de Pedro Álvares Cabral em 1500. Quase cinquenta anos depois, Tomé de Souza chegaria à Bahia acompanhado por mais 400 deles. Paulatinamente a colônia brasileira acolheria contingentes cada vez mais volumosos, a ponto de Duarte Coelho, donatário de Pernambuco, e o padre Manuel da Nóbrega, residente em São Paulo, a eles se referirem como "praga" e gente "vil e perversa", respectivamente. Do Rio de Janeiro, Mem de Sá também relataria sua desaprovação com o comportamento de alguns, razão pela qual teria ordenado a construção de um pelourinho na cidade. Neste contexto, Charles Boxer afirma ter havido um dramático aumento da tensão social na colônia, o que só fazia crescer os casos de violência em geral e de assassinatos ${ }^{62}$.

Praticamente todos os grandes centros da América portuguesa receberiam desterrados, inclusive regiões inóspitas como a Amazônia, onde o cumprimento da pena serviu para endossar a precária defesa militar da região norte da colônia ${ }^{63}$. Isso porque as Ordenações Filipinas enumeram nada menos que 90 tipos de crimes puníveis com a proscrição para o Brasil, em "grau elevado de punição" 64 , de um total de 256 infrações civis e heresias religiosas; além das especificações contidas no Regimento dos Degredados (1582). O fato é que no começo da colonização o degredo se responsabilizava pelo estabelecimento da maior parte dos homens brancos nos territórios portugueses situados abaixo da Linha do Equador. Em início dos seiscentos, por exemplo, tal população compunha quase $40 \%$ dos paulistas. Mas aos poucos o estigma da expulsão se diluiria no restante da massa, e com o advento da escravidão de negros africanos sua importância diminuiria ainda mais, inutilizando as teorias que atribuem toda e qualquer mazela social contemporânea a tal fenômeno.

\footnotetext{
${ }^{62}$ BOXER, C. Op. cit., pp. 327-328.

${ }^{63}$ Cf. AMADO, J. "Viajantes involuntários: degredados portugueses para a Amazônia colonial". Revista História, Ciências, Saúde - Manguinhos, vol. VI (suplemento), 2000, pp. 813-832.

${ }^{64}$ PIERONI, G. Os excluídos do Reino: a Inquisição portuguesa e o degredo para o Brasil Colônia. Brasília: Editora Universidade de Brasília, 2006, p. 50.
} 
Baseadas mais em suposições que em sólidas pesquisas documentais, as obras de Paulo Prado, Affonso Ruy, Vicente Tapajós, Roy Nash, Pedro Calmon e Costa Lobo ${ }^{65}$ incorrem no anacronismo de conceber os criminosos da modernidade portuguesa como seres altamente nocivos, não se dando conta de que à época a noção de crime pautava-se numa moralidade católica que enquanto "unidade social estabelecida" de heréticas práticas como bigamia, sodomia, sedução, feitiçaria, apostasia e blasfêmia, entre tantas outras. Caberia a Emília Viotti, na década de 1950, as análises mais acuradas do que teria sido uma consciente "política do degredo" Laura de Mello e Souza segundo a qual o avanço da colonização aumenta de forma gradual os "elementos socialmente desclassificados",68 expressos através do estereótipo do "vadio colonial"69 que sobretudo na região aurífera representa uma espécie de reserva de mão de obra ao mesmo tempo em que consolida certas "formas culturais portuguesas" ${ }^{, 70} \mathrm{em}$ terras americanas.

No Brasil contemporâneo, o exílio de homens da "ínfima plebe" deu-se em locais como Guarapuava, no atual Paraná, São João das Duas Barras, entre Mato Grosso e Pará, em pequenos vilarejos mineiros situados no entroncamento dos rios Muricy e de Todos os Santos e até na ilha de Fernando de Noronha. Guardadas as devidas proporções, o desterro pós Independência manteria o incentivo ao povoamento de zonas fronteiriças ou litigiosas. A diferença reside no fato dos imbróglios territoriais não mais envolverem inimigos externos, tendo que centrar forças na extinção de grupos que, como os indígenas, freavam o controle do poder central sobre os rincões do país. Por mais que se creia no degredo como mecanismo autoritário de rearranjo social, a "instrumentalização dos condenados",71 talvez deva ser lida como aproveitamento dos

65 Cf. PRADO, P. Retrato do Brasil. São Paulo: Ibasa, 1981, p. 25; RUY, A. História Política e Administrativa da Cidade de Salvador. Salvador: Tipografia Beneditina Ltda., 1949, vol. I, p. 12; Idem. História da Câmara Municipal da Cidade de Salvador. Salvador: Editora da Câmara Municipal da Cidade de Salvador, 1953, p. 69; TAPAJÓS, V. História do Brasil. São Paulo: Companhia Editora Nacional, 1953, p. 67; NASH, R. A Conquista do Brasil. São Paulo: Companhia Editora Nacional, 1950, p. 126; CALMON, P. História da Civilização Brasileira. Rio de Janeiro: s/e, 1932, pp. 38-39; LOBO, A. de S. S. C. História da sociedade em Portugal - no século XV. Lisboa: s/e, 1949, p. 49.

${ }^{66}$ PIERONI, G. Os excluídos do Reino. Op. cit., p. 12.

${ }^{67}$ COSTA, E. V. "Primeiros povoadores do Brasil: o problema dos degredados". Revista Textos de História. Op. cit., p. 79.

${ }^{68}$ MELLO e SOUZA, L. Desclassificados do ouro: a pobreza mineira no século XVIII. Rio de Janeiro: Edições Graal, 1982, p. 59.

${ }^{69}$ Idem. O diabo e a terra de Santa Cruz: feitiçaria e religiosidade popular no Brasil colonial. São Paulo: Companhia das Letras, 1986, p. 65.

${ }^{70}$ Idem. Inferno Atlântico: demonologia e colonização (séculos XVI-XVIII). São Paulo: Companhia das Letras, 1993, p. 101.

${ }^{71}$ PONTAROLO, F. Homens de ínfima plebe: os condenados ao degredo interno no Brasil do século XIX. Rio de Janeiro: Apicuri, 2011, p. 148. 
dispositivos jurídicos por parte de instituições do Antigo Regime português que se encontram na origem do império brasileiro.

Forma histórica por excelência do exílio durante a modernidade lusitana, na historiografia o degredo pode ser visto como um "sistema unificado"72 ou, mantendo o mesmo sentido, por meio do "viés unificador do utilitarismo"73. Na ótica do paradigma estadualista, o desterro previsto tanto pelas Ordenações do Reino quanto pelos regimentos inquisitoriais é uma "forma de colonização coerciva",74 que vincula os códigos punitivos com as necessidades mais imediatas do império ${ }^{75}$. Das origens às consequências, a expatriação reforça o expansionismo em nome da assepsia social, expulsando do reino grande parte dos indesejáveis e perturbadores da ordem pública. Em termos marxistas tem-se o alinhavar da superestrutura, a "ideologia colonizadora"76, a uma infraestrutura que em vista da exígua população metropolitana e dos escassos recursos materiais adotaria práticas cada vez mais racionalizadas de exclusão ou, em outras palavras, de disciplinamento das forças produtivas com vista a garantir os domínios ultramarinos e assegurar os maiores rendimentos possíveis.

No sentido oposto, para Antonio Manuel Hespanha, a ordem social do Antigo Regime teria sido garantida por elementos muito menos dependentes do Estado, repousando em "ordens políticas infra estaduais"77 como a família e o ambiente doméstico, a Igreja e os demais espaços eclesiásticos e ainda as próprias tradições comunitárias. Em meio a tantos e às vezes sobrepostos "poderes periféricos", disposições legais perecem defender determinado conjunto de valores considerados indispensáveis para o convívio harmônico em detrimento do caráter estritamente punitivo, fazendo do direito penal um mecanismo simbólico antes de disciplinar. Ameaçando sem cumprir é que se buscou corroborar a obediência dos súditos a um monarca tido por senhor da justiça e distribuidor da graça divina na terra.

\footnotetext{
${ }^{72}$ TOMA, M. "Exclusão social, Estado e religião no Império Português". Revista Textos de História. Op. cit., p. 245.

${ }_{73}^{73}$ Idem, "A pena do degredo e a construção do império colonial". s/l, s/d, p. 442.

${ }^{74}$ COATES, T. Degredados e órfãs: colonização dirigida pela Coroa no império português (1550-1755). Trad. Lisboa: CNCDP, 1998, p. 28; Cf. Idem. "O sistema reage à mudança". Revista Textos de História. Op. cit., p. 233.

${ }^{75}$ Cf. FERREIRA, E. S. Origens e formas da emigração. Lisboa: Iniciativas Editoriais, 1976, pp. 31-33; PIERONI, G. Os excluídos do Reino. Op. cit., p. 88.

${ }^{76}$ MELLO e SOUZA, L. O diabo e a terra de Santa Cruz. Op. cit., p. 372.

${ }^{77}$ HESPANHA, A. M. "Conflito e resistência na sociedade do Antigo Regime". In.: Idem. Caleidoscópio do Antigo Regime. São Paulo: Alameda, 2012, p. 61.

${ }^{78}$ Idem. "O direito penal na Monarquia Corporativa". In.: Idem, p. 134.
} 
Talvez pese a favor desta tese o amplo recurso aos perdões régios para os casos de transgressão civil ou religiosa. Levando-se em conta a escassez de pessoas e recursos em relação às demandas do império colonial, isso talvez possa ser interpretado como reconhecimento da utilidade política e econômica do degredo. A assimetria do direito moderno dispensaria a adoção de uma única prática punitiva, impedindo qualquer homogeneidade sentencial, visto que um mesmo crime poderia ser punido de diferentes formas dependendo de quem, quando, como e onde fosse julgado ${ }^{79}$. Exemplo deste expediente "extremamente maleável" determinadas sentenças de desterro por crime não escandaloso, segundo o jargão da época, desde que o réu aderisse imediatamente às tropas portuguesas instaladas no interior de Angola em fins de quinhentos. Sob a égide da Inquisição, para citar um último, o auge da era do degredo por motivação religiosa adicionaria ao fenômeno a idéia de purgatório através do ritual da penitência seguida da purificação espiritual ${ }^{81}$.

\section{3. Especificidades portuguesas na Época Moderna}

Durante a Época Moderna, destacadamente no período da União das Coroas Ibéricas (1580-1640), pode-se ver o que o historiador francês Jean-Frédéric Schaub intitula de elementos "portadores de fermentos da discórdia" 82 também sob a ótica do exílio. Teriam sido três os movimentos que, cada um a seu modo, expressaram oposição explícita à adesão e, posteriormente, à continuidade da ligação de Portugal com a Monarquia Hispânica. No "inventário das turbulências", segundo o autor, figuram o sebastianismo, a corte itinerante de D. Antonio e, por fim, a Casa de Bragança. Vejamos em que medida e quais seriam exatamente os sentidos do exílio nessas forças políticas que, inegavelmente, contestavam a hegemonia dos Filipes sobre a porção mais ocidental da Península Ibérica - além do fato da monarquia dual ter sido alvo de metáforas que a retratavam enquanto exílio do próprio reino enquanto organização política.

\footnotetext{
${ }^{79}$ PIERONI, G. Vadios e ciganos, heréticos e bruxas. Op. cit., p. 44 e 53; Idem. Os excluídos do Reino. Op. cit., p. 87; Idem. Banidos. Op. cit., p. 23; COATES, T. "O sistema reage à mudança". Op. cit., p. 212. ${ }^{80}$ PIERONI, G. Banidos. Op. cit., p. 105.

${ }^{81}$ Cf. PIERONI, G. Os excluídos do Reino. Op. cit., p. 18, 91; Idem. Banidos. Op. cit., p. 9, 19, 23, 90; Idem. "Os excluídos do reino: A Inquisição portuguesa e o degredo para o Brasil-Colônia". Revista Textos de História, v.5, $\mathrm{n}^{\circ}$ 2, 1997, p. 27; Idem. "No purgatório mas o olhar no Paraíso: o degredo inquisitorial para o Brasil-Colônia”. Revista Textos de História, vol. 6, 1998; MELLO e SOUZA, L. O diabo e a terra de Santa Cruz. Op. cit., pp. 75, 79, 80, 375; Idem. Inferno Atlântico. Op. cit., pp. 89, 98.

${ }^{82}$ SCHAUB, J. F. Portugal na Monarquia Hispânica (1580-1640). Trad. Lisboa: Livros Horizonte, 2001, p. 55.
} 


\section{3. 1. D. Sebastião: exílio mítico do Desejado}

Nascido a 20 de janeiro de 1554, D. Sebastião ganharia o epíteto de Desejado em virtude de representar a única opção sucessória de manutenção de um rei "natural" na monarquia portuguesa, tendo em vista que seu pai e tios estavam todos mortos naquele momento. Logo em seguida ao parto, sua mãe, D. Joana, retorna à Espanha, deixando o menino aos cuidados dos sogros. Sua educação marcadamente religiosa ficaria a cargo da Ordem dos Jesuítas, na figura do padre Luís Gonçalves de Câmara, humanista português formado em Paris e na Itália que também desempenharia o papel de confessor do rei após 1566. Com apenas três anos de idade, ao varão seria dada a missão de suceder, D. João III, cognominado $O$ Piedoso ou $O$ Pio. Com a assunção do menino-rei, sua avó, D. Catarina de Áustria, passa a desempenhar a função de regente, permanecendo no posto até 1562. Durante esse período, a irmã de Carlos V e tia de Filipe II de Espanha foi vista como representante dos interesses castelhanos em Portugal, gerando desconfiança em grande parte da corte. Renunciaria ao posto logo após a vitória em Mazagão, sucesso que deu novo e último fôlego ao já cambaleante projeto imperial português no norte da África e que em certa medida acabou influenciando o destino do jovem monarca. No lugar dela, os Três Estado decidiram pelo Cardeal D. Henrique, que ficaria na regência por seis anos.

Começaria a governar de fato apenas em 1568, aos quatorze anos de idade e, segundo correspondências enviadas pelos embaixadores castelhanos, sofria com uma doença misteriosa que causava febres crônicas e cada vez mais fortes à medida que intensificava os exercícios de caça ao ar livre, podendo causar inclusive desmaios e "purgação" nas partes íntimas. Somada a outros fatores, à enfermidade sem diagnóstico se atribuiria a recusa de Filipe II em consentir o casamento de D. Sebastião com uma de suas filhas, a infanta Isabel Clara Eugênia. O matrimônio, aliás, parece não ter despertado muito o interesse do Desejado, que se mostrou aficionado por combater os mouros numa espécie de cruzada fora do tempo, segundo Fernando Braudel ${ }^{83}$. A partir de 1573, quando se intensificam boatos de que os inimigos islâmicos atacariam a costa sul do reino, o soberano em pessoa se incumbe de defender a região do Alentejo e Algarve. No ano seguinte, as expedições se voltariam para Ceuta e Tânger, terminando

\footnotetext{
83 BRAUDEL, F. O Mediterrâneo e o mundo mediterrânico na época de Filipe II. Trad. Lisboa: Dom Quixote, 1984, Vol. II, pp. 558-563.
} 
assim aquela que seria a primeira jornada africana de D. Sebastião. Daí por diante, a África ocuparia papel central na política expansionista que o Desejado visava implementar intuito de reverter o quadro de estagnação colonial herdado de seu avô e antecessor, D. João III. As intervenções em Moçambique e Congo, entre os anos de 1569 e 1571, parecem dar mostras nesse sentido.

A maior de todas as intervenções adviria do imbróglio sucessório ocorrido no Marrocos, no ano de 1576, quando da ascensão de Muley Malik ao reino de Fez. Apoiado pelos turcos, Malik voltava a ter o controle político após ter sido derrotado parcialmente por seu sobrinho, Moulay Mohammed ou Mulei Mahamet. Desprovido de forças político-militares, Mohammed procuraria ajuda nos reinos ibéricos, encontrando na receptividade de Portugal um esteio para reconquistar o poder que havia perdido pouco tempo atrás. No entender de D. Sebastião, o combate à ameaça islâmica não deveria tardar, motivo pelo qual, nesse mesmo ano, vai pessoalmente pedir suporte financeiro e militar ao tio, Filipe II, no evento que ficaria conhecido como entrevista de Guadalupe, pois realizada no famoso santuário localizado na Espanha. A termo do encontro, o monarca castelhano prometia o envio de 5 mil homens (mas só enviaria de fato 2 mil) que se somariam ao contingente de 14 a 20 mil combatentes de origem portuguesa, número que oscila de um relato para outro. Além disso, cedia 50 galés que uniriam forças a outras quinhentas, podendo chegar a mil, segundo alguns cronistas. De estrangeiros, além dos castelhanos, somaram-se cerca de 3 mil alemães e seiscentos italianos.

Prevista inicialmente para o meio de 1577 , devido a falhas logísticas a saída de Lisboa aconteceria apenas um ano depois. Em junho de 1578, portanto, D. Sebastião embarca na galé real com direção ao Marrocos. No trajeto, passou por Lagos, Cádiz, Tânger e Arzila para só então chegar a Alcácer Quibir. O momento decisivo se aproximava, e nem a informação de que as tropas inimigas somavam mais de 110 homens arrefeceu o ânimo do monarca que se via incumbido de derrotar a "seita de Mafoma". Liderando o exército cristão, na manhã de 4 de agosto o Desejado se embrenharia no combate corpo-a-corpo até desaparecer dos olhos de seus compatriotas, sucumbindo ao cerco das tropas de Malik. A derrota militar impingida aos portugueses fez grande número de mortos, sendo que uma pequena parcela de sobreviventes aos poucos começava a retornar a Portugal mediante pagamento de resgate junto aos vencedores da Batalha dos Três Reis, como ficaria conhecida na história marroquina. Ao esfacelamento do plano de conquista da África se seguiria a esperança de que o 
monarca não tivesse morrido, rumor que motivaria, a mando de Filipe II, a realização de uma cerimônia fúnebre, no mosteiro dos Jerônimos, em Lisboa, com os restos mortais atribuídos ao rei desaparecido. Mas isso não bastou.

O fracasso político-militar, já que o evento redundou na grave crise sucessória que origina a união das Coroas Ibéricas, serviu de mote para a produção de obras que, de um modo ou de outro, narraram os acontecimentos da jornada africana a partir do julgamento que cada autor fez do desfecho de Alcácer Quibir. Nesse sentido, a proliferação das biografias de D. Sebastião atesta a pluralidade de visões em torno de seus supostos méritos e defeitos. No que se refere aos letrados lusitanos, Manoel Pereira foi quem primeiro publicou em língua portuguesa, no ano de 1584. Dessa década, temse ainda a Crónica d'el rei D. Sebastião, de Bernardo da Cruz, e o depoimento de Miguel Leitão de Andrade na sua Miscellanea. Deixando de lado as crônicas anônimas, em fins do século XVI e começo do XVII figuram autores como Pedro de Mariz (Dialogos de varia historia - 1594), José Teixeira (Adventure admirable [editada em Paris] - 1601), D. João de Castro (Discvrso da vida do sempre bem vindo e apparecido Rey Dom Sebastiam [editada em Paris] - 1602), Jerônimo de Mendonça (Jornada de África - 1607), e Padre Amador Rebello (Relação da Vida d'el Rey D. Sebastião 1613). Já no XVIII, contam-se as de D. Manuel de Menezes (Chronica do Muito Alto e Muito Esclarecido Príncipe D. Sebastião Decimo Sexto Rey de Portugal - 1730), Frei Manuel dos Santos (História Sebástica - 1735), Padre José Pereira Bayão (Portugal Cuidadoso e lastimado com a Vida e Perda do Senhor Rei D. Sebastião - 1737), e, por fim, Diogo Barbosa Machado (Memorias para a História de Portugal Que Comprehendem o Governo del-Rey D. Sebastião - 1736/1751).

Mas foi fora de Portugal, mais precisamente na França, segundo a historiadora Jacqueline Hermann, que no mesmo ano de 1578 veio à tona a primeira versão sobre o acontecido. Trata-se da obra intitulada Les Voyages et Conquêtes des roys de Portugal et Indes d'Orient, Éthiopie, provavelmente da autoria do livreiro e impressor Jean d'Ongoys. Em seguida da versão francesa, deu-se a conhecer a de língua espanhola, chamada Relación de las Guerras de Berberia, da lavra do dominicano castelhano frei Luís de Nieto. Também em espanhol, embora sem datação precisa, encontra-se o relato do castelhano Luís de Oxeda no Comentario que trata de la infelice jornada q'el Rey D. Sebastião hizo em la Berberia el año de 1578. Na Europa central, por exemplo, a carta remetida pelos banqueiros Fuggers teria originado a impressão de 4.000 volumes da Portugalesische Schlacht na República Tcheca. Em 1585, se conheceria a mais célebre 
das obras estrangeiras dedicadas ao assunto, escrita por Ieronimo de Franchi Conestaggio, que a ela deu o nome de Dell'unione del regno di Portogallo ala corona di Castiglia. Editada primeiramente em Gênova, viria ser publicada em francês, inglês, latim e castelhano até 1610. É curioso notar que as primeiras repercussões escritas tenham surgido fora dos limites do reino português, fazendo crer que essa extraterritorialidade pode obedecer a lógicas internas a grupos de exilados que se instalaram em diversas cidades da Europa, sobretudo a partir da resolução das Cortes de Tomar. Os critérios que orientaram as referidas edições e o mapeamento dos personagens incumbidos tanto de escrever quanto de publicá-las ainda permanecem incompletos e carentes de maiores explicações.

Para os relatos estrangeiros, Hermann diz que, em sua maioria, teriam sido produzidos com a intenção de legitimar a anexação de Portugal aos domínios espanhóis, haja vista a ênfase na suposta irresponsabilidade do monarca por ter se exposto fisicamente ao campo de batalha. Seja como for, antes de tudo deve-se atentar para o fato da imagem ou representação do soberano estar diretamente atrelada ao contexto de produção de cada uma das referidas obras, levando em conta a naturalidade de seus autores bem como onde estavam quando do ato da escrita e, em determinadas circunstâncias, da publicação. Nessa perspectiva, a observação mais detida do historiador contemporâneo pode detectar algumas exceções. Uma delas, para efeito ilustrativo, é a obra escrita pelo fidalgo português D. João de Castro, onde se narra de forma elogiosa o refúgio e paradeiro do Desejado após a derrota em Alcácer Quibir. Escrita sob o impacto do homem calabrês que, em fins do século XVI, dizia ser D. Sebastião, nela vê-se claramente a agregação de elementos míticos à figura do monarca tido até então por derrotado.

Merece destaque a observação de que o exílio compreende uma etapa extremamente importante para a revelação profética de todo e qualquer messias, segundo o esquema proposto por Paul Alphandéry ${ }^{84}$. O estágio do "retiro", para ser fiel ao termo utilizado, seria precedido pela "eleição divina" e "provação", sendo sucedido pelo da "volta gloriosa". Isso posto, a especificidade do messianismo sebástico, levando-se em conta o referido Discvrso da vida do sempre bem vindo e apparecido Rey Dom Sebastiam, é embasar um messianismo que, mais do que enxergar o nascimento do monarca como desígnio divino e propor a derrota em terras africanas e a ascensão de

\footnotetext{
${ }^{84}$ Cf. ALPHANDÉRY, P. "Notes sur le messianisme medieval latin". Rapports Annuels de la Section des Sciences Religieuses. Paris: École Pratique des Hautes Études, 1898-1914.
} 
Filipe II como cativeiro português, encerra as especificidades duma experiência eremítica tão pura e penitente quanto a de Jesus Cristo, pelo menos em termos retóricos e analógicos. Segundo o letrado, após a derrota de 1578 o jovem rei teria se dirigido a Portugal, especificamente para o Algarve, onde teria visto de perto a "afronta do desbarato" que seu povo sentia naquele momento. Entristecido e arrependido, conta-se que participou de "muitas guerras" em defesa da fé católica, percorrendo para isso toda a Europa e partes da Ásia e África, estando acompanhado pelo lendário Preste João.

De todo modo, em 1602, quando a obra foi impressa na França, D. João de Castro supunha estar vivendo este terceiro estágio, o do retiro, temporalidade que só teria fim quando o Desejado retornasse do desterro para livrar Portugal do julgo castelhano. Pode-se dizer que o fato de voltar de algum lugar distante faz parte de um processo mais amplo de "maturação mitológica". Em termos simbólicos, a lenda de que o Desejado viria montado num cavalo, ou andando sobre o mar, ou saído de uma ilha (comumente chamada de nebulosa ou misteriosa), ou até de que teria se autopenitenciado na Terra Santa, só faz confirmar a ideia de que se encontrava longe de Portugal, vivendo um exílio mítico capaz de purgar os erros cometidos tanto na fatídica batalha quanto na escolha do herdeiro da Coroa. Em outras palavras, as figuras do "Encuberto" ${ }^{\circ 5}$, mito elaborado por Isidoro de Sevilha, e do "Rei Oculto", para tomar de empréstimo a expressão empregada pelo historiador Yvès Marie Bercé, estariam intrinsecamente ligadas a uma personagem que, rompendo a distância da pátria, em breve retornaria para redimir seus súditos ou talvez uma religião inteira.

\footnotetext{
${ }^{85} \mathrm{O}$ mito original, na verdade, previa um rei que "há de vir", seja num futuro próximo ou distante. O redentor, neste caso, ainda estava para nascer. O sebastianismo, ao contrário, inverte esta lógica, adaptando o mito a um monarca que já havia nascido e morrido, ou melhor, desaparecido. Isso só faz reforçar a idéia de que a ausência de D. Sebastião opera na lógica de um exílio mítico, secreto e silencioso, de fundamental importância para o processo de divinização do soberano.
} 


\section{3. 2. D. Antonio: exílio real do Indesejado ${ }^{86}$}

Ele, filho do Infante D. Luís! Ele, neto de D. Manuel! Ele, descendente de Reis que fizeram Portugal, corrido, expulso, caluniado, desnacionalizado.

Trecho da carta enviada por D. Antonio ao Papa Gregório XIII

Peça chave no cenário político de sua época, qualquer análise responsável sobre o período da União Ibérica deve levar em consideração a trajetória de D. Antônio (1531-1595), personagem que, durante a crise sucessória decorrente do desaparecimento de D. Sebastião na África, ousou contrapor-se ao também candidato e todo poderoso Filipe II. Assim como o monarca espanhol, julgou-se capaz de reivindicar a coroa portuguesa em nome da continuidade de um rei natural, despendendo esforços de todas as ordens para legitimar-se enquanto candidato da Casa de Avis. Sua audácia chega ao ápice quando decide se autocoroar rei de Portugal, despertando a fúria do duque de Alba que, a serviço do partido espanhol, lança uma verdadeira caçada ao Prior do Crato, como também ficaria conhecido após herdar o título, em 1555, em virtude do falecimento de seu pai. Acossado dentro do reino, decide pelo refúgio em cortes europeias adversárias dos espanhóis, vindo a falecer em Paris no ano de 1595. Sob tal ângulo, segue-se aqui a trilha sugerida por Mario Domingues, que fala brevemente dos efeitos duma "psicose do exílio" 87 , e, mais recentemente, de Jacquelinne Hermann ${ }^{88}$, que propõe o tema como eixo interpretativo capaz de jogar luz sobre a biografia de um exilado clássico, ou seja, aquele que se vê distante do genésico solo em decorrência de perseguição política.

No cenário pós Alcácer Quibir, a ascensão de D. Henrique ao trono parecia uma solução paliativa e efêmera. O Desejado não deixara filhos e o novo rei, tio-avô de D. Sebastião, já contava idade avançada para os padrões da época, além do que o seu posto de Cardeal o impedia de conceber descendentes. Sem um varão legítimo que pudesse herdar a Coroa, a crise estava instalada. Instável do ponto de vista político, esse curto reinado de (1578-1580) ficaria marcado, por um lado, pelas pressões exercidas por Felipe II para que tivesse seus direitos assistidos na questão sucessória, e, por outro,

\footnotetext{
${ }^{86}$ Inspirada na vida de D. Antônio, $O$ indesejado é uma peça de teatro, da década de 1940, escrita pelo intelectual e dramaturgo português Jorge de Sena (1919-1978). Em recente artigo, a historiadora brasileira Jacquelinne Hermann utiliza-se do epíteto para analisar a trajetória política do bastardo que pretendia ser rei. Cf. HERMANN, J. "Um rei indesejado: notas sobre a trajetória política de D. Antônio, Prior do Crato". São Paulo: Revista Brasileira de História, vol. 30, n 59, 2010, pp. 141-166.

${ }^{87}$ DOMINGUES, M. O Prior do Crato contra Filipe II. Lisboa: Livraria Romano Torres, 1965, p. 374.

${ }^{88}$ HERMANN, J. Op. cit, p. 154.
} 
pela inesperada pretensão de D. Antônio, até então conhecido como filho bastardo do Infante D. Luís. A insistência com que o Prior do Crato advogava seus direitos fez com que o Cardeal-Rei o declarasse "desnatural de mis Reynos", anulando as honrarias, títulos, direitos e privilégios e, por fim, desterrando-o de Lisboa temporariamente, pelo menos até que se encontrasse uma solução definitiva para a cada vez mais acirrada disputa pelo trono português.

Para melhor entender sua trajetória, faz-se necessário recuar até 1531, ano de seu nascimento. Filho bastardo ${ }^{89}$ de D. Luís de Avis com Violante Gomes, na infância iniciou os estudos no Mosteiro da Costa da Ordem de São Jerônimo, em Guimarães, passando por Évora, onde frequentou o curso de Teologia, até obter o diploma de Mestre em Artes junto ao Real Mosteiro de Santa Cruz de Coimbra. Formado, decide retornar a Lisboa e, no começo da década de 1560, ainda durante a minoridade de D. Sebastião, passa a frequentar com assiduidade os ambientes cortesãos, o que teria começado a gerar a gerar certo incomodo. D. Henrique, por exemplo, acusava-o de descontrole financeiro, além de desaprovar sua resistência à vida religiosa bem como uma vida privada supostamente desregrada do ponto vista dos preceitos católicos. Escancarando publicamente seu descontentamento, o Cardeal-Rei recusaria o filho de D. Luís para o arcebispado de Évora, excluindo-o também da lista que enumerava possíveis integrantes do Conselho de Estado.

A situação mudaria de figura durante o reinado seguinte, quando o Desejado empreenderia uma renovação das lideranças políticas, fazendo do primo um de seus homens de confiança. A partir de então, D. Antonio desempenha papel de relevância no projeto expansionista que voltava atenção para o norte da África. Prova disso é a nomeação do Prior, em 1574, para o posto de governador do Tânger, lugar que havia conhecido três anos antes. Mas a experiência duraria míseros três meses, tendo retornado a Portugal na companhia de D. Sebastião quando da volta de sua primeira jornada africana. Parece não haver muitas informações biográficas para o período que compreende a destituição do cargo e a partida para Alcácer Quibir, batalha na qual cairia refém dos mouros. Libertado graças aos préstimos do cavaleiro Gaspar da Grã e do judeu Abraão Gibre, retornar a Portugal para encontrar um cenário político em verdadeira ebulição.

\footnotetext{
${ }^{89}$ Tendo em vista a bastardia do primeiro rei da dinastia de Avis, D. João, filho ilegítimo de D. Pedro I com uma mulher galega, a propalada impureza de sangue do Prior do Crato operaria como artifício político utilizado, no contexto específico do pós Alcácer Quibir, para desautorizar as expectativas de D. Antonio ascender ao trono.
} 
A despeito da preferência pela duquesa de Bragança, D. Henrique falecera sem ter escolhido oficialmente um sucessor. Assume então uma Junta de Governadores enquanto não se decidia o nome no novo rei. Filipe II, o favorito, já vinha negociando a renúncia dos candidatos de maior relevância ${ }^{90}$, e muito provavelmente interpretara a resistência e as exigências de $\mathrm{D}$. Antonio como uma bravata sem grandes desdobramentos, mesmo que endossadas pelo Sumo Pontífice. Para todo efeito, o poderoso monarca ordena uma varredura nos arquivos portugueses no intuito de demonstrar por via documental a inaptidão de seu primo, chegando a apelar para o suposto conteúdo do testamento de D. Luís. De nada adiantaria. O conflito armado era cada vez mais iminente, vindo a estourar quando o Prior do Crato se proclama rei de Portugal, a 19 de junho de 1580, em Santarém. Tendo encontrado considerável respaldo da população local, chega a jurar as leis do reino e tomar o castelo da cidade. Antes, porém, da batalha decisiva, adentra Lisboa, sendo mais uma vez aclamado rei, desta vez pela câmara. Logo a seguir, Setúbal se renderia ao efêmero monarca, que também teria conseguido apoio de cidades como Coimbra e Porto.

O mais importante de todos os embates deu-se em fins de agosto, em Alcântara, decretando a definitiva vitória dos castelhanos sobre um precário e improvisado exército de resistência. A acachapante derrota do último Avis, que teria se ferido seriamente na batalha, inaugura um mergulho profundo no exílio, tanto no norte do país, num primeiro momento, quanto na Inglaterra e na França, numa fase posterior. Antes de partir para o estrangeiro, vale lembrar que, em 1581, estabelece uma corte improvisada nos Açores, sendo definitivamente expulso no arquipélago dois anos depois. O derradeiro espasmo de resistência viria em 1589, quando organiza um ataque surpresa a Portugal, chegando às imediações da capital, com o auxílio da armada inglesa de Francis Drake. De maneira geral, o sentido que permeia sua trajetória pode ser resumido pela missiva que o próprio D. Antonio envia ao Sumo Pontífice no atribulado ano de 1580. Nela se dizia "desnaturalizado" e "desnacionalizado" pelo então monarca D. Henrique, indícios de que talvez já previsse os dissabores do longo e intenso exílio que o aguardava. Nem o apoio encontrado em outros países, em figuras como a rainha inglesa Isabel I e Catarina de Médicis (mãe de Henrique III, rei da França), nem mesmo o breve do Papa contra a medida do Cardeal-Rei surtiriam o efeito desejado, isto é, a (re)conquista do reino. O desterro de quase quinze anos teve fim apenas com a visita da morte.

\footnotetext{
90 Ao todo, foram seis os candidatos ao trono português após Alcácer Quibir, a saber: Filipe II, D. Catarina, D. Antônio, Rainúncio Farnese, Catarina de Médicis e o duque de Saboia, Manuel Felisberto.
} 


\section{3. 3. Casa de Bragança: exílio de Vila Viçosa}

Desde a derrota de D. Catarina frente ao poderio espanhol, que resultou na ascensão de Filipe II ao trono português, a Casa de Bragança encontra na distancia da corte uma forma de resistir silenciosamente ao regime que começava a vigorar. Abrindo mão de participar da governação do reino durante o período em que o reino português esteve integrado à Monarquia Hispânica, foi o palácio de Vila Viçosa, no Alentejo, que os duques de Bragança escolheram para vivenciar uma espécie de exílio interno, visto que não tiveram necessidade de sair do reino e nem foram coagidos a tanto por parte das novas autoridades constituídas. O mote da "Corte na Aldeia"91, título da obra que Francisco Rodrigues Lobo dedica a D. Duarte, irmão de D. Teodósio e bisneto de D. João III, vincularia o refugio alentejano à busca por preservar os hábitos e costumes cortesãos. Reduto da resistência nacional para uns, símbolo da inatividade política para outros, o certo é que o duque de Bragança chegou a ter direito de ordenar fidalgos, garantindo condecorações, bem como moradias, pensões e foros. Também esteve sob seu poder a concessão de 40 comendas da Ordem de Cristo, 18 alcaidarias de castelos, patentes militares e até direito de padroado.

A essa família refugiada se atribuiria, de acordo com o historiador brasileiro Eduardo D’Oliveira França, o surgimento de um tipo ideal de homem barroco, especialmente em Portugal. O fidalgo da época da Restauração é "um herói frustrado, um herói artificial, um herói melancólico" $" 92$. Interiorizando a rebeldia ou se entregando à simples renúncia estóica, cada uma desses modelos exprimiam aspectos culturais basilares para o entendimento da sociedade portuguesa durante a monarquia dual. $\mathrm{O}$ primeiro, "frustrado", debatia-se com o tédio de uma vida medíocre que teimava em não oferecer possibilidades para demonstrar a honra das grandes casas nobres. O segundo, "artificial", buscava disciplinar as paixões humanas por meio do regramento da vida cotidiana, isto é, das relações entre homens e mulheres, pais e filhos e patrões e criados, dentre outras. O último, "melancólico", se condoía com a saudade e o sentimento nostálgico em relação à fecunda vida cortesã de antes da incorporação de Portugal aos domínios espanhóis.

\footnotetext{
${ }^{91}$ Cf. LOBO. F. R. Corte na Aldeia. Introdução, Notas e Fixação do texto de José Adriano de Carvalho. Lisboa: Editorial Presença, 1991.

${ }^{92}$ FRANÇA, E. D. Portugal na Época da Restauração. São Paulo: HUCITEC, 1997, p. 190.
} 
A discrição e afastamento são características que, segundo o historiador francês Jean-Frédéric Schaub, impedem a dita casa nobre oferecer uma alternativa real de oposição tanto quanto o sebastianismo e o antonismo teriam conseguido representar. Neste enquadramento, a alegada rivalidade dos duques com o monarca castelhano e a suposta resistência encabeçada por Vila Viçosa, ideias recrudescidas a partir do levante de 1640, operariam na lógica de uma "invenção retrospectiva dos escribas da Restauração"93. Da parte dos Bragança, a análise da correspondência mantida com Lisboa e Madri, ainda segundo Schaub, compromete a visão que se tinha até pouco tempo atrás de uma Casa nobre distante da realidade ou uma dissidência apática do ponto de vista político. Parte desse revisionismo histórico toma por base, por exemplo, o depoimento do conde de Salinas, vice-rei na época de Filipe III, que garantia o apadrinhamento do duque a pelo menos quatro integrantes do Conselho de Portugal, instância composta de sete membros.

Além da influência junto aos círculos cortesãos de Castela, intensificada por meio de matrimônios, fala-se também na possibilidade de, em duas ocasiões, a Casa ter ambicionado fazer um dos seus ocupar o posto de vice-rei. Em diferentes circunstâncias, D. Teodósio e D. Duarte teriam sido os escolhidos para isso, muito embora as expectativas não tenham se mostrado factíveis. O ponto alto, contudo, residiria no fato de D. João, o que viria a se tornar o quarto no nome, ter ficado na iminência de reavivar a política fiscal e militar que o Duque de Olivares planejava implementar em Portugal no intuito de reavivar a união dinástica firmada entre os dois reinos ibéricos desde o pacto de Tomar. Baseado nisso, Schaub diz ser excessivo, teleológico até certo ponto, ver nos Bragança uma força inteiramente dissidente. Melhor seria pensa-los a partir da dubiedade que, tudo leva a crer, teria pautado o comportamento dessa parte da elite portuguesa durante os sessenta anos de dominação estrangeira.

\footnotetext{
${ }^{93}$ SCHAUB, J. F. Op. cit., p. 63.
} 


\section{3. 4. União das Coroas Ibéricas: exílio de Portugal?}

Desde finais da Idade Média, a itinerância régia foi muito comum em Portugal. A corte deslocava-se dentro do reino em função de fatores diversos, tais como esforços de guerra, cerimônias religiosas, reunião de cortes, ameaças de doenças contagiosas e melhor adaptação às estações da natureza, para citar alguns exemplos. Mas com o passar do tempo, a realeza passa a privilegiar as regiões centrais do reino, tendência que corre em paralelo com a paulatina adaptação dos departamentos cortesãos aos espaços urbanos. Aos poucos, a corte "em andada" se transforma na corte "em estada" "94 Fixo, o rei se protagoniza no cenário político e acaba por atrair toda uma rede de apoio assentada basicamente na concessão de mercês e benesses. Em poucas palavras, estar perto e, dependo da situação, prestar serviços à pessoa régia significava maiores possibilidades de ascensão social ou de manutenção do status quo. Definitivamente instalados em Lisboa, durante a modernidade o monarca e o séquito que o servia não se viram na necessidade de sair da capital do reino, gerando ou corroborando a mística em torno duma cidade concebida ocupar papel de destaque no cenário político de consolidação das instituições monárquicas.

O protagonismo lisboeta seria em parte abalado com a ascensão de Filipe II. Excetuando os quase três anos em que, logo após o juramento em Tomar, o soberano lá residiu, com sua partida, em 1583, a cidade viu-se numa situação no mínimo inusitada. A Princesa Lisboa, como então era chamada, estava privada de abrigar o governante máximo, mas nem por isso deixaria de alimentar o sonho de um dia voltar a fazê-lo. Muitos dos discursos produzidos à época pintavam-na como cidade "adormecida", "sozinha" ou "quase viúva" 95 . Em termos retóricos, o alento a essa constatação viria da concepção providencialista, milenarista até, segundo a qual nela se fundaria a Nova Jerusalém que efetivaria a traslatio imperii subjacente ao Quinto Império proposto pela exegese do livro bíblico de Daniel. A nostalgia de ter abrigado a corte, portanto, pautou muitas das expectativas alimentadas durante os sessenta anos de união das Coroas, só sendo definitivamente superada com a aclamação de D. João IV e a consecutiva restituição do ambiente cortesão então a serviço da Casa de Bragança.

\footnotetext{
${ }_{94}$ Cf. GOMES, R. C. A corte dos reis de Portugal no final da Idade Média. Viseu: DIFEL, 1995.

95 ÁlvareZ, F. B. Portugal no tempo dos Filipes: Política, Cultura, Representações (1580-1668). Lisboa: Edições Cosmos, 2000, p. 168.
} 
A ausência do monarca, portanto, foi uma das principais características do Portugal filipino. O "rei ausente", segundo Ana Paula Megiani, teria que se fazer presente de alguma forma, o que envolvia uma série de representações de sua figura, na tentativa de superar a distância física e estabelecer ligações simbólicas da régia pessoa com os súditos lusitanos. Por um lado, a busca por legitimação conduziria os monarcas castelhanos a Portugal em duas ocasiões, 1581 e 1619, havendo em função disso grandes comemorações e festejos públicos. Por outro, os portugueses gestariam a ideia de que Lisboa, tida por ubilicus mundi, se tornasse a capital da Monarquia Católica, não economizando esforços para mostrar as vantagens de se estabelecer a corte de um império universal no extremo ocidente da Europa. Sua pretensa superioridade foi aventada em verso e prosa por inúmeros letrados, sendo comum nessas apologias a utilização da metáfora que associava a cidade à esposa e o rei ao marido. $\mathrm{O}$ mais famoso deles é o arbitrista Luís Mendes de Vasconcelos, autor do célebre Do sítio de Lisboa: diálogos, obra publicada no começo dos seiscentos. 


\section{Capítulo 2 - Exílio por escrito: história e historiografia}

[...] a historiografia do período filipino se revela a mais pura, ousada e venerada invocação da pátria em exílio.

Joaquim Domingues, De Ourique ao Quinto Império.

\section{1. D. João de Castro e Tomé Pinheiro da Veiga: manifestações lusitanas durante a modernidade}

Muitos foram os letrados portugueses que, em fins dos quinhentos e início dos seiscentos, estiveram longe do solo pátrio ${ }^{96}$. Um deles atendia pelo nome de Thomé Pinheiro da Veiga (Coimbra, Portugal 1571? - ?, 1656?), magistrado e jurisconsulto que, ao longo da vida, coincidente com toda a extensão do regime filipino, desempenhou as funções de procurador da Coroa, desembargador do Paço e da Casa de Suplicação, vedor da Fazenda e chanceler-mor do Reino. Após a Restauração, é bom lembrar, o autodenominado "mentiroso" e "ocioso" acabou se identificando com a causa brigantina, apoiando a ascensão de D. João IV. Nascido em Coimbra, até hoje não se sabe o motivo pelo qual tomou a direção de Valadolide, na Espanha, quando contava aproximadamente 35 anos de idade, permanecendo na então capital da monarquia hispânica durante oito meses, de dezembro de 1604 a julho de 1605 . Sob o pseudônimo de "Turpín", ali teria escrito uma obra intitulada Fastigimia, também chamada de Fastigínia, termos que carregariam o sentido de "fatos geniais". Ao que tudo indica, o manuscrito original sofreu reparações nos anos de 1607 e 1620, quando o autor já havia retornado a Portugal $^{97}$. De todo modo, a imagem que Veiga faz de si pode ser

\footnotetext{
96 A seguir constam alguns dos autores e obras com as respectivas datas de publicação: Luís Pereira Brandão (Elegíada - 1588), Jerônimo Corte Real (Naufrágio de Sepúlveda - 1594), Francisco Rodrigues Lobo (Condestabre de Portugal - 1609), Vasco Mousinho Branco (Afonso Africano - 1611), Manuel Bocarro Francês (Anacephaleosis da Monarquia Lusitana - 1616/ Tratado dos Cometas - 1619), Francisco C. R. de Moura (Novíssimos do Homem - 1623), Manuel Tomás (Poema del Angelico Doctor Sancto Thomaz - 1625/ Insulana - 1635), Francisco de Sá Menezes (Malaca Conquistada - 1634), Gabriel Pereira de Castro (Ulisseia - 1636), Miguel da Silveira (El Macabeo - 1638), Antonio de Souza Macedo (Ulissipo - 1640), Duarte Nunes Leão (Origem da Língua Portuguesa - 1606), Manuel Severim de Faria (Vários Discursos Políticos - 1624), Antonio de Souza Macedo (Flores de Espanha Excelências de Portugal - 1631), Francisco Manuel de Melo (Epanáfora Política/Alterações de Évora - 1637), Antonio de Vasconcelos (Anacephaleosis - 1621), Manuel de Faria e Souza (Fuente de Aganipe e Rimas Várias 1624), Bernarda F. de Lacerda (España Libertada - 1618), Francisco Soares Toscano (Paralelos - 1623), Miguel Leitão de Andrada (Miscelânea - 1629), Serafim de Freitas (Do justo império asiático dos portugueses - 1625), Salgado de Araújo (Ley Regia de Portugal - 1626).

${ }^{97}$ Ao lado de Gabriel Pereira de Castro e Nuno da Fonseca, Thomé Pinheiro da Veiga completa a lista de jurisconsultos que, no começo da década de 1620, reprovaram a publicação de uma obra chamada $D o$ Justo Império Asiático dos Portugueses, de autoria do Frei Serafim de Freitas. Trata-se, curiosamente, de
} 
apreendida no "Protesto do Author", quando alerta para o provável "escândalo" do público frente a um "asno" que dizia tantos "despropósitos".

O livro de título inusitado divide-se em três partes. A primeira, Philipestrea, aborda as cerimônias da semana santa e a celebração do nascimento do príncipe herdeiro. Pratilogia, a segunda, trata da vida cotidiana na cidade após a partida da família real. Por fim, a Pincigraphia traz uma pormenorizada história natural e moral do espaço urbano de Valadolide. Embora haja grande divergência quanto à sua publicação em tipos móveis, fato sustentado por Inocêncio e negado por Barbosa Machado, apurouse até agora a existência de doze manuscritos espalhados pela Europa, a saber: nas bibliotecas municipais de Évora e do Porto ${ }^{98}$, na Nacional de Lisboa e de Paris, na da Universidade de Coimbra, nos fundos documentais da Real Academia de Língua Espanhola, em Madri, na Academia das Ciências da capital portuguesa, e, por fim, na British Library, em Londres. Há também os que se encontraram sob a posse dos portugueses José Pereira de Sampaio e Aníbal Fernandez Thomaz ${ }^{99}$.

Em termos literários, Veiga assume a importância de ter sido o primeiro escritor a fazer referência ao personagem cervantino D. Quixote ${ }^{100}$. Há quem diga que seu "vanguardismo" inicia, ou antecipa, o narrador "crítico" e "debochado" que só se consolidaria na contemporaneidade ${ }^{101}$. Outro afirma se tratar de um livro “jovial” e “desprendido", uma raridade para a época ${ }^{102}$. Mais pessimista é a visão que ressalta uma suposta "consciência da inferioridade nacional face a Espanha""103 e o paradoxo entre a

um português radicado na mesma Valadolide sobre a qual Veiga escrevera a Fastigimia duas décadas antes de endossar este parecer negativo. Nele, entre outras advertências, os referidos juristas recomendavam diretamente a Filipe IV "[...] que por nenhuma maneira convinha imprimir como resposta pública dada por ordem de Sua Majestade, pois que, quando importara fazê-lo, houvera de ser com mais autoridade e notícia das bulas e princípios em que se funda a justiça de $\mathrm{S}$. M. e por diferente termo do que no dito tratado se sugere." A despeito das opiniões contrárias, em 1625, a oficina de Jerónimo Morillo, tipógrafo da Universidade de Valadolide, enfim publicou, sob licença régia, a edição espanhola da obra, versão que teve circulação proibida a pedido do próprio Conselho de Portugal. Apud: CAETANO, M. "Introdução". In.: FREITAS, S. de. Do Justo Império Asiático dos Portugueses (De Iusto Imperio Lusitanorum Asiatico). Trad. Vol. I. Lisboa: Instituto Nacional de Investigação Científica, 1983, p. 43.

${ }^{98}$ Versão recentemente transcrita e editada pela Imprensa Nacional/Casa da Moeda.

${ }^{99}$ Cf. DÍAZ-TOLEDO, A. V. "Fastiginia de Tomé Pinheiro da Veiga. Edición de los días 10 y 28 de junio de 1605: primer documento de la recepción del Quijote". Anales Cervantinos, vol. XXXIX, 2007, pp. 312-313.

${ }^{100}$ Cf. ÉMIEUX, A. "La Fastigimia (1605) de Pinheiro da Veiga. Ou la vie et la littérature à Valladolid, capitale de l'Espagne". Persée: Bulletin Hispanique, anée 1958, vol. 60, no 2.; DÍAZ-TOLEDO, A. V. "Fastiginia de Tomé Pinheiro da Veiga. Edición de los días 10 y 28 de junio de 1605: primer documento de la recepción del Quijote". Anales Cervantinos, vol. XXXIX, 2007, pp. 309-343.

101 ANGELINI, P. R. K. "Fatos geniais: o lugar de Thomé Pinheiro da Veiga na tradição de narradores dramatizados na literatura portuguesa". s/e, s/d, pp. 526-535.

${ }^{102}$ SAMPAIO, J. P. de. "Apresentação". In.: VEIGA, T. P. da. Fastigimia. Lisboa: Imprensa NacionalCasa da Moeda, 1988, p. 4.

${ }^{103}$ REAL, M. Nova teoria do sebastianismo. Lisboa: Publicações Dom Quixote, 2013, p. 12. 
"grandeza de um país e a pequenez do outro"104, nítida referência à subalternização de Portugal durante a União das Coroas Ibéricas. De todas as chaves interpretativas, continua válida a que privilegia o estudo das sistemáticas analogias da prosa veiguista, perspectiva à qual se deve acrescentar, a nosso modo de ver, o exílio enquanto esteio das aproximações e distanciamentos que não necessariamente estabelecem "respectiva identidade nacional" ${ }^{\text {"105 }}$ para cada reino da Península Ibérica. Aliás, a historiografia portuguesa, representada por Maria Belchior, concebe a fonte como relato de viagem, enquanto a abordagem espanhola sustenta-a como "libro de estância"106, privilegiando o “destino" e não a "origem" do exílio/exilado. Em poucas palavras, está-se diante de análises historiográficas que colocam Thomé da Veiga "dentro" e "fora" ao mesmo tempo, atrelando temas das mais diversas ordens ao desterro que indubitavelmente se divide entre a vivência no estrangeiro e a distância do genésico solo.

A distância da pátria também atingiria D. João de Castro (Lisboa, Portugal 1550 ? - Paris, França 1628?), neto homônimo do vice-rei das Índias que viveu entre 1500 e 1548. Seu avô havia se casado D. Leonor Coutinho, e do matrimônio nasceram nove filhos, sendo um deles D. Álvaro (1525-1575), fiel escudeiro do patriarca na administração ultramarina. Retornado a Portugal após presenciar a morte do pai em Goa, este, por sua vez, envolveu-se com uma cristã nova, a qual deu à luz o futuro patrono do sebastianismo. Entre idas e vindas, em seguida ao nascimento do rebento, D. Álvaro passou por breve exílio em algumas cidades italianas, e, em Roma, chegou a travar relações com o antigo bispo de Viseu, D. Miguel da Silva ${ }^{107}$, expulso de Portugal a mando de D. João III. Reintegrado ao mundo cortesão lisboeta, casou-se com a prima, Ana de Ataíde (1543-1574), com quem teve onze filhos ${ }^{108}$, além dos quatro ilegítimos ${ }^{109}$. Nos anos seguintes, chegou a cumprir algumas missões internacionais de destaque, tendo sido enviado à França com o fito de prestar condolências a Francisco II,

\footnotetext{
${ }^{104}$ BELCHIOR, M. de L. "Prefácio". In.: VEIGA, T. P. da. Fastigimia. Op. cit., p. 12.

${ }^{105}$ Ibidem.

${ }^{106}$ DÍAZ, J. "Presentación”. In.: Fastiginia. Vida cotidiana en la corte de Valladolid. Valladolid: Ambito, 1989, p. 9.

${ }_{107}$ Cf., p. 18 , nota 30.

108 D. Álvaro e D. Antonio morreriam ainda na infância, e D. João e D. Luís, em Alcácer Quibir, em 1578. Também enviado para a batalha, D. Manoel conseguiu se safar, retornando a Portugal. Os outros homens conheceram destino melhor. D. Francisco ocupou o cargo de Inquisidor Geral e reitor da Universidade de Coimbra. D. Miguel foi Inquisidor Geral da Índia e D. Fernando participou do conselho filipino. Sobre as mulheres, conta-se que D. Ana e D. Catarina tornaram-se abadessas no mosteiro de Castanheira, embora não se tenha maiores informações sobre a vida de D. Violante.

${ }^{109}$ Não se pode dizer se todos eram filhos da mesma mãe, mas, além de D. João de Castro e D. Gregório, morto ainda criança, sabe-se que D. Fernando tornou-se frei da ordem dos dominicanos e D. Garcia, "religioso do carmo".
} 
em virtude do falecimento de seu pai, e, ao mesmo tempo, negociar o casamento do então monarca lusitano, D. Sebastião, com Margarida de Valoirs.

Em diferentes circunstâncias, D. João de Castro externou o orgulho que sentia do tronco paterno, esforçando-se por mostrar as relações que seu pai tivera com D. Sebastião, intensas a ponto de D. Álvaro ter sido nomeado, além de embaixador, vedor da fazenda e membro do Conselho de Estado, órgão diretamente subordinado ao soberano. A prova de fidelidade para com o monarca se estendia a toda família, já que três de seus irmãos haviam lutado em Alcácer Quibir, dois dos quais mortos em campo de batalha e apenas um salvo. Mesmo bastardo, a proximidade com a família Castro vinha dos tempos de infância, quando teve a oportunidade de desfrutar da companhia da avó, D. Leonor, principal responsável por seu ingresso, no começo da adolescência, no mosteiro de Penhalonga, nas imediações de Sintra, onde permaneceu por cerca de quatro anos. A mudança de ares veio no verão de 1567 , quando se matriculou no colégio de Évora, conhecido pela rigorosa defesa dos princípios contra reformistas. Permaneceu na instituição evorina por aproximadamente dez anos, tomando contato com textos filosóficos e teológicos e amadurecendo ideias que muito provavelmente ajudaram a fundamentar seus futuros escritos.

Durante o período de estudos, que envolveram os cursos de Artes e Teologia, seu pai veio a falecer, intercorrência que o fez retornar a Lisboa, segundo seu relato, no fatídico mês de agosto de 1578, quando começavam a circular no reino as primeiras notícias que davam conta da derrota portuguesa no norte da África. Permaneceu na capital por um ano, dirigindo-se, logo a seguir, a uma abadia localizada no Minho, onde se recolheria por mais outro, para fazer valer a mercê que previa um ordenado fixo de significativa importância. É neste período, coincidente com a vacância do trono português, que Castro decidiu apoiar D. Antonio, único candidato que ousou desafiar o mais poderoso dos concorrentes, o monarca espanhol Filipe II. Reside aqui, exatamente, o ponto de inflexão de sua biografia, já que, em fins de 1581, rumou para a França no intuito de se colocar à disposição das forças antonistas, chegando inclusive a compor o Conselho de Estado do monarca itinerante. Em defesa da causa, participou das expedições às Ilhas de S. Miguel e Terceira, ocasião em que acabou ferido na perna em virtude de um tiro de arcabuz. Após tais fracassos, tomou a direção de Portugal pela última oportunidade, numa visita relâmpago que duraria menos de um mês. Dali dirigiuse aos Países Baixos, onde embarcou novamente para a França. 
Do território francês a corte exilada partiu para a Inglaterra, lugar em que, de acordo com o Tratado dos Portugueses de Veneza, Castro e seus conterrâneos sofreram “desamparo, grandes neçessidades, nudezas, fomes, e alguas mortes”. O sofrimento se transformou rapidamente em insatisfação, e a ruptura com D. Antonio parecia cada dia mais próxima. Ela se consumou com a fuga e o retorno do fidalgo à França, em 1587, mediante a utilização de passaporte falso. Não por acaso, a deserção do partido antonista desembocou no início da crença de que D. Sebastião não havia morrido em Alcácer Quibir, e até num inusitado flerte infrutífero com a defesa dos direitos sucessórios da Casa de Bragança. O fato é que sua primeira obra, escrita em apenas um dia, 25 de julho de 1588, ganhou o título de Discurso fallando com El Rey D. Sebastião. Nela deixou entrever a figura de D. Antonio como instrumento de punição divina aos portugueses. Contudo, para desacreditar os direitos e virtudes do pretendente, a renegação faz supor que o letrado tenha iniciado um processo de reescrita de sua história, sobretudo do período em que esteve a serviço do Prior do Crato. A este respeito, o historiador Joaquim Verissimo Serrão observou a seguinte contradição:

A dolorosa velhice e os sofrimentos por que tinha passado em quase meio século de penoso exílio haviam feito esquecer ao infeliz D. João de Castro que também ele achara legítima a aclamação de D. Antonio, para o que viera expressamente das províncias do norte a fim de seguir o partido fiel à causa nacional $^{110}$.

No exílio parisiense passou a viver "como hu pedacinho de taboa no naufragio", dificuldades que ocasionaram sua breve reintegração às fileiras antonistas então sediadas na Inglaterra, para onde voltou no ano de 1593. Inusitadamente, na ocasião disse ter assegurado a D. Antonio que seu primo ainda estava vivo. Fazendo parte da corte itinerante, retornou novamente a Paris, mas a morte do Prior do Crato veio antes do fim de 1595. Apesar do revés, Castro rapidamente encontrou nova causa pela qual lutar. Missivas enviadas por Antonio de Brito Pimentel e Pantaleão Pessoa atestavam o aparecimento, na cidade de Veneza, de um homem de "pouca conta" que alegava ser D. Sebastião. Agregando cada vez mais gente, o alvoroço começou a preocupar as autoridades locais, que imediatamente comunicaram os espanhóis sobre o fato. Tratavase, na verdade, de Marco Túlio Catizone ${ }^{111}$, homem de meia idade casado com Paula

\footnotetext{
${ }^{110}$ SERRÃO, J. V. O reinado de D. Antonio, Prior do Crato. Vol. I (1580-1582). Coimbra: s/e, p. 37.

${ }^{111} \mathrm{Na}$ versão apresentada por Castro, tanto no Discurso (1602) quanto na Ajunta (?), este era o nome do italiano que o D. Sebastião aparecido em Veneza enviara a Portugal como mensageiro da boa nova de que estava vivo e disposto a retomar o trono usurpado por Filipe II desde 1580.
} 
Gallardete, e filho, segundo declaração do próprio, de Hipólito e Bertonca Catizone. Oriundo de uma pobre família da Calábria, Túlio disse ter assumido o papel de rei de Portugal em virtude da insistência de três ou quatro portugueses amigos seus que haviam lutado em Alcácer Quibir.

A despeito dos esforços de Castro e outros lusitanos, que, em 1600, ainda em Veneza, haviam conseguido sua liberdade provisória, a repressão castelhana veio através do decreto que o exilou da cidade dos Doges. Valendo-se disso, o plano de fuga organizado pela comunidade lusa, composta por cerca de vinte pessoas ${ }^{112}$, consistia em embarcá-lo para a França via Livorno, mas a rota não se concretizou, e, na companhia do frei Crisóstomo, responsável por adotar caminho diferente do planejado, o impostor caiu preso novamente, desta vez em Florença. Conduzido a Nápoles, e detido por quase um ano, tomou conhecimento da sentença que o enviou às galés. O serviço forçado o levou para dentro do território espanhol, primeiramente a Sevilha e, numa segunda etapa, à fortaleza de San Lúcar de Barrameda. Vivia-se, naquele momento, um impasse de ordem jurídica. Os espanhóis não sabiam como colocar um ponto final no imbróglio, embora já tivessem descartado, temendo uma possível sublevação popular, a ideia de julgá-lo em território português. A opção pela pena de morte, executada em 1603, decorreu do rumor de que os franceses preparavam uma invasão a Portugal com o objetivo de (re)conduzir D. Sebastião ao trono que se supunha usurpado.

Em busca de apoio político, Castro dirigiu-se, pela última vez, ao genésico solo, entre abril e julho 1601, passando pelas cidades de Lisboa, Viseu e Aveiro. Entusiasmado, pôs-se a escrever, no ano seguinte, a "biografia mitificada" que ganhou o nome de Discvrso da vida do sempre bem vindo e apparecido Rey D. Sebastiam, sua primeira obra impressa ${ }^{113}$. O mote sebastianista ainda sustentou a feitura da Paraphrase

\footnotetext{
112 Para maiores informações, ver, nas considerações finais, o item "Sebastianismo além-fronteiras: exílios conectados?".

${ }^{113}$ Em função das críticas a D. Antonio, o Discurso seria rebatido, em 1603, pela anônima Resposta que os tres estados do Reyno, a. s., Nobreza, Clerezia e Povo, mandarão a Dom João de Castro, sobre um discurso que lhes dirigio, sobre a vinda e aparecimento del Rey Dom Sebastião. O letrado atribuiu sua autoria a Diogo Botelho, Ciprião de Figueiredo, D. Manuel e D. Cristóvão, filhos do Prior do Crato, e Frei Estevão de Sampaio. Sobre a imputação ao último personagem, o historiador João Carlos Serafim refutou-a em virtude do frei, naquele momento, estar preso na Espanha. De todo modo, a obra acusava o sebastianista de ingratidão, insinuando que só dispensava apoio a quem oferecesse mais dinheiro. Sobre a alegada ilegitimidade do monarca, mencionou-se a contradição oriunda do fato do fidalgo nunca a ela ter feito referência durante o tempo em que servira ao "partido da pátria". Aliás, sua fama adviria justamente da participação na corte itinerante, motivo que, por si só, tornaria sua saída da Inglaterra uma fuga injustificada. A isso se somou o perdão concedido quando de sua reintegração, em 1592, ocasião em que o efêmero soberano, segundo a Resposta, o "alimpou de toda a çugidade" e o "alevantou do monturo". Aventou-se também a bastardia do neto do vice-rei das Índias como fator depreciativo. Contudo, a se julgar procedente a afirmação de que os filhos de D. Antonio participaram da redação do livro, é no
} 
et concordancia de algvas Prophecias de Bandarra, çapateiro de Trancoso, de 1603, livro que, como o anterior, publicou na França. Malograda a conspiração de Veneza, os envolvidos no conluio se viram obrigados a fugir. O fidalgo teve a sorte de não ter sido preso, tendo encontrado guarida na casa do abastado Diogo Manuel, compatriota residente em Paris. O pai de Diogo, Manuel Lopes, havia se exilado, em fins dos quinhentos, em função do apoio a D. Antonio, e, desde então, o clã decidira pela permanência na capital francesa. Mesmo com a inesperada dificuldade financeira, que fez com mudassem para uma "câmara de alluguer", Castro permaneceu sob a proteção de seu mecenas até a morte, acontecida, ao que tudo indica, no ano de 1628.

Durante seus quase oitenta anos de vida, grande parte deles vividos fora da terra natal, legou à posteridade grande volume de escritos, tornando-se referência obrigatória para os debates em torno das manifestações messiânicas de tradição portuguesa, sobretudo durante a União das Coroas Ibéricas. A despeito da reconhecida importância, sua figura ainda permanece obscura. Isso se deve, entre outros fatores, ao desconhecimento de sua obra integral, que contabiliza vinte e dois volumes $\operatorname{manuscritos}^{114}$ e dois livros impressos ${ }^{115}$. Sabe-se apenas que, no século XVIII,

mínimo contraditória a veiculação deste elemento como motivo de desonra, visto se tratar de uma característica marcante na biografia do pai deles. A contenda, todavia, não terminou assim. Retrucando a Resposta, Castro redigiu, em 1604, o Tratado Apologético, embora só fosse reconhecer a autoria do manuscrito dezesseis anos depois, quando se meteu a escrever a Renovaçam do Tratado Apologético.

${ }^{114}$ A coleção só foi de fato organizada quando de seu depósito na Biblioteca Nacional de Lisboa (BNL), em 1859, sob o título de "Collecção Original das Obras de D. João de Castro, Filho Natural de D. Alvaro de Castro, Neto do Grande D. João de Castro, Quarto Vice-Rei da India. Escriptas em Paris nos annos de 1588-1628". Cf. Diccionario Bibliographico Portuguez. Lisboa: CNCDP, s/d, CD-ROM, vol. III, verbete “D. João de Castro", vol. IX, verbete "Gonçalo Anes Bandarra”. Segundo Diogo Barbosa Machado, estes volumes pertenceram ao seu irmão, D. José Barbosa, clérigo regular, cronista da Casa de Bragança e censor da Academia Real. Cf. Bibliotheca Lusitana. Lisboa: CNCDP, s/d, verbete "D. João de Castro". A Cátedra Jaime Cortesão, sediada no Departamento de História da Faculdade de Filosofia, Letras e Ciências Humanas (FFLCH) da Universidade de São Paulo (USP), digitalizou todos os 22 volumes, a saber, com os títulos originais: $1^{\circ}$ vol. De Quinta et ultima Monarchia Futura, rebusque admirandis nostri temporis, 1597-1606 (cód. 4371); $2^{\circ}$ vol. Advertimentos ao sempre bem vindo, e apparecido Rey D. Sebastião, 1604 (cód. 4372); 3-5º vols. Aurora, 1604-1605 (cód. 4373-75); $6^{\circ}$ vol. Tratado das Ordens, isto he: Ornamento, honra, e gloria de quatro Ordens, de que profetizou o Venerauel Abbade Joaquim: em testemunho dos illustres merecimentos dellas, e delle, 1614-1615 (cód. 4376); $7^{\circ}$ vol. Novas Flores sobre a Paraphrase do Bandarra, com algumas retrataçoens de seu Autor, 1607 (cód. 4377); $8^{\circ}$ vol. Segundas Expoziçoens mais amplas, e com outras Declaraçoens sobre o Apocalypse, 1612 (cód. 4378); $9^{\circ}$ vol. Declaraçoens a alguns Capitulos do Propheta Daniel, 1613 (cód. 4379); 10 vol. Paraphrase, e Concordancia das Prophecias e Trovas de Gonçallo Annes Bandarra, Çapateiro de Trancoso, 1614 (cód. 4380); $11^{\circ}-13^{\circ}$ vols. O Antichristo, ou Prophecias, e Revelaçoens sobre elle, 1615-1616 (cód. 4381-83); $14^{\circ}$ vol. Avizos Divinos, e Humanos pera os memorandos Conquistadores da Terra de Promissão dos nossos tempos, que he todo o Universo, 1617 (cód. 4384); 15 $5^{\mathrm{o}}$ vol. Tratado Apologetico contra hum Libello Diffamatorio que imprimirão em Francês certos Portugueses com o Titulo seguinte: 'Resposta, que Tres Estados do Reyno de Portugal, a saber, Nobreza, Clerezia, e Povo mandarão a D. João de Castro sobre hum livro, que lhes dirigio acerca da vinda, e apparecimento del Rey Dom Sebastião, 1620 (cód. 4385); $16^{\circ}$ vol. Paineis Divinos, onde se reprezentão alguas das grandes Merces que Deus tem prometidas ao seu Povo Occidental da Igreja Romana; com alguãs particularidades ja feitas por elle aos 
apareceu como pauta duma seção da Academia Real de História Portuguesa, tendo seus participantes, segundo Barbosa Machado, elogiado o conteúdo dos autógrafos, dizendo que mereciam "luz pública".

Com toda certeza, o estudo do sebastianismo caminhará pari passo com a transcrição e análise dos referidos manuscritos, rompendo o círculo vicioso que, até pouco tempo atrás, condicionava a historiografia aos dois livros publicados na França, ou, quando muito, ao primeiro volume da coleção depositada na Biblioteca Nacional de Lisboa, uma espécie de manifesto intitulado Da Quinta \& Ultima Monarchia Futura. Esta dissertação, inclusive, não se exime da crítica, já que, em parte, resulta do projeto de iniciação científica que buscou destrinchar os fundamentos teológico-políticos do célebre tratado $^{116}$. Tendo em vista o longo período de desprestígio acadêmico do tema, visto, muitas vezes, como pouco relevante para a compreensão do Antigo Regime, bem como as dificuldades dos historiadores brasileiros em encontrar e reunir documentação suficientemente densa para a formulação de hipóteses de trabalho, concebe-se a presente pesquisa como desdobramento da produção intelectual a seguir apresentada. No âmbito historiográfico, portanto, a explanação abordará as contribuições que ajudaram a sedimentar o legado de D. João de Castro.

Reys de Portugal, e aos Portugueses, 1621 (cód. 4386); $17^{\circ}-18^{\circ}$ vols. Tratado dos Portugueses de Veneza, ou Ternario, Senario, e Novenario dos Portugueses, que em Veneza solicitarão a liberdade del Rey D. Sebastião: com huã breue menção do Snr. D. Antonio, 1622-1623 (cód. 4387-88); 19º vol. (cód. 4389), composto de quatro obras: $1^{\circ}$. Juramento del Rey D. Affonso Henriques. Em Latim, e Português (s/d), 2º Discurso dirigido a El Rey D. Sebastião (1588), $3^{\circ}$. Remonstrança feita de novo aos Conselheiros d'Estado, e Privado del Rey Christianissimo, em suscitação da cauza, e acontecimentos del Rey D. Sebastião (1603), 4. Genealogia dos Reys de Portugal até El Rey D. Sebastião (1621); $20^{\circ}$ vol. Segundo Apparecimento del Rey D. Sebastião dezaseisto Rey de Portugal; com a repetição summaria do Primeiro, e de toda a sua vida: dirigido aos Tres Estados do Reyno de Portugal, a saber, ao da Clerezia, ao da Nobreza, e ao do Povo (cód. 4390); $21^{\circ}$ vol. (cód. 4391), composto de duas obras: $1^{\circ}$. Resumo das vidas dos Reis de Portugal des del Rey D. Affonso Henriques até D. Pedro I (s/d), $2^{\circ}$. Histoirie du Roy Don Sebastien; $22^{\circ}$ vol. Notandos Varios, s/d, (cód. 4392).

${ }^{115}$ Discvrso da vida do sempre bem vindo, e aparecido Rey Dom Sebastião nosso senhor o Encuberto des do se nascimeto tee o presente: feito, e dirigido por D. João de Castro aos tres Estados do Reyno de Portugal: comvem a saber ao da Nobreza, ao da Clerezia, e ao do povo (1602) e Paraphrase et concordancia de algvas Prophecias de Bandarra, çapateiro de Trancoso. Por Dom Ioam de Castro (1603). Segundo o sumário dos volumes depositados na Biblioteca Nacional de Lisboa (BNL), ambas foram publicadas em Paris, sob licença régia, por Martin Verac. Em Portugal, uma edição fac-similada do Discurso foi publicada em Lisboa, em 1994, pelas Edições Inapa. A Paraphrase também conheceu edição fac-similada, no Porto, em 1942, pelas Edições Lopes da Silva.

116 Orientada pelo Prof. Dr. Luis Filipe Silvério Lima no curso de História da Universidade Federal de São Paulo (UNIFESP), a pesquisa intitulada "A idéia de poder monárquico em D. João de Castro: transcrição e estudo do manuscrito Da Quinta \& Ultima Monarchia Futura (1597-1606)" foi financiada pelo PIBIC-CNPq, e teve duração de três anos, de 2007 a 2010. Em 2009, a pesquisa foi agraciada com o primeiro lugar na categoria Humanidades do XXIII Prêmio Pereira Barreto, distinção concedida pelo Departamento de Cultura Científica da UNIFESP. As reflexões acumuladas durante a vigência da bolsa frutificaram na redação da monografia para obtenção do Bacharelado, denominada "No Reino do 'maníaco de boa fé': A Quinta Monarquia de D. João de Castro (1597-1623)”. 
Salvo na opinião de José Eduardo Franco e Bruno Cardoso Reis, que viram no Tratado da Quinta Monarquia (1641), do Frei Sebastião de Paiva, "o primeiro grande esforço de elaboração teórica nascido da crença sebástica, assim como o primeiro texto em português de fundamentação apologética ao Quinto Império" "117, pode-se dizer que Castro é tido consensualmente como fundador do sebastianismo. Isso se deve, em larga medida, ao intelectual João Lúcio de Azevedo, que, no começo do século XX, batizou-o com o epíteto de "São Paulo", personagem bíblica que simboliza o empenho na disseminação do catolicismo pelo mundo. Outro aspecto digno de nota está contido na afirmação de que, entre aqueles que haviam conduzido Portugal à "demência coletiva do sebastianismo", Castro se enquadra mais como "maníaco de boa fé" do que "consciente embusteiro"118.

Algumas décadas depois, ainda a reboque das teses de Azevedo, o brasileiro Eduardo D’Oliveira França identificou na exegese castrista a acomodação das "profecias populares de Bandarra à causa do sebastianismo e da redenção portuguesa"119. Recentemente, outras perspectivas deram largada para novos questionamentos. Jean Delumeau ressaltou a influência da escatologia jesuítica na formação acadêmica, realizada em Évora, antes mesmo da partida do letrado para o exílio $^{120}$. Lucette Valensi enfocou o papel desempenhado pelo fidalgo no processo que transformou uma esperança difusa em "ideologia"121 . Diogo Ramada Curto pôs em destaque as "relações de microconflitualidade" 122 dentro da colônia de portugueses exilados na França, no que pese a polêmica de Castro com os antonistas e as desavenças com o frei Estevão de Sampaio. Jacqueline Hermann atribuiu ao bastardo a formulação de um messianismo responsável por, dali por diante, cristalizar a ideia do "Encoberto esperado ser o próprio D. Sebastião"123.

Para Martim de Albuquerque, o letrado ajudou a disseminar a nova crença graças às seguintes características: "inalterável capacidade de sofrimento", “estóico e

\footnotetext{
${ }^{117}$ FRANCO, J. E.; REIS, B. C. "Introdução”. In: PAIVA. F. S. Tratado da Quinta Monarquia. Colecção Pensamento Português. Lisboa: Imprensa Nacional-Casa da Moeda, 2006, p. 84.

${ }_{118}$ AZEVEDO, J. L. A Evolução do Sebastianismo. Lisboa: Livraria Clássica Editora, 1947, p. 45.

${ }^{119}$ FRANÇA, E. D. Op. cit., p. 249.

${ }^{120}$ DELUMEAU, J. Mil anos de felicidade: uma história do paraíso. Trad. São Paulo: Companhia das Letras, 1997, p. 185.

${ }^{121}$ VALENSI, L. Fábulas da Memória. A Batalha de Alcácer Quibir e o Mito do Sebastianismo. Trad. Rio de Janeiro: Nova Fronteira, 1994, p. 135.

${ }^{122}$ CURTO, D. R. "O Bastião! O Bastião". In.: Idem. Cultura Política no tempo dos Filipes. Lisboa: Edições 70, 2011, p. 54.

${ }_{123}$ HERMANN, J. No Reino do Desejado: a construção do Sebastianismo em Portugal - séculos XVI e XVII. São Paulo: Companhia das Letras, 1998, p. 206.
} 
orgulhoso desinteresse pelos bens materiais", "entranhado amor da pátria", "extraordinária tenacidade e lição de energia", "resistência à adversidade e amor ao ideal", "espírito poético e uma moral heróica"124. Quase com as mesmas palavras, ou apenas invertendo a ordem delas, na introdução ao Discurso, Aníbal Pinto de Castro asseverou o "generoso desprendimento dos bens materiais", além da "estóica e serena capacidade de sofrimento e o heroico sentido do sacrifício" ${ }^{25}$. Profundamente barroca, no entender do filólogo português, a obra de D. João de Castro é resultado da mescla entre "grandeza" e "loucura", ambas a serviço da "ancestral consciência dos deveres para com a Pátria" ${ }^{\prime 26}$. Nesta chave de leitura, é bom lembrar, o nacionalismo avant la lettre cumpre o papel de fomentar o anseio por autonomia política durante os sessenta anos de monarquia dual.

Portador de inteligência doentia ${ }^{127}$, São Paulo ${ }^{128}$, maníaco de boa fé, exegético apaixonado, ideólogo, sebastianista letrado, patriota, estóico, abnegado, impostor ${ }^{129}$, nobre decadente ${ }^{130}$ e clérigo exilado ${ }^{131} \ldots$ A imagem de Castro mudou e continuará mudando conforme as inquietações que o presente projetar sobre épocas pretéritas. A mais eficaz tentativa de oxigenação dos últimos tempos veio das mãos de João Carlos Serafim, responsável pela recente edição e publicação da Aurora da Quinta Monarquia (1604-1605), livro no qual, segundo o pesquisador, o fidalgo "enriquece a sua fundamentação bíblica e profética" e, de forma minuciosa, "tece os 'lugares vazios' e aperfeiçoa os contornos mais grosseiros"132. A "obra modelar" não havia sido publicada, durante os seiscentos, muito provavelmente em virtude dos altos custos, ou ainda por possíveis atritos do autor com o filho de D. Antônio, seu ex-protetor. Emendada em 1609, quando se acrescentaram o índice e pequenas notas marginais, ela se desmembraria, posteriormente, em favor de outros volumes, mais especificamente da

\footnotetext{
124 ALBUQUerQue, M. de. Estudos de Cultura Portuguesa. Lisboa: Imprensa Nacional-Casa da Moeda, 2000, pp. 304, 321, 322.

125 CASTRO. A. P. "Introdução". In: CASTRO, J. de. Discurso da Vida do Rey Dom Sebastiam. Reprodução fac-similada da edição de Paris (1603). Lisboa: Edições Inapa, 1994, p. 4.

${ }^{126}$ Idem, p. 10.

127 D'ANTAS, M. Os falsos D. Sebastião. Estudo sobre a história de Portugal. Trad. Francisco Sales Loureiro. Lisboa: Heuris, s/d, p. 156.

${ }^{128}$ Utilizada originalmente por Oliveira Martins, ainda no século XIX, a expressão foi erroneamente atribuída a João L. de Azevedo, autor d' A Evolução do Sebastianismo, obra publicada no começo do XX. ${ }^{129}$ SÉRGIO, A. "Interpretação não romântica do sebastianismo". In: Idem. Ensaios. Tomo I. Lisboa: Livraria Sá da Costa Editora, 1980, p. 243.

${ }^{130}$ DOBRORUKA, V. “Considerações sobre o pensamento trinitário de Joaquim de Fiore”. Revista Múltipla, Brasília, junho 2000, p. 9.

${ }^{131}$ SCHAUB, J. F. Op. cit., p. 58.

132 SERAFIM, J. C. G. Op. cit. Tomo II, p. 435.
} 
Segunda Parte da Paraphrase ${ }^{133}$ (1614), para onde migraram os capítulos 22 ao 26, e do Tratado dos Portugueses de Veneza ${ }^{134}$ (1621), receptor da autobiografia que originalmente compunha o vigésimo primeiro capítulo da Aurora.

O traço comum das interpretações sobre D. João de Castro é dado basicamente pelo patriotismo e resistência às dificuldades materiais. Tendo isso em conta, o presente trabalho tenta mostrar que, por um lado, o alegado apelo nacionalista deve ser substituído por uma espécie de anti-filipismo traduzido na formulação do sebastianismo enquanto projeto de destino coletivo, argumento incessantemente explorado desde o rompimento do letrado com D. Antonio, e tido pela historiografia, no mais das vezes, como protonacionalismo. Por outro, indicará para o fato das "misérias" e bastardia assumirem o estatuto de categorias políticas de extrema importância no seio da polêmica travada com o antonismo, haja vista a inexistência duma esfera pública onde as idéias pudessem ser debatidas sem que se levassem em consideração características que hoje se encontram no âmbito da vida privada. Daí a importância das tópicas ovidianas para a narrativa de experiências individuais emuladas a partir de personagens históricos e míticos no intuito de "ressuscitar" a esperança sebastianista face ao desalento representado pela União das Coroas Ibéricas e, sobretudo, pelo assassinato do D. Sebastião de Veneza, em quem o fidalgo depositou todas as suas esperanças.

\footnotetext{
${ }^{133}$ Assim conhecida em virtude da "primeira parte" ter sido publicada em 1603, na França. Ver nota 119 para localizá-la no índice geral dos 22 volumes depositados na Biblioteca Nacional de Lisboa (BNL).

${ }^{134}$ Ver nota 119 para localizá-lo no índice geral dos 22 volumes depositados na Biblioteca Nacional de Lisboa (BNL), e nota 199 para averiguar os procedimentos metodológicos para com a fonte em questão.
} 


\section{2. Sebastianismo: genealogia de uma crença}

[...] um dos nossos lemas deverá ser este: não, senhores, não nascemos sebastianistas, - e não queremos, positivamente não queremos, viver como se o fôssemos!

Antonio Sérgio, Interpretação não romântica do sebastianismo.

Além da cultura judaica, berço da idéia de redenção e "povo eleito", o messianismo marcou presença em povos da Babilônia e Egito. Entre os judeus, o messias assumiu o papel de guia espiritual, função transmitida, com o passar do tempo, para a figura de Jesus Cristo. Já impregnada ao imaginário cristão, tal noção fundamentaria crenças em torno de personagens míticos ou históricos, chamando atenção das mais diversas áreas do conhecimento humano. No campo da sociologia, o paradigma weberiano leu o messianismo como efeito da privação de liberdade política, premissa largamente utilizada, talvez até hoje, para explicar o surgimento e disseminação do sebastianismo bem como de outras correntes semelhantes. Nesta perspectiva, a socióloga brasileira Maria Isaura de Queiroz sustentou, no âmbito da modernidade portuguesa, o protagonismo da "reconquista da autoridade política"135 por meio do rompimento com a Monarquia Hispânica. Nos domínios da historiografia, entre inúmeros exemplos, José Van den Besselar também vinculou a crença sebástica aos momentos de aguda crise social ${ }^{136}$. Contudo, trabalhos como os de Marc Bloch, em Os Reis Taumaturgos, e Ernest Kantorowickz, nos Dois Corpos do Rei, deixam entrever manifestações messiânicas a serviço das monarquias franco-inglesas, relativizando, dessa maneira, a pretensa exclusividade do caráter contestatório e/ou revolucionário.

Difícil encontrar seu começo bem como decretar seu fim, o sebastianismo tornou-se um dos mais longevos fenômenos da cultura lusitana, tendo adquirido, segundo Antonio Machado Pires, duas dimensões: a expectativa pelo retorno do rei desaparecido e, numa acepção "culturológica", a confecção de um símbolo por meio do qual se expressariam as especificidades do ser português ${ }^{137}$. Nesta segunda esfera, o tema começou a ganhar destaque a partir de 1810, quando José Agostinho de Macedo publicou um opúsculo com o fito de denegrir os sebastianistas. No final da mesma centúria, Oliveira Martins caracterizou o movimento como "prova póstuma da

\footnotetext{
${ }^{135}$ QUEIROZ, M. I. P. de. O messianismo no Brasil e no mundo. São Paulo: EDUSP, 1965, p. 115.

${ }^{136}$ Cf. BESSELAAR, J. V. den. Sebastianismo - uma história sumária. Lisboa: ICLP, 1987.

${ }^{137}$ Cf. PIRES, A. M. B. M. D. Sebastião o Encoberto. Estudo e Antologia. Lisboa: Fundação Calouste Gulbenkian, 1969.
} 
nacionalidade". Como resposta, José Pereira de Sampaio deu à luz, já no século XX, a $O$ Encoberto. Em seguida, Miguel de Unamundo propôs um exercício de história comparada entre os ibéricos, concluindo que os portugueses eram mais inseguros que os espanhóis, e por isso teriam preferido esperar a vinda do messias. Nas Origens do Sebastianismo, de 1909, Costa Lobo destacou o caráter emancipador do movimento durante a monarquia dual. Em Demanda do Santo Graal, de 1922, Afonso Lopes Vieira sustentou uma religião do Encoberto diretamente atrelada ao "exílio da Amada Pátria".

Neste mesmo começo dos novecentos, o credo sebástico chegou a dividir a "Renascença Portuguesa" entre o bloco que denunciava o atraso do país e o que o reivindicava, de forma saudosista, como símbolo cultural. Antonio Sérgio, representante da primeira corrente, viu a expectativa em torno de um "romântico pedaço de asno" 138 como elemento externo à raça portuguesa, já que oriunda, segundo ele, das comunidades de origem judaica. Na Exortação à Mocidade, de 1924, Carlos Malheiro Dias deu início ao que se revelaria uma acalorada e extensa discussão em torno do legado do jovem monarca. A resposta viria na carta-prefácio da reedição de $O$ Desejado, onde Sérgio afirmava não enxergar o antigo soberano como exemplo de conduta para a juventude. Dias, por sua vez, chamou-o depreciativamente de "racionalista", tendo que suportar, na tréplica de Sérgio, a ridicularização de sua intransigente defesa ao rei cavaleiro. Nem mesmo as intervenções de Mário de Castro, autor de À Margem da Questão Sebástica, de 1925, e Preto Pacheco, que escreveu o opúsculo D. Sebastião - à margem duma polêmica, de 1928, conseguiram dar contornos definitivos ao debate.

Pouco tempo antes, em 1918, João Lúcio de Azevedo havia publicado a Evolução do Sebastianismo no intuito de traçar uma análise genealógica, além de estabelecer balizas temporais e referenciar fontes de grande importância para o estudo do movimento. Sob a chave interpretativa da nacionalidade, Azevedo destacou a esperança enquanto "feição inseparável da alma portuguesa"139, conferindo destaque para as trovas proféticas escritas pelo artesão Gonçalo Bandarra no final da primeira metade dos quinhentos. Acontece que a identificação do sapateiro como anunciador do Desejado nada mais é que o resultado da armadilha subjacente à Paraphrase $e$ Concordancia (1603), segunda e última obra publicada por D. João de Castro no exílio. Esta é, na verdade, a primeira reprodução tipográfica dos tais versos apocalípticos, e

\footnotetext{
${ }^{138}$ SÉRGIO, A. "Interpretação não romântica do sebastianismo". In: Idem. Ensaios. Op. cit., p. 241.

139 AZEVEDO, J. L. A Evolução do Sebastianismo. Op. cit., 8.
} 
consiste basicamente na cooptação da mensagem bandarrista ao discurso que apregoava o advento da monarquia universal encabeçada por D. Sebastião. Seja como for, a única tentativa de problematizar as relações entre Castro e Bandarra surgiria apenas em fins da década de 1990, mais de meio século após a primeira tiragem da Evolução.

O intelectual português afirmava ainda que os boatos acerca da possível sobrevivência do monarca não haviam se disseminado somente no "povo ignaro", mas também entre "homens atilados e de espírito culto"140. Extraindo o núcleo comum de um fenômeno essencialmente múltiplo, em fins do século $\mathrm{XX}$ a historiadora brasileira Jacqueline Hermann sustentou o intercâmbio entre a "cultura erudita e popular"141 como chave de leitura com poder de fogo para desbancar a visão de que o sebastianismo se expressaria exclusivamente em cenários de insatisfação aguda, crise ou convulsão social. Fruto de sua tese de doutorado, No Reino do Desejado representa, portanto, o ponto de viragem da historiografia que identificava na crença no retorno de D. Sebastião um mecanismo de autodefesa acionado somente nos contextos de tribulação política, sobretudo durante a modernidade. Nos horizontes da união das Coroas Ibéricas, a autora buscou conectar as duas pontas da pirâmide social portuguesa para encontrar em D. João de Castro e no sapateiro Bandarra verdadeiras amostras do substrato messiânico que teria ajudado inclusive na formulação da sacralidade da monarquia lusitana ${ }^{142}$.

Presente também na obra de Antonio Sérgio, outro aspecto da Evolução que continuaria a influenciar a historiografia é o que aborda a mescla cultural responsável pelo processo de mitificação do Desejado, com destaque para o elemento judaico, o "Encuberto" espanhol e, por fim, os contos lendários do circulo arturiano ${ }^{143}$. O aprofundamento da questão viria no começo dos anos 2000, quando a historiadora brasileira Ana Paula Torres Megiani identificou o surgimento do sebastianismo em meio a um "conjunto de expectativas muito antigas na Península Ibérica, bem anteriores ao século XVI" ${ }^{\prime 44}$. Mais do que a crença propriamente dita, sua dissertação de mestrado tem como epicentro os elementos formativos que acabaram por depositar uma espécie de infalibilidade na figura do neto e sucessor de D. João III, o Piedoso. Neste início de

\footnotetext{
${ }^{140}$ Idem, p. 88.

${ }^{141}$ HERMANN, J. No Reino do Desejado. Op. cit., p. 22.

${ }^{142}$ Recentemente, Evaldo Cabral de Mello buscou relativizar a hipótese do sebastianismo como proposta de sacralidade elaborada com o objetivo de compensar a ausência da unção papal nos rituais de coroação dos monarcas portugueses. Cf. MELLO, E. C. "À espera da redenção nacional”. In: Idem. Um imenso Portugal: história e historiografia. São Paulo: Editora 34, 2002, pp. 346-347.

${ }^{143}$ AZEVEDO, J. L. A Evolução do Sebastianismo. Op. cit., p. 9.

${ }^{144}$ MEGIANI, A. P. O Jovem Rei Encantado: Expectativa do Messianismo Régio em Portugal, Séculos XIII a XVI. São Paulo: Hucitec, 2003, p. 12.
} 
século XXI, e ainda numa perspectiva de longa duração, Joaquim Domingues ressaltou a longevidade do providencialismo histórico em voga pelo menos até que Alexandre Herculano colocasse abaixo as concepções religiosas sobre as quais se assentavam a maior parte das narrativas sobre as origens e o destino do reino ${ }^{145}$.

Recuando até a década de 1940, vale destacar o esquema proposto por Luís Chaves em O Sebastianismo, Mística da Restauração. Segundo ele, a história do fenômeno pode ser dividida em três. A primeira etapa, o "pré-sebastianismo", abarca as trovas do sapateiro Bandarra vindas a público ainda na primeira metade dos quinhentos. A segunda, intitulada "sebastianismo real", compreende as apologias em torno do jovem monarca, quando ainda vivo, através das obras de Luís de Camões, Diogo Bernardes e Antonio Ferreira. O último estágio, chamado de "sebastianismo profético" ou "póssebastianismo", refere-se ao período da dominação filipina, quando o movimento recrudesce, passando pela Restauração, período em que acabou se confundindo com o messianismo brigantino, e daí por diante em rápidos surtos que se estenderam até o começo dos oitocentos. O exilado D. João de Castro, diga-se de passagem, está no começo desta terceira etapa, a se seguir o modelo de Chaves ao pé da letra.

Esboçada na obra de Costa Lobo, a faceta política do messianismo português apareceu de forma mais acabada na obra intitulada Literatura autonomista sob os Filipes, de 1941. Nela, Hernani Cidade afirmou que o caráter emancipatório do "misticismo messiânico" fomentava o anseio pelo término da "forçada ligação na monarquia dual" $"$. Com o mesmo enfoque, nos anos sessenta Joel Serrão destacou a "índole política" "147 do movimento que teria ajudado a disseminar o que até então não passava duma sublevação aristocrática, em referência ao levante de 1640. Opinião semelhante teve João Carlos Serafim ao detectar "claras inferências políticas" 148 num sebastianismo surgido como dissidência da causa antonista, enquanto José Veiga Torres levantou a bandeira da resistência à exploração social ${ }^{149}$. O francês Yves Marie Bercé encontrou na história comparada a figura do monarca redentor que povoou o imaginário popular em países como Portugal, Rússia e França durante praticamente toda a

\footnotetext{
${ }^{145}$ Cf. DOMINGUES, J. De Ourique ao Quinto Império: para uma filosofia da cultura portuguesa. Lisboa: Imprensa Nacional-Casa da Moeda, 2002, pp. 333-336.

${ }^{146}$ CIDADE, H. Op. cit., p. 177.

${ }^{147}$ SERRÃO, J. Do sebastianismo ao socialismo. Lisboa: Livros Horizonte, 1983, p. 19.

148 SERAFIM, J. C. G. "D. João de Castro (1550? - 1628?)". Op. cit., p. 139.

149 TORRES, J. V. "Um exemplo de resistência popular: o Sebastianismo". Revista Crítica de Ciências Sociais, $\mathrm{n}^{\mathrm{o}} 2$, set.-dez., p. 6.
} 
modernidade ${ }^{150}$. A recente leitura do também francês Jean-Frédéric Schaub só fez reforçar o sebastianismo enquanto "recurso político"151 com fins de desestabilização da ordem filipina em Portugal.

No sentido inverso, historiadores como José Eduardo Franco e Bruno Cardoso Reis afirmaram categoricamente que a plena confiança na providência divina "leva a que os sebastianistas não se empenhem numa acção política concreta no sentido de modificar a ordem estabelecida como sucedeu com outras correntes messiânicas" ${ }^{\text {"152 }}$. Na mesma linha de raciocínio, embora preocupado com questões vinculadas ao mundo jurídico, Antonio Manuel Hespanha viu no suposto conservadorismo sebástico a "fuga interior do misticismo e do visionarismo" ${ }^{153}$. Antes deles, porém, no começo da década de 1950, o historiador brasileiro Eduardo D’Oliveira França já havia apontado nesta direção ao propor um tipo ideal de fidalgo melancólico e inerte. Segundo o autor de Portugal na Época da Restauração, o sebastianismo

[...] foi o derivativo de uma geração traumatizada, incapaz de ação, melancólica e pessimista, quando não sentiu mais poder contar com o próprio valor. Uma rendição ao fatalismo [...] uma mística de homens tristes que descreem de suas próprias forças. Condenação à expectativa - relaxamento das energias numa expectativa providencial. Entendamos. $O$ sebastianismo paralisou a fidalguia portuguesa ${ }^{154}$.

Com a mesma ideia, em linhas gerais, Martim de Albuquerque fincou suas análises na "mística patriótica"155, reforçando o protonacionalismo impregnado ainda hoje em interpretações que despejam o fardo histórico da formação do Estado numa época em que os debates políticos não estavam postos nestes termos e, pior, sobre uma crença que, ao contrário, deve ser entendida por meio das redes clientelares sobre as quais se assentavam todo e qualquer tipo de relação social no Antigo Regime lusitano e quiçá europeu. Exemplo disso é a afirmação de que Alcácer Quibir significa

A perda da autodeterminação do povo português como epílogo desastroso de uma época áurea da história de um país que tinha erguido um império tão universal e decisivo para a inauguração de uma nova era de relações entre os povos, em que tantos sonhos e glórias se condensaram de forma tão intensa,

\footnotetext{
${ }^{150}$ Cf. BERCÉ, Y. M. O Rei Oculto: salvadores e impostores. Mitos políticos populares na Europa Moderna. Bauru, SP: EDUSC-Imprensa Oficial do Estado, 2003.

${ }^{151}$ SCHAUB, J. F. Op. cit., p. 60.

${ }^{152}$ FRANCO, J. E.; REIS, B. C. Op. cit., p. 112.

${ }^{153}$ HESPANHA, A. M. "Conflito e resistência na sociedade do Antigo Regime". In: Idem. Caleidoscópio do Antigo Regime. Op. cit., p. 57.

${ }^{154}$ FRANÇA, E. D. Op. cit., pp. 230-231.

${ }^{155}$ Cf. ALBUQUERQUE, M. de. Op. cit., p. 318.
} 
[deixando] na consciência patriótica do reino lusitano uma sensação de incumprimento da missão histórica de Portugal. O mito do sebastianismo que germina neste contexto é a mais significativa resposta a este sentimento de frustração aguda ${ }^{156}$.

"Autodeterminação" e "consciência patriótica", por exemplo, são termos pesados demais para aquele contexto, talvez inócuos para explicar o sebastianismo quer na sua totalidade, se é que há, quer nas suas manifestações mais específicas. É mais apropriado ver a mitificação do Desejado por meio do registro profético que confere sentido unívoco aos destinos de D. Sebastião, Portugal e do exilado D. João de Castro, sabidamente um dos principais responsáveis pela criação do mito. Mesmo o silenciamento do letrado diante de um hipotético retorno, haja vista a inexistência de impedimento oficial para que isso ocorresse, deve ser inscrito neste tipo de narrativa, pois soaria pouco desejável uma volta para a terra natal antes da ascensão do rei messias ao império universal através duma apoteótica consagração em Lisboa. Indissociável do monarca e do reino, o desterro de Castro acabaria quando também tivesse fim a União das Coroas Ibéricas e o exílio mítico de D. Sebastião - leia-se Marco Túlio Catizone, o impostor de Veneza.

Mais do que isso, o poder de fogo da crença sebástica pode ser atestado pela quantidade de envolvidos nos conluios ocorridos tanto dentro quanto fora do reino, com destaque para as reações das autoridades locais. Rápidas e severas, elas objetivaram conter a desestabilização da ordem filipina a qualquer custo. Caso contrário, em fins do século XVI e início do XVII, os impostores de Penamacor, Ericeira, Madrigal e Veneza teriam sido tratados como o falso D. Sebastião dado a conhecer na baixa de Lisboa no ano de 1813: um louco, excêntrico, mais merecedor do sanatório que a recondução ao posto que julgava um dia ter ocupado. Vale dizer, por fim, que a alegada "longa duração" do movimento pode ofuscar seu caráter mais profundamente político, visto que, gradativamente, o mundo das artes em geral tornou-o símbolo de uma época ou de um país. Ainda hoje, portanto, a seguinte pergunta deve ser feita: é o sebastianismo, afinal de contas, a modalidade messiânica mais célebre e "bem sucedida" em relação a todas as outras da cultura portuguesa, ou, ao contrário, todas as outras são variações opacas do culto a D. Sebastião?

\footnotetext{
${ }^{156}$ FRANCO, J. E.; REIS, B. C. Op. cit., p. 77.
} 


\section{Capítulo 3 - O exílio moderno português através das tópicas ovidianas}

E todo o que em terras longínquas se retarda, faça ele o que fizer, está exilado dos pátrios lares; não importa muito se é por força de lei promulgada por tirano que se encontra no exílio, se por sua própria vontade.

Diogo Pires, A Benesso.

Aqui se investiga o fenômeno do exílio a partir duma mesma conformação histórica na qual indivíduos de mundividência coeva puderam refletir em condições sociais minimamente semelhantes. Para isso, recorre-se às tópicas ovidianas que, ao longo do tempo, consolidaram o tema enquanto vertente literária, articulando-as com aspectos das trajetórias individuais apreendidos do ato da escrita em terras estrangeiras. Trata-se, portanto, de uma análise documental que busca reter os sentidos do desterro a partir dos "lugares comuns" que, consciente ou inconscientemente, ambos os autores tiveram de visitar para se fazerem entender aos olhos do público e da audiência que tinham em mente.

\subsection{Ovídio cristianizado: método figural de exegese histórica}

Metáfora empregada para representar os sinais do advento da Quinta Monarquia, a Aurora traria consigo os primeiros raios de um sol ainda encoberto, representado, por sua vez, pelo também encoberto D. Sebastião ${ }^{157}$. Em linhas gerais, a utilização da alegoria da natureza acaba ilustrando o próprio tema da obra:

Quem ha, a quem a Manhaam em começando de romper, não alegre todos os espíritos, inda que não amanheça de todo? Ou qual he o dia, por mais fermoso que seja, que não tenha sua manhaam? tão graçiosa muytas vezes, como aparece depois em sua fermosura. Costuma romper a Alva primeiro, de claridade em claridade, ate nasçer o sol com os rayos emnevoados, pareçendo que não pode abrir os olhos como dorminhoco. Depois desempeçandoos das nuvens, e resplandeçendo em sua força pello universo; não ha ja quem se lembre da manhaam, com a fermosura do dia. E com muyta razão: por que não tem entre si nenhuã comparação, pois elle he o porque se espera, e o que enche

\footnotetext{
${ }^{157} \mathrm{O}$ título também pode ter sido inspirado num vaticínio da literatura pseudo joaquimita, aquela que se atribui ao abade Joaquim de Fiore, chamado por D. João de Castro de "profeçia a El Rey Sol encuberto"; ou na obra do monge Cirilo ou ainda na revelação de Santo Anselmo que dava conta de "um sol que vem de cima", em alusão ao monarca que derrotaria o Antipapa. Cf. CASTRO, J de. A Aurora da Quinta Monarquia (1604-1605). Introdução e Edição: João Carlos Gonçalves Serafim. Supervisão Científica: José Adriano de Freitas Carvalho. Porto: CITCEM - Edições Afrontamento, 2011, p. 237-238, 329-330.
} 
os desejos dos Mortaes: e ella não he que huã Alvorada que lhes da do comprimento, e chegada delles ${ }^{158}$.

De acordo com o trecho, Castro se propunha detectar, ou "desencobrir", as felicidades prometidas ao povo cristão, sobretudo o português, revelando assim as benesses advindas com o sol que, pouco a pouco, dissiparia as sombras para desnudar formas e volumes que a penumbra não deixava mostrar por inteiro. "De claridade em claridade", segundo suas palavras, a nitidez das imagens se tornava proporcional às expectativas por um futuro cada vez menos distante, cada vez mais próximo, presente. Ainda no registro da metáfora, o início do dia só poderia ser contemplado pelos que acordassem cedo, talvez na madrugada, e se colocassem a observar, nos mínimos detalhes, os segredos da natureza, percebendo de que maneira a emanação da luz no céu iluminaria todas as coisas na terra. Ao contrário dos que acordassem em meio à plenitude da manhã, a estes homens escolhidos estaria reservada a revelação do processo que transforma noite em dia, escuridão em claridade, dificuldades em bênçãos.

A despeito do otimismo, a mitologia esconde uma lenda que Castro talvez não fizesse idéia da existência, ou, ao contrário, recuperou-a para subverter seu sentido original. A versão greco-latina fala numa deusa Aurora, irmã da Lua e do Sol, que se encantou pelo belo Titono, filho do rei dos troianos, tendo raptado-o para com ele se casar. Da relação nasceria Mêmnon, destemido combatente ao lado da família paterna na Guerra de Tróia - ocasião em que teria conseguido afugentar o exército grego até a chegada de Aquiles, quando a batalha conheceria seu desfecho. Mesmo distante, a mãe acompanharia o desenrolar dos acontecimentos até a trágica morte do filho, e, à guisa de luto, pelas manhãs passou a derramar suas lágrimas (em forma de orvalho) sobre a vegetação dos campos ${ }^{159}$. Outrora ou embora triste, na versão sebastianista a Aurora clássica se transforma em prelúdio da bem aventurança, agregando ao título da mais importante obra de D. João de Castro a idéia de redenção dos males que teriam afligido Portugal desde as duas últimas décadas dos quinhentos.

A partir deste mote, pode-se afirmar que o aspecto figurado da e na Aurora ${ }^{160}$ ditou a compreensão do letrado sobre toda e qualquer ação humana, desde os tempos da

\footnotetext{
${ }^{158}$ Idem, p. 38.

159 BULFINCH, T. O Livro de Ouro da Mitologia (A Idade da Fábula): histórias de deuses e heróis. Trad. Rio de Janeiro: Ediouro Publicações, 2002, p. 249-251. Para o mito na versão grega, ver os verbetes "Éos" e "Mêmnon". Cf. GUIMARÃES, R. Dicionário da Mitologia Grega. São Paulo: Cultrix, 1982, p. 136 e 217.

${ }^{160}$ Não há menção a este recurso nas obras anteriores, exceção feita ao trecho da Paraphrase em que se esboçou, nos termos de uma concordia litterae, as similitudes entre Moisés e D. Sebastião e judeus e
} 
criação até o instante em que escrevia e, por conseguinte, até o futuro mais distante, o Juízo Final. Por figuração, é bom frisar, utiliza-se aqui a conceitualização de Erich Auerbach, que define a "figura como algo real e histórico que anuncia alguma outra coisa que também é real e histórica" ${ }^{\text {161 }}$. A raiz deste procedimento encontra-se na articulação de dois ou mais eventos por meio da associação de símbolos e personagens do Antigo com os do Novo Testamento ${ }^{162}$. Sempre à espera de preenchimento histórico, a figura consegue encadear personagens e cenários numa trama linear e (retoricamente) controlada, do princípio ao fim, pelos desígnios divinos ${ }^{163}$. No caso do sebastianismo, seu discurso teológico-politico buscou concatenar a União das Coroas Ibéricas com o mais remoto evento da história nacional, conhecido como milagre de Ourique, no intuito de definir o papel da monarquia portuguesa no âmbito do império universal.

Dois exemplos ilustram tais afirmações. O primeiro se refere à relação que Castro estabeleceu entre o fundador do reino português e D. Sebastião, figuração que espelha o mito de origem a partir da "horrenda tribulação" de 1578 e vice versa. A alusão a Ourique não era exatamente uma novidade naquele momento, já que, segundo Ana Isabel Buescu, o dito milagre havia se tornado parte significativa do processo de sacralização da monarquia que atingiu seu ápice durante o reinado de D. Manuel (14951521), monarca responsável pela construção de um novo túmulo para D. Afonso Henriques no Mosteiro de Santa Cruz de Coimbra ${ }^{164}$. Promessa basilar para a crença no destino anunciado nos primórdios da reconquista cristã, a D. Afonso teria sido garantida a proteção de sua dinastia até a $16^{\mathrm{a}}$ geração, a do Desejado; tendo sido o desastre

portugueses. Além disso, nela narram-se os sinais prodigiosos ocorridos numa ermida construída em homenagem ao mártir católico homônimo do monarca, localizada em Ourique, onde, em 1139, D. Afonso Henriques vencera os infiéis para se tornar o primeiro rei de Portugal. Numa das manifestações sagradas, a estátua do mártir teria começado a suar em virtude de um pão de cera que um ex-degredado oferecera em sua homenagem. Após a Aurora, o método se fez presente em todos os manuscritos, com destaque para a Segunda Parte da Paraphrase, os Paineis Divinos e o Tratado das Ordens.

${ }_{161}^{61}$ AUERBACH, E. Figura. São Paulo: Ática, 1997, p. 27.

162 A este respeito, Castro diz haver no "Testamento Velho muytas, e muy grandes figuras, e copiosissimas profeçias pellos Prophetas Sagrados". In.: CASTRO, J. de. A Aurora da Quinta Monarquia (1604-1605). Op. cit., p. 416.

${ }^{163}$ A figura pode manter relação com o que o historiador inglês Quentin Skinner chamou de "método escolástico tradicional de comentários à Bíblia", que consistia basicamente na reunião de passagens sem clara relação entre si com "a finalidade de extrair alguma lição genérica ou artigo de fé". Cf. SKINNER, Q. As Fundações do Pensamento Político Moderno. São Paulo: Companhia das Letras, 1996, "O Humanismo e a erudição bíblica”, p. 228.

${ }^{164}$ Cf. BUESCU, A. I. "A Memória das Origens. Ourique e a fundação do reino (séculos XV-XVIII)". In: Idem. Memória e Poder. Ensaios de História Cultural. Lisboa: Edições Cosmos, 2000, pp. 16-18; VALENSI, L. Fábulas da Memória. Op. cit., p., Cap. VI, Item 2, "De Ourique a Alcácer", pp. 140145.Ver também o artigo em que Luís Filipe Silvério Lima analisa a iconografia seiscentista do milagre a partir da representação dos sonhos. Cf. LIMA, L. F. S. "Imagens e figuras de um rei sonhador: representações do Milagre de Ourique e do juramento de Afonso Henrique no século XVII". Revista de História, São Paulo, v. 26, nº 2, 2007, p. 311-339. 
africano anunciado, portanto, ao "primeiro Real progenitor"165. Ligando os extremos de um enredo concebido a partir de figuras que se anunciam mutuamente, o discurso providencialista da Quinta Monarquia acabou por atribuir à vida dos homens funções históricas equivalentes, do mais alto ao mais baixo nível da pirâmide social.

O segundo exemplo, na verdade, se desdobra em aspectos auto-representativos que estabelecem nexos entre as experiências individuais, de cariz biográfico, e as teses sustentadas por toda a Aurora ${ }^{166}$. Nas passagens que tratam do pretendente D. Antonio é possível detectar a opinião do autor sobre os impactos de seus constantes deslocamentos pela Europa. Em relação ao exílio, portanto, o letrado afirmou que o partido antonista teria deixado "muytos desterrados, e perdidos, e acabando fora de sua Patria, sem se poderem nunca restaurar, por mais que fizessem" "167. A construção da imagem pejorativa do Prior do Crato, a ele atribuindo a "causa da ruina do Reyno" e "vinda do cativeiro e do mal que com ella se seguio", opera enquanto conciliação dos últimos acontecimentos, no cenário político, com planos e aspirações pessoais. Assim como aconteceria com outros exilados portugueses, que "hão de ir de fora ao mesmo Reyno, a restaurallo" ${ }^{\text {168 }}$, é possível dizer que Castro assumiu para si (e, por ventura, para os demais em igual situação) papel de destaque na retomada da liberdade perdida desde a morte do Cardeal D. Henrique, o último rei natural.

$\mathrm{Na}$ parte dedicada às concórdias dos Testamentos, Novo e Antigo, é possível encontrar a associação do "São Paulo" do sebastianismo com o evangelista Matheus, um dos responsáveis pela história dos sucessores do rei Davi até o cativeiro da Babilônia. Nesta ocasião, Castro sustentou que o reino apresentava os mesmos 14 monarcas da contagem bíblica quando da "transmigração da Berberia ou de Castella"169. Para isso, teve que excluir 3 reis, a saber: D. Henrique, por fazer Portugal "de livre a sogeita" $" 170$, D. Sancho, recusado pelos "vicios de seus privados"171, e D. Fernando, que teria roubado a "molher a seu marido". Comentando o "Oráculo Sibyllino", o letrado destacou o "pouco poder Del Rey Dom Sebastião: ate que ajunte os Profugos, que

\footnotetext{
${ }^{165}$ CASTRO, J. de. A Aurora da Quinta Monarquia (1604-1605). Op. cit., p. 63.

${ }^{166}$ Ainda sob o argumento figurado, no Tratado Apologético, de 1620, Castro se defenderia da acusação de bastardia dizendo que muitas das mais célebres personalidades portuguesas tinham tido a mesma origem "ilegítima", inclusive alguns de seus coetâneos. Cf. SERAFIM. J. C. G. Op. cit., Tomo I, p. 12.

${ }^{167}$ CASTRO, J. de. A Aurora da Quinta Monarquia (1604-1605). Op. cit., p. 476.

${ }^{168}$ Idem, p. 477.

${ }^{169}$ Idem, p. 94.

170 Ibidem.

${ }^{171}$ Ibidem.
} 
significam os que andam fogidos e desterrados das suas Pátrias, por longes terras" ${ }^{172}$. Profugo, lembra o autor, era o nome dado aos lusitanos residentes nas Índias Orientais bem como aos hereges. Além disso, há algum tempo o termo vinha sendo empregado como sinônimo de exilado ${ }^{173}$. Trocando em miúdos, um Castro dividido entre o medo do esquecimento e as expectativas de redenção acabou condicionando a imagem do Desejado, neste caso fragilizada, pois atrelada ao impostor Marco Túlio Catizone, o D. Sebastião de Veneza, à sua própria experiência de errância pelo continente europeu.

A vinculação de figuras cristãs consigo mesmo ou com outros personagens da cultura portuguesa traz em seu bojo uma série de representações sobre a biografia do autor. A hipótese segundo a qual o letrado teria manejado o "vasto espólio de textos proféticos [...] como um instrumento de leitura dos traumas pessoais e políticos" ${ }^{174}$, como se a Providência a ele designasse infortúnios e felicidades na mesma medida que a Portugal e D. Sebastião, pode ser atestada no instante em que o fidalgo acreditou dar publicidade, pela primeira vez, às revelações do compatriota Beato Amadeu ${ }^{175}$, radicado grande parte da vida na atual Itália. Nesta passagem, a falta de "mereçimentos" e os "grandissimos desmeritos" do religioso "exilado" compõem o argumento que reivindica honrarias supostamente reservadas aos pequeninos, tal qual o sapateiro Bandarra, o Desejado e, através do recurso da personificação, o genésico solo. O certo é que, empregado com objetivos precisos, a "desvalorização" se inscreve numa estratégia discursiva que sempre que possível ameniza o estigma da bastardia através do ofício da escrita, um dos meios de ascensão social no Antigo Regime ${ }^{176}$.

Dentre as figuras emuladas, a mais importante, do ponto de vista do exílio, é a do ermitão ${ }^{177}$ que, segundo a lenda, profetizara a D. Afonso Henriques a vitória sobre os mouros ainda na primeira metade do século XII. Castro lamentava o descuido para com

\footnotetext{
${ }^{172}$ Idem, p. 462.

${ }^{173}$ Cf. ANDRÉ, C. A. Mal de Ausência. Op. cit., p. 187.

${ }^{174}$ SERAFIM, J. C. G. "D. João de Castro (1550? - 1628?)". Op. cit., p. 139.

175 CASTRO, J. de. A Aurora da Quinta Monarquia (1604-1605). Op. cit., p. 413.

${ }^{176}$ Cf. HESPANHA, A. M. "A mobilidade social na sociedade de Antigo Regime". Revista Tempo, s/l, v. 11, n 21, 2006, p. 121-143.

${ }^{177} \mathrm{Na}$ documentação espanhola referente ao impostor de Veneza consta uma missiva enviada pelo Conde de Lemos, vice-rei de Nápoles, ao monarca Filipe II, dando conta de "un hermitaño de mas de 90 años com uma barba larga y blanca, que traya abito pardo se llego alli y le dixo que Dios le avia revelado que el era Rey don Sebastian, y que com tantas cosas como le dixeron de dezir que lo era". Vale lembrar que D. João de Castro visitava com relativa frequência um famoso ermitão que vivia nas cercanias de Paris ganhando a vida com suas previsões sobre o futuro. Cf. CASTRO, J. de. Discvrso da vida do sempre bem vindo, e apparecido Rey D. Sebastiam, o Encuberto des de seu nascimento ate o presente: Feito, e derigido por D. João de Castro aos Tres Estados do Reyno de Portugal. Paris, impresso por Martin Verac, 1602. (cópia do exemplar impresso). Biblioteca Nacional de Lisboa - BNL, cód. 399, p. 60 r. Apud: SERAFIM, J. C. G. Op. cit., Tomo I, p. 267; "Conde de Lemos, Nápoles, 10 de Maio de 1601". Arquivo Geral de Simancas, Estado, maço 1097 - 123; 124. Apud: Idem. Tomo II, p. 314.
} 
o dito personagem, pois quase nada se sabia sobre sua "profissão, vida, santidade e fim"178 além da passagem do juramento na qual o próprio afirmava ter vivido 66 anos no desterro antes de ter podido anunciar "tamanhas maravilhas" ao então Conde. Aliadas ao desterro, a orfandade do "Santo Velho" (análoga, aliás, a do profeta Samuel) e a bastardia do fidalgo os inserem, tanto um como outro, no cíclico movimento de anunciação que lograva conectar Ourique a Alcácer Quibir através do partilhamento de atribuições históricas de considerável relevância para o destino do reino. Se a isso se acrescentar a afirmação de que, para comunicar suas bênçãos, o Criador se valeria de "hu Propheta Portugues sem pay nem may, e sem começo, e fim, que se delle saiba" ${ }^{179}$, a ambos estaria reservada a dádiva de garantir o triunfo de Afonso ou Sebastião; e, ainda mais, os sucessos da cristandade, já que as "venturas que Bandarra annunçia de quem socede a El Rey João; essas mesmas [...] annunciou em nome de Deus o Santo hermitão ao Conde Dom Affonso" 180 .

Publicado dois anos antes da Aurora, o Discurso da vida do sempre bem vindo e apparecido Rey D. Sebastiam fazia referência ao fato do monarca, durante seu "exílio mítico", ter escolhido "a companhia de hu santo hermitão, em a qual esteve algu tempo aproveitando em virtudes naquela vida solitaria [...]”. Logo abaixo, diz-se ainda que o tal ermitão exilado teria sido o porta-voz da mensagem celeste que garantia o retorno do Desejado ao trono que os espanhóis lhe haviam supostamente usurpado. Nos Notandos Vários, manuscrito sem data definida, afirma-se que o lendário Thelesforo de Cosença não passava de um "santo hermitão" portador de revelações divinas. A partir destas analogias, com destaque para o sentido proposto na Aurora, é possível sustentar que os subterrâneos dos escritos sebastianistas revelam a presença da tópica ovidiana que consiste, em linhas gerais, na "funcionalização da memória" por meio de "exemplos míticos ou históricos"181 - quer de personagens também exiladas quer não. A peculiaridade da obra castrista, contudo, reside nos atributos religiosos de figuras seculares que, na economia do texto, operam na lógica do aprimoramento do missionarismo católico atribuído a Portugal, como se a cada geração a tarefa tivesse de ser referendada e ampliada pela mesma Providência que garantira o êxito de 1139 .

Para além da referência indireta a Ovídio, é mister ressaltar que a busca de respostas para as agruras do exílio, neste contexto, passa obrigatoriamente pela premissa

\footnotetext{
${ }^{178}$ CASTRO, J. de. A Aurora da Quinta Monarquia (1604-1605). Op. cit., p. 56.

179 Idem, p. 57.

${ }^{180}$ Idem, p. 62.

${ }^{181}$ ANDRÉ, C. A. Mal de Ausência. Op. cit., p. 83.
} 
de que Deus "tem de costume descobrir [...] cousas antes de as fazer, pera ensinar aos homes a se conheçerem, e ao reconheçerem, e como tudo vem de sua mão" ${ }^{\text {182 }}$. Por essência, o discurso profético buscava mostrar a pequenez humana diante da atemporalidade e plenitude de um Divino que ora dava a conhecer suas revelações e ora as escondia "em veos: e outras de todo escuras"183. O desvendar dos mistérios da fé estaria incumbido aos profetas canônicos, os bíblicos, e não canônicos, os seculares, pois aquilo que o "Senhor revellou escuramente por São João, e pellos Prophetas Sagrados: declarou por outros servos seus, sendo hu delles Bandarra"184. Em outras palavras, Castro deveria, enquanto exegeta, adequar sua leitura das fontes e sua capacidade dedutiva ao contexto político-social mais amplo, a União das Coroas Ibéricas, sabendo de antemão que a "declaração dos tempos" é o "mais intrincado labyrintho de todos" ${ }^{185}$, e se desvendaria apenas em partes, nunca inteiramente, através de figuras com exata razão de ser e estar.

Ao contrário dos "aconteçimentos como cousa de historia", seria próprio da profecia "descontinuar, e interromper per muyto a meude; dando grandes saltos, e antepondo, e pospondo, segundo o que parece ao Espirito Santo"186. Vê-se aqui, de forma clara, a história como linha contínua de fatos que prescinde de transcendentalidade e por isso não consegue dar sentido aos eventos terrenos. Ao contrário, o profetismo conferiria roupagem extraterrena à vontade humana, esta refletida a partir da de um Deus que, via de regra, ocultava seus desígnios ${ }^{187}$. Do confronto das duas idéias Castro pôde dizer que as "Propheçias não são historias pera que se hajam de enfiar sempre nellas os acontecimentos"188, sobrepondo assim a essência divina à causalidade banal como forma de aumentar as chances de conhecimento da Causa Maior. Noutra ocasião, o autor afirmou não querer interpretar as "Profeçias pollos da minha nação, torçendoas á posta: não ganharei porisso nada pera elles, nem tirarei aos outros hu fio do que se lhes promete" ${ }^{\text {189; }}$; deixando claro sua opção

\footnotetext{
182 CASTRO, J. de. A Aurora da Quinta Monarquia (1604-1605). Op. cit., p. 474.

183 Ibidem.

184 Idem, p. 172.

185 Idem, p. 234.

${ }^{186}$ Idem, p. 237.

${ }^{187} \mathrm{O}$ interesse pelas profecias, sobretudo as atribuídas a Joaquim de Fiore, surgirá no intuito de embasar o rompimento com o Prior do Crato, em 1587. A partir daí, o letrado seguiria de perto dogmas joaquimitas como a divisão trinitária de tempo, originalmente concebida com o fito de enfraquecer o agostinianismo.

${ }^{188}$ CASTRO, J. de. A Aurora da Quinta Monarquia (1604-1605). Op. cit., p. 308.

${ }^{189}$ Idem, p. 468.
} 
pela exegese, e não pela anunciação, de toda sorte de literatura profética, objetivo que de fato norteou sua tratadística desde o rompimento com D. Antonio.

A partir do estatuto de exegeta, portanto, o letrado apreciou os "juízos de varias cousas" do célebre Nostradamus, tendo acusado-o de plágio e de prognósticos baseados em conhecimentos astrológicos "escurissimos e no mesmo grau ambíguos"190. O autor das rimas francesas também teria incorrido no erro de alterar o sentido "original" de certos vaticínios ao mesclá-los às suas próprias reflexões, o que leva a pensar na possibilidade do fidalgo português ter percebido as diferenças entre os escritos de sua autoria e os dos inúmeros "santos padres" que haviam se tornado referência para a exegese sebástica do início dos seiscentos. Se a publicação da Paráfrase (1603) do Bandarra significa a "opção definitiva de Castro pela interpretação profética da saga sebastianista" ${ }^{" 191}$, como sustenta Jacqueline Hermann, as figuras cristãs e o mito inacabado da Aurora tiveram de escolher o meio pelo qual seriam atualizados e (re)contados a partir do cenário da monarquia dual. Em suma, do embate com o que se entendia por narrativa histórica, a profecia parece ter saído vencedora.

\section{2. Vergonha e mofinas: o sofrimento como legitimação discursiva}

O temor de conhecer destino semelhante ao do ermitão que havia morrido sem deixar por escrito sua história fez com que Castro dedicasse parte de sua obra mais importante a uma espécie de autobiografia. Mais perto do fim da vida, e "vendo que podia morrer", segundo o autor, "sem dizer duas palavras sobre minhas cousas"192, no texto que originalmente compunha o vigésimo primeiro capítulo da Aurora ${ }^{193}$ o fidalgo empreendeu grande esforço no sentido de superar o limbo reservado aos homens que, como visto, teriam desempenhado no passado o mesmo papel que ele julgava desempenhar na virada do século XVI para o XVII.

Já no início do livro o escritor alertava os "varões de letras" acerca das opiniões de quem tinha "pouco ou nenhu estudo", afirmando também que "Por amor dos

\footnotetext{
${ }^{190}$ Idem, p. 186.

${ }^{191}$ HERMANN, J. No Reino do Desejado. Op. cit., p. 205.

192 CASTRO, J. de. Tratado dos Portugueses de Veneza ou Ternario, Senario, e Novenario dos Portugueses, que em Veneza solicitaram a liberdade d'El Rey Dom Sebastião Nosso Senhor. Com mais huã breve mençam do Senhor D. Antonio. Biblioteca Nacional de Lisboa (BNL), cód. 4387-88, fl. 424.

${ }^{193}$ Para efeito metodológico, vale ressaltar que, embora sacado dos originais em 1621 (18 anos, portanto, após o término da obra), o Tratado dos Portugueses de Veneza é aqui considerado como parte integrante, orgânica e indispensável da Aurora.
} 
pequenos dobramos muytas palavras, e nos detemos em muytas meudezas: o que não fizeramos, se não ouveramos somente com os criados na Academia"194. No âmbito do sebastianismo castrista, o "amor aos pequenos" pode ser tanto a busca dos interesses do próprio fidalgo, no afã de expor e, no fundo, atribuir sentido de redenção aos elementos depreciativos de sua trajetória (como, entre outros, a bastardia), quanto uma possível alusão ao fortalecimento da rede clientelar montada fora de Portugal em apoio a Marco Túlio, o falsário de Veneza - simbolizando aqui o início da vitória dos "nanicos" lusitanos sobre os "gigantes" espanhóis. Buscando extrapolar os limites "acadêmicos", mas ainda de maneira pseudo depreciativa, lá pela metade da Aurora, no começo da referida biografia, o exilado afirmava não querer

[...] oferecer de mi grandes façanhas, gabos, e louvores pois nada disso tenho. Somente quero deixar em memoria a pouquidade de minha pessoa, e de minha fortuna, com a pouca valia minha. [...] Como eu não sou Rey, Principe, Senhor, grande, poderoso, rico affamado, ou dalgua maneira conhecido quem se ha de lembrar de mi [...] Portanto determino de ser eu mesmo meu historiador de minha vergonha e mofinas ${ }^{195}$.

Daí por diante, a forma como D. João de Castro seria lembrado conduz a narrativa dos infortúnios a partir dos quais o público leitor conseguiria reconhecê-lo enquanto portador de boas novas. Por este ângulo, a "vergonha" e as "mofinas", ou seja, o queixume e a ênfase nos sofrimentos causados pelo exílio, de certa forma atrelavam a imagem do letrado a determinadas figuras tidas, de maneira análoga, por pequenas e/ou humilhadas. Por isso é tão importante acompanhar de perto o processo de composição de uma biografia iniciada pelo aspecto que resume grande parte das aflições do autor: a bastardia. De família paterna ilustre, como já exposto, mas de mãe cristã nova (sobre a qual, segundo o exilado, "não convinha dar-me por achado desta parte"), Castro nasceu por volta de 1550 , nem o próprio sabia ao certo. Ainda na infância, foi levado para a casa da avó, esposa do célebre Vice-Rei das Índias. Ali permaneceu até a iniciação da vida escolar no mosteiro de Nossa Senhora de Penha Longa, nas cercanias de Lisboa, onde dedicou praticamente toda a adolescência aos estudos religiosos e demais afazeres da liturgia católica.

Com o propósito de entrar na universidade de Salamanca, Castro fugiu do mosteiro, em 1567, contando aproximadamente dezessete anos, na companhia do colega Manuel Carreira. Como "passarinhos saídos da gaiola”, segundo a biografia, os dois

\footnotetext{
${ }^{194}$ Idem, p. 209.

${ }^{195}$ CASTRO, J. de. Tratado dos Portugueses de Veneza. Op. cit., fl. 423.
} 
julgaram seguir viagem até a Espanha, mas, "guiados" pelo Espírito Santo, foram parar em Évora. Nas cercanias da cidade, porém, a dupla encontrou um castelhano que lhes teria dado dois burrinhos. Arredios, os animais rejeitaram o comando dos jovens portugueses, fato que ocasionou o abandono prematuro das montarias. Na lógica interna do texto a ajuda oferecida pelo espanhol se revelou inútil e, mais do que isso, prejudicial, já que responsável pelo desvio da direção correta.

Na região do Alentejo, o fidalgo encontrou guarida na casa de um tal João Pinto, que o aconselhou a matricular-se na universidade local. Após ter conseguido reunir dinheiro, disse ter alugado um pequeno quarto no centro do qual, curiosamente, via-se uma grande cruz firmemente encravada - logo tida, neste contexto, como sinal de que a Providência velava os caminhos do futuro sebastianista. Meses depois, Carreira, seu fiel escudeiro, regressou à capital, deixando com ele o restante do dinheiro que carregava desde a fuga. Mas, acabados os recursos, o letrado conta ter se tornado um "pobre dos que pediam pelas portas"196, ocasião em que teria encontrado a ajuda de D. João de Melo, arcebispo conhecido por distribuir esmolas aos estudantes carentes da cidade. Nesta época, inclusive, começou a trabalhar em pequenos biscates e, "cada vez mais pobre", voltou a morar de favor na casa do referido João Pinto.

Ainda no começo da vida universitária, um frei, de nome Luís de Lisboa, o teria reconhecido como antigo interno de Penha Longa, fato crucial para o começo do apadrinhamento de João Mendes de Oliveira e sua mulher, D. Beatriz de Vilhena. O casal imediatamente o convidou a morar na residência da família, e, sob a custódia de Mendes, o Morgado de Oliveira, posteriormente morto na batalha de Alcácer Quibir, Castro conseguiu matricular-se no disputado "Colégio dos Colegiais", chegando a desfrutar da "primeira mesa, que era de quinze mil réis por ano"197. A despeito da alegada vida de pedinte, obteve recursos e benesses junto a D. Henrique (então diretor da instituição e, mais tarde, com o desaparecimento de D. Sebastião, feito rei de Portugal) e D. Fernão Martins de Mascarenhas (futuro reitor da Universidade de Coimbra, bispo do Algarve e inquisidor-mor do reino), que possibilitaram ao letrado o usufruto de uma "vida colegial muito melhor que muitos abastados"198, isso sem levar em conta as sucessivas colaborações financeiras de seu progenitor.

\footnotetext{
${ }^{196}$ CASTRO, J. de. Tratado dos Portugueses de Veneza. Apud: AZEVEDO, J. L. de. A Evolução do Sebastianismo. Op. cit., p. 138.

197 Idem, p. 140.

${ }^{198}$ Idem, p. 141.
} 
Esteve no colégio por aproximadamente onze anos, dividido entres os cursos de Artes e Teologia, sendo que o último não chegou a concluir. Após a morte de D. Álvaro, seu pai, e em virtude da bastardia, recebeu diretamente de D. Henrique o arcebispado de São Gião da Silva, com rendimento de cem mil cruzados iniciais. D. Fernando, seu tio, destinou-lhe outra pensão, esta no valor de cinqüenta cruzados. Mesmo com tantos favores, decidiu-se pela saída da instituição argumentado enfastio do mundo acadêmico. Então desmotivado pelo "pouco favor para crescer nas Letras"199, resolveu mais uma vez pegar o rumo de Castela, agora com o intuito de entrar na ordem religiosa dos "cartuxos". Alguns padres teriam tentado demovê-lo da idéia, inclusive um reputado professor de Teologia, o Doutor Molina, prometeu-lhe, segundo o relato, novos favorecimentos para que continuasse em Évora. Irresoluto mas mantendo o destino em segredo, seus planos acabaram sofrendo nova reviravolta: o acometimento de uma "doença gravissima de febres contínuas"200 o teria deixado à beira da morte.

O ano da malograda viagem, curiosamente, é 1578, e o mês em que teria chegado a Lisboa, agosto, é o exato em que D. Sebastião sumiu na África para nunca mais voltar. Na capital, contou ter se hospedado na casa de um dos irmãos, permanecendo na companhia de familiares até o verão do ano seguinte, quando partiu para assumir a "abadia sem cura" dada por D. Henrique. Após organizar a terceira ida a Castela, também frustrada, o letrado despediu-se da terra natal arremessando nas águas do Minho os poemas que compusera durante a juventude. O Minho, aliás, apresenta uma interface entre a biografia e a constituição do sebastianismo:

[...] no tempo desejado hei-de tornar por mercê de Deus a Portugal, e desembarcar em Entre-Douro-Minho, por onde também El-Rei D. Sebastião, parece que há-de começar a restaurar, e tomar posse do seu Reino. O que se assim acontecer: por certo que falou Deus em mim naquele tempo ${ }^{201}$.

Nesta lógica, atribuiu-se a posterior adesão ao antonismo à notícia de que "ElRei de Castela vinha com grande exército pera se fazer senhor de Portugal"202, alegação que buscava diluir a importância de D. Antônio numa genérica defesa do "partido da pátria". O fato é que o engajamento na corte itinerante do Prior do Crato, naquela altura um dos candidatos a rei, ocasionou um irreversível desterro pelo continente europeu.

199 CASTRO, J. Tratado dos Portugueses de Veneza. Apud: AZEVEDO, J. L. de. A Evolução do Sebastianismo. Op. cit., p. 143.

${ }^{200}$ Idem, p. 144.

${ }^{201}$ Idem, p. 147.

202 Ibidem. 
Circulando basicamente entre França e Inglaterra, o letrado estabeleceu-se na capital francesa junto a D. Antônio de Meneses e mais outros dois patrícios, período em que afirmou ter encontrado "alguma miséria pera as bocas de todos" 203 por meio de apostas e jogos de azar. Só com a guarida de outro conterrâneo, chamado Diogo Manuel, foi possível superar, segundo o autor, o "mar largo dos trabalhos, misérias, e desabrigo", as "grandes fomes" e "grandes frios"204 e "finalmente a falta de tudo",205. Corroborando o lado negativo da estadia em terras estrangeiras, Castro dizia que em Paris “o dinheiro dá pois as honras e a valia", já que "tanto vale cada um quanto tem; e tão vil, e de nenhuma valia é; quanto menos tem"206.

A título de digressão, é possível inferir que a avareza parisiense se contrapõe às ações lusitanas para o bem da "república cristã"; que poderiam ser vistas, segundo o autor, nas "santissimas Casas de Misericordia, que ha somente < em tal perfeição > no Reyno de Portugal, e em seus Senhorios"207. Mais adiante, se acrescenta a certeza de que os religiosos portugueses conseguiam repartir esmolas "santissimamente pellos pobres, e neçessitados, com tanta charidade [...] que nem em toda a Christandade ha outra obra, e instituição, que se lhe iguale no regimento" ${ }^{\text {208 }}$. A isso se agrega o fato do letrado ter sido sustentado, durante o período em que esteve em sua terra natal, por diversas instâncias da Igreja Católica e ainda pelos favorecimentos de personagens como D. Henrique, D. João de Melo e D. Fernão de Mascarenhas - os quais chegaram a ocupar postos de primeiro escalão na hierarquia religiosa, o primeiro como cardeal, o segundo como arcebispo de Évora e o terceiro como inquisidor-mor do reino.

Em todo caso, as supostas agruras vividas na França pouco a pouco se incorporaram às interpretações da história política de Portugal. Extrapolando a experiência do exílio, a tópica da dificuldade material imiscuiu-se na própria composição e divulgação da causa sebastianista, como se pode ver no seguinte trecho:

\footnotetext{
203 CASTRO, J. Tratado dos Portugueses de Veneza. Apud: AZEVEDO, J. L. de. A Evolução do Sebastianismo. Op. cit., p. 152.

204 A tópica ovidiana que trata das dificuldades da vida cotidiana e dos incômodos climáticos, com destaque para o frio, foi manejada historicamente de forma a associar uma determinada paisagem a um tipo específico de inadaptação. Na segunda metade dos seiscentos, por exemplo, o francês Joachim du Bellay se queixou do frio das terras italianas, dizendo que a França, comparativamente, era um país ensolarado e de clima ameno. Cf. QUEIROZ, M. J. Op. cit., p. 142.

${ }^{205}$ CASTRO, J. Tratado dos Portugueses de Veneza. Apud: AZEVEDO, J. L. de. A Evolução do Sebastianismo. Op. cit., p. 154.

${ }^{206}$ Ibidem.

${ }^{207}$ CASTRO, J. de. A Aurora da Quinta Monarquia (1604-1605). Op. cit., p. 482.

${ }^{208}$ Ibidem.
} 
Ouso dizer que criou Deus a poucos desde sua meninice, como a mim, como quem sabia o que me estava por vir. Assim lho soubera eu reconhecer. Como não soube nunca que coisa era ter, vestir, comer, vaidades, criados, estimas, senão somente sempre necessidades, falta, vestido simples e mesa de colégio, viver apagado e íngreme, apoucado e sem nome: acostumado a isto, não sentia tanto os vaivens da fortuna, e da opinião: sofrendo, e dissimulando bem com todos os descontos da vida, sem estranhar fome, sede, lazeira, extremas necessidades de comer e vestir; abatimentos, e desesperações humanas. Ajudando-me grandissimamente a levar tudo isto suavemente, a esperança que tinha em Deus de me amanhecer alguma hora. Já, depois de dar na maravilha de El-Rei D. Sebastião: foi o mais guloso conduto dos meus trabalhos, achando muito maior o gosto que eles ${ }^{209}$.

Se o autor não pode ser considerado um cortesão de primeira grandeza, também não é possível identificar nele as "extremas necessidades" e "desesperações humanas" sem que se obliterem suas consecutivas locomoções pelo continente europeu - antes, durante e depois da participação na corte antonista. Tendo isso em conta, não se deve acreditar piamente na "vivência cotidiana" de um "estudante pobre" que compôs uma narrativa "neutra" sobre as condições de vida dos estudantes da Universidade de Évora em fins do século XVI ${ }^{210}$. Nesta mesma direção, João Carlos Serafim afirmou, num breve artigo, que a "situação de penúria" teria levado o exilado a "suportar e superar necessidades e atribulações" 211 . Em sua tese de doutorado, ao contrário, Serafim buscou relativizar o discurso construído, e ainda reproduzido por alguns estudiosos ${ }^{212}$, acerca daquela que teria sido uma "vida desamparada e cheia de privações",213. Na ocasião, o especialista afirmou que, "na tentativa de salientar a probidade e os méritos pessoais", o letrado foi "levado a 'caricaturar' o desabrigo familiar" mais como "estratégia de autopromoção" do que informação procedente ${ }^{214}$.

Mas, além do fidalgo, D. Sebastião e Portugal estariam também exilados, física e politicamente, em ordem respectiva. Noutras palavras, a Espanha "opressora" organiza a narrativa dos eventos ocorridos antes mesmo do início da monarquia dual (1580), engendrando nexos inusitados entre as duas viagens frustradas a Castela e a enfermidade de "grandes febres" com a chamada "sucessão portuguesa", imbróglio

${ }^{209}$ CASTRO, J. de. Tratado dos Portugueses de Veneza. Apud. AZEVEDO, J. L. de. A Evolução do Sebastianismo. Op. cit., p. 155.

${ }^{210}$ SILVA, A. M. P. "Formação académica e vida quotidiana dos estudantes da universidade de Évora nos primórdios da sua fundação - uma leitura contextual". Porto: Revista da Faculdade de Letras do Porto, s/d, p. 153.

${ }^{211}$ SERAFIM, J. C. G. "D. João de Castro (1550? - 1628?)". Op. cit., pp. 122-123.

${ }^{212}$ A este respeito, ver, por exemplo, as já citadas opiniões de Martim de Albuquerque e Aníbal Pinto de Castro, que constam na primeira seção do segundo capítulo, intitulado "Exílio por escrito: história e historiografia".

${ }^{213}$ SERAFIM, J. C. G. Op. cit., Tomo I, p. 10.

${ }^{214}$ Idem, p. 55. 
resolvido em favor de Filipe II. Da fusão dos escritos autobiográficos com a história política resulta a "caracterização disfórica da situação em terra alheia"215; tópica ovidiana que, neste contexto, busca legitimar o discurso sebastianista através da narrativa dos infortúnios e dissabores ocasionados pelo exílio. Extrapolando os queixumes, as memórias do autor objetivavam subalternizar os supostos efeitos negativos do desterro à promessa de redenção pessoal e nacional subjacente ao projeto pentamonarquista; devolvendo assim o devido protagonismo ao Desejado e catapultando o próprio Castro a posições sociais que jamais teria acesso por via natural.

\section{3. Entre a esperança e o desalento: a monarquia universal de um D. Sebastião fracassado}

A obra de mais fino acabamento teórico do sebastianismo não foi propriamente dedicada ao monarca que batizou a crença, pelo menos não inteiramente àquele que herdou a coroa de D. João III, o Piedoso. Tal "contradição" se deve ao fato de, após Alcácer Quibir, a identidade do jovem rei ter sido reivindicada por impostores, mais precisamente quatro, que atingiram elevado nível de conhecimento público, dentro e fora de Portugal. O último deles entraria para a história com a alcunha de D. Sebastião de Veneza ${ }^{216}$, pois dado a conhecer nesta cidade no exato ano de 1598. Na Aurora, o falsário apareceu diretamente associado ao personagem original, o nascido em 1554; como se, para Castro, não houvesse diferença entre um e outro. A exegese castrista exige, portanto, que se redimensione a dinâmica responsável pela aglutinação dos sebastianistas, sobretudo os desterrados, em torno de um líder vivo e supostamente reaparecido. Isso porque, em linhas gerais, por muito tempo a historiografia lusobrasileira relutou admitir os impactos políticos de uma conspiração de proporções internacionais, salvo as pesquisas de João Carlos Serafim e Jacqueline Hermann ${ }^{217}$.

\footnotetext{
215 ANDRÉ, C. A. Mal de Ausência. Op. cit., p. 82.

${ }^{216} \mathrm{Na}$ Aurora, a cidade de Veneza está representada da seguinte forma: pela Praça de São Marcos, pela profecia atribuída aos "bons marinheiros" venezianos que o fidalgo buscou desmentir em favor dos portugueses, pela extensa recolha de material profético, e, por fim, pela idéia de que a suposta reaparição de D. Sebastião na senhoria dos Doges cumpriria a missão de "libertar [a] Italia dos Tyrannos", bem como do Antipapa e seus asseclas. Cf. CASTRO, J. de. A Aurora da Quinta Monarquia (1604-1605). Op. cit., p. 211, 229, 230, 260, 262, 263, 483.

${ }^{217}$ A historiadora, porém, identificou na conjura de Veneza o ponto alto da passagem da fase "política" para a "profética". Se, por um lado, o discurso profético, de maneira inegável, ganhou relevância desde o rompimento com D. Antônio; por outro, tal divisão se mostra pouco operativa na análise do papel desempenhado pelo letrado junto às redes de apoio ao sebastianismo. Corre-se o risco, portanto, de se
} 
Independentemente das chances de êxito, a fabricação de Marco Túlio Catizone enquanto candidato ao trono deve ser entendida como parte das reações de grupos que, mesmo a distância, continuaram vinculados às questões sucessórias do reino lusitano. Graças a eles, a liberdade do calabrês teria sido concedida, em 1600, com a condição de que saísse de Veneza imediatamente, ocasião na qual travou rápido contato com alguns dos portugueses que haviam colaborado para a resolução parcial do caso, entre eles o próprio Castro. Neste cenário, o primeiro objetivo consistia no estabelecimento duma corte de resistência na França, mais precisamente em Paris, onde já residiam muitos dos conjurados. Mas, de última hora, alterou-se o plano de fuga, e Túlio seguiu viagem na companhia do religioso D. Crisóstomo. Detido mais uma vez, agora em Florença, daí por diante as autoridades castelhanas lhe dedicariam sentenças cada vez mais severas: em 1602 o condenaram às galés, e, no ano seguinte, à forca.

Assim, o miraculoso reaparecimento do "Sol de sua Alteza"218 estava comprometido, de antemão, pelo fato de Catizone ter sido esquartejado em São Lúcar de Barrameda há cerca de um ano antes do começo da redação da obra mater. Titubeante ao falar sobre o ocorrido, o letrado sustentou, por um lado, que a detenção do falsário teria durado aproximadamente três annos, tempo que, na sua contagem, se refere ao período de prisão em território italiano, de 1598 a 1600. Por outro, um contraditório D. João de Castro admitiu implicitamente a morte do falso soberano, afirmando com todas as letras ter tomado ciência da "justiça pública" de San Lúcar. Mesmo considerando a pior hipótese, a da morte do rei exilado, o desalento parece ter dado lugar ao otimismo proveniente da interpretação de certas profecias que davam conta da segunda morte do Desejado: uma em 1578, no norte da África, e a outra, na Espanha, em 1603. Neste caso, prometeu-se a volta do D. Sebastião de Veneza para setembro ou outubro "presentes", ou seja, dos anos de 1604 ou 1605.

Sem saber, os castelhanos teriam levado a cabo um assassinato previsto, segundo o autor, numa das etapas do processo de redenção do povo português: "De modo que se os homes não creram que era morto, e não o tiveram por esse: não podia o tal ser El Rey Dom Sebastião" ${ }^{219}$. Pelas mãos de Castro, Marco Túlio se dotava cada vez mais dos sinais reservados ao líder supremo da monarquia universal. Basta perceber que, análoga a de Cristo e de São Sebastião, santo mártir reaparecido após sangrenta execução, a

negligenciar uma série de ralações, por que não dizer políticas, que resultaram na cooptação de muitos dos exilados portugueses. Cf. HERMANN, J. No Reino do Desejado. Op. cit., pp. 189-209.

${ }^{218}$ CASTRO, J. de. A Aurora da Quinta Monarquia (1604-1605). Op. cit., p. 39.

${ }^{219}$ Idem, p. 40-41. 
"dupla morte" do soberano é citada algumas vezes ao longo da Aurora, mais especificamente em quatro ocasiões $^{220}$. Na mais importante delas, concluiu-se, paradoxalmente, que os indícios do falecimento do jovem rei serviriam, na verdade, como "mayor argumento pera elle ser vivo, e aver de aparecer, e lhe poder convir o que esta profetizado: com que se mostra ao dedo ser elle esse admiravel Conquistador" ${ }^{\text {,221. }}$

À luz de notícias e profecias, a tentativa de manter vivo, em torno de um "corpo místico", o antifilipismo que havia levado muitos dos conterrâneos do fidalgo ao infortúnio do desterro, propunha a imagem de um D. Sebastião saído do "papo" da “águia espanhola” para enfim dar vida ao desígnio divino que desde Ourique "quis fazer Reyno e Imperio dum nada que era Portugal" ${ }^{\text {222 }}$; ou ainda para fazer crer que Deus desejava fundar "em nós a mayor Monarchia (que he o Imperio de que fala [o Juramento de 1139]) pera gloria de seu santo nome"223. Neste momento, tudo indica que a tópica imperial ainda fazia sentido nos circuitos letrados do mundo ibérico, tendo inclusive se tornando um dos pilares da própria idéia de redenção no contexto da União das Coroas Ibéricas. O resultado disso se reflete na utilização dum conceito que buscava explicar a ascensão e decadência de diferentes povos, assim como o novo ordenamento da comunidade cristã sob a égide de Portugal e seu monarca reaparecido ${ }^{224}$.

A teoria da transferência da soberania no sentido leste-oeste, rota que, passando pela Europa central, ligaria Jerusalém a Lisboa ${ }^{225}$, é aqui apropriada de forma a renovar as esperanças de "em nossos dias [...] ver tamanhas commoções e alterações; traspassandose o Imperio á Casa de Portugal" ${ }^{226}$. Paralelamente, Castro não via no Sacro Império "mais a Cabeça que pro forma, de maneira que quase não retem mais que o nome"227. Ainda segundo o autor, o SIRG se revelava incapaz de realizar o projeto pentamonarquista, servindo apenas para deter a "Tyrannia Othomana",228, e, futuramente, corroborar a unção papal sobre a dinastia lusitana. Vislumbrados, portanto, através da passagem bíblica em que o profeta Daniel interpreta os sonhos de

\footnotetext{
${ }^{220}$ Cf. Idem, p. 225, 234 e 446.

${ }^{221}$ Idem, p. 208.

${ }^{222}$ Idem, p. 79.

${ }^{223}$ Idem, p. 79.

${ }^{224}$ Para além do SIRG, empregou-se o conceito de império em relação aos turcos e islâmicos e também ao hipotético papado do mítico sumo pontífice "angélico". Cf. Idem, p. 113, 177, 191, 208.

${ }^{225}$ Cf. BOUZA, F. A. Portugal no Tempo dos Filipes. Op. cit., p. 171.

${ }^{226}$ CASTRO, J. de. A Aurora da Quinta Monarquia (1604-1605). Op. cit., p. 97.

227 Idem, p. 441.

${ }^{228}$ Idem, p. 191.
} 
Nabucodonosor ${ }^{22}$, os tempos vindouros veriam a ação direta de um Cristo que a D. Sebastião "nomeo Quinto Monarcha, e a Quinta Monarchia por Portuguesa"230.

É inegável que a ideia de conquista universal adquire a função de reafirmar a preponderância de um gládio temporal que ultrapassaria, além do religioso, todos os que já teriam existido antes ${ }^{231}$. Para além da sucessão de impérios ${ }^{232}$, a Aurora empreende a metamorfose do até então libertador nacional em líder supremo da cristandade, esta pensada a partir do mito de conversão geral ao catolicismo. Unidas e até certo ponto misturadas, tanto a teoria da translação do poder, sendo o reino português o mais importante dos "centros" do mundo, quanto a exegese castrista do livro bíblico de Daniel, objetivavam, por um lado, rechaçar a soberania dos Filipes sobre Portugal, e, por outro, do decadente império alemão sobre a Europa e os cristãos, segundo se infere da afirmação de que o prometido Encoberto "não somente ha de ser Emperador no nome, como ate aquy: mas no mando, e poder, e obedecido" 233 .

De tons peculiares, o referido universalismo da Quinta Monarquia passa obrigatoriamente pelo manejo do mito de união dos luso-espanhóis, mas no sentido inverso ao empregado pela retórica filipina no período. De início, Castro esclarece que, nas profecias, a utilização do termo ibéricos "huas vezes significam os moradores das provincias vezinhas ao rio Ebro: e outras, todos os povos das Hespanhas" ${ }^{\text {234 }}$. Nesta perspectiva, a "correta" interpretação da promessa de um "príncipe invicto" nascido por essas terras deveria ter em conta que o termo "Hespanha" não se referia a um lugar específico, mas a toda Península, inclusive às suas terras mais ocidentais. Prometidas ao governo do monarca nascido na porção pequenina ${ }^{235}$, o profetizado "Senhor universal dellas"236, o letrado dividia a região em duas partes, a saber: a “ulterior”, ou menor, que seria Portugal, e a "çiterior", ou maior, que compreendia os demais reinos.

\footnotetext{
${ }^{229}$ Cf. Idem, p. 100-105 e 134.

${ }^{230}$ Idem, p. 135.

${ }^{231}$ Segundo Luís Filipe Silvério Lima, a Quinta Monarquia “temporal” de D. João de Castro e o Quinto Império "jesuítico" do Padre Antonio Vieira teriam formulado "duas respostas e dois projetos diferentes resultantes de um mesmo substrato comum e mais genérico, definido por [Eduardo D'Oliveira] França como profetismo". LIMA, L. F. S. "Entre o Quinto Império e a Monarquia Universal. Concepções proféticas de poder para o Reino e para o Ultramar". In: SOUZA, L. M.; FURTADO, J. F.; BICALHO, M. F. CASTRO, J. de. Op. cit., p. 560.

${ }^{232}$ Assírio, Persa, Grego e Romano. Cf. CASTRO, J. de. A Aurora da Quinta Monarquia (1604-1605). Op. cit., pp. 100-101.

${ }^{233}$ Idem, p. 122.

234 Idem, p. 455.

${ }^{235}$ Cf. Idem, 447, 452.

${ }^{236}$ Idem, p. 454, 477.
} 
Do ponto de vista "peninsular", o fidalgo sustentava que o pacto firmado na cidade de Tomar, quando Filipe II selou em definitivo sua vitória política, não lograra anular a promessa dada a conhecer em Ourique, muito embora tenha privado os portugueses do "usofruyto da liberdade, da gloria, do nome e do mais"237. E aqui se faz necessário destacar a existência de basicamente dois inimigos da monarquia universal: os de "fora", infiéis e hereges de todo mundo, com destaque para os muçulmanos, e os de "dentro" da cristandade, oponentes particulares de D. Sebastião (sobretudo o de Veneza), ou seja, os espanhóis ${ }^{238}$. Comentando as trovas bandarristas, por exemplo, Castro previu que, durante a conquista do orbe, "muy grande numero de Christãos ha de morrer: matando Deos a muytos por seus peccados, e impenitentes, como ingratos a tão inauditas merçes" ${ }^{239}$. Assim como sucederia com os inimigos externos, tal afirmação carrega a certeza de punições severas ao povo castelhano por parte duma Providência que não haveria de abandonar a gente portuguesa à sua própria sorte.

Por toda "obra mater", diga-se de passagem, há apenas três menções aos Filipes. A primeira vem acompanhada da interpretação do vaticínio joaquimita que prometia "grande revoluçam de Estado",240 ao soberano da Sicília e da Espanha, característica logo associada aos domínios castelhanos sobre partes descontínuas do mundo europeu e mediterrânico, como o provam as sucessivas detenções do falsário de Veneza em território italiano e espanhol. Mostrando-se atualizado politicamente, no fim da obra se vê a única referência de Castro a Filipe III, "que hoje reyna" ${ }^{241}$, em meio a breves comentários sobre um livro consultado na biblioteca da Sorbonne. Também no final, o letrado retomaria eventos de quase três décadas antes da redação da Aurora, fazendo rápida apreciação sobre as propagandas de Filipe II que prometiam "grandes franquezas ao Reyno de Portugal, e cumprindo pouco ou nada [...] tirara com a mesma prudençia muytas cousas, a saber, grandes tributos, e dereitos, e outros intentados seus" ${ }^{242}$.

Buscando conexões com as origens centro-europeias da dinastia que controlava, naquele momento, o império onde o "sol nunca se punha", o antifilipismo de Castro sofistica-se a ponto de associar os Habsburgo castelhanos a personagens da literatura profética responsáveis por aterrorizar a cristandade. Tomando corpo ao longo da obra, a relação é apresentada por diferentes ângulos, em passagens que se debruçam sobre o

\footnotetext{
${ }^{237}$ Idem, p. 74.

${ }^{238}$ Cf. Idem, p. 247, 302.

${ }^{239}$ Idem, p. 174.

${ }^{240}$ Idem, p. 169.

${ }^{241}$ Idem, p. 450.

${ }^{242}$ Idem, p. 478.
} 
profetismo canônico e não canônico. Baseado nos livros bíblicos de Daniel e do Apocalipse, no primeiro segmento previam-se a perseguição do Antipapa aos "Catholicos Romanos obedientes ao legitimo Pastor" ${ }^{243}$, e ainda a fuga dos cristãos de Roma, então tomada pelos "reprovados filhos da Christandade" 244 . No segundo, o livro intitulado Onus Ecclesiae prometia a um imperador da "testa grande" o mando sobre toda a Europa, enquanto certos escritos joaquimitas contavam a história de um precursor do Anticristo, também chamado de "Malho" ou "Flagello", que faria da "cidade eterna" sua "estribaria" e "curral" 245 - evento fortemente vinculado ao "emperador Carlos Quinto, em o açoute que deu a Roma, á cabeça da Igreja, e a todo Consistorio della"246.

Em determinadas ocasiões, a apreciação da literatura profética requeria certo aplainamento das diferenças entre o que D. João de Castro gostaria que ela tivesse anunciado e aquilo que as fontes consultadas "originalmente" tinham a dizer. Nesta linha de raciocínio, a perseguição à Igreja Católica encontrou no saque de Roma (1527) o evento perfeito para fazer de Carlos $\mathrm{V}$ não só o único candidato a protetor do "antipapa", como, através de sua descendência, conectá-lo aos Habsburgo que então governavam Portugal na pessoa de Filipe III - nada menos que o neto de quem havia doado a porção ocidental de seu império a Filipe II, monarca responsável pelo início da União das Coroas Ibéricas. Em poucas palavras, o que o fidalgo chama de "medonha desolação da Monarchia Castelhana" ${ }^{247}$ pode ser considerada a mais valiosa entre todas as tarefas concernentes ao advento da monarquia universal, quando D. Sebastião enfim libertaria o lugar que vinha "descayndo de sua gloria e felicidade" 248 desde seu desaparecimento nos campos de batalha marroquinos, a oito de agosto de 1578 .

A vitória do Desejado sobre toda sorte de inimigos poria fim, segundo o autor, ao último cisma cristão. Além de derrotar a linhagem de Carlos V, os Filipes, a Santa $\operatorname{Liga}^{249}$ deporia o "prostituidor" da "Esposa de Cristo" para colocar em seu lugar o mítico papa angélico. Herdeiro da querela medieval em torno dos dois gládios de

\footnotetext{
${ }^{243}$ Idem, p. 156.

${ }^{244}$ Idem, p. 198.

245 Idem, p. 295.

${ }^{246}$ Idem, p. 308.

247 Idem, p. 444.

248 Idem, p. 267.

${ }^{249}$ Liderada por D. Sebastião, a organização seria composta por quatro monarcas católicos, sendo um deles o lendário Preste João. Ora não passando da vaga afirmação de que eles seriam os "principais", ora tentado agradar os apoiadores internacionais do sebastianismo, como franceses e ingleses, o destaque fica por conta do caráter militar desta que seria a principal rede de combate à ameaça islâmica e heresias internas. Cf. Idem, p. 130, 135, 136, 146, 154, 156, 157, 217, 254, 255, 261, 263, 264. Vale lembrar, por fim, que o manuscrito intitulado Avizos Divinos e Humanos pera os Memorandos Conquistadores, de 1617, teria sido exclusivamente dirigido aos futuros integrantes da chamada Santa Liga.
} 
$\operatorname{poder}^{250}$, o sebastianismo buscou aproximar a imagem do rei salvador à de um líder da Igreja Católica também "messianizado". Por se manifestarem ao mesmo tempo, cria-se que "Este Santissimo Papa" estaria prometido a "El Rey Dom Sebastião pera seu companheiro no espiritual: e o dito Rey ao mesmo Pontifiçe por seu companheiro no temporal" 251 . O idealizado pastor de cariz escatológico deixa entrever, curiosamente, um elemento altamente impregnado na vida e obra do fidalgo: o desterro.

Antes de iniciada a conquista do mundo, o dito papa se exilaria junto ao "povo dos fins da terra, que ha de ser o de Portugal"252. ali oferecendo a D. Sebastião, a pedido do próprio, uma coroa de espinhos como figura da paixão de Cristo ${ }^{253}$. A apoteose em Lisboa representa o encontro místico no qual, "perpetuos na união entre si",254, as esferas temporal e religiosa realizariam a fusão dos anseios católicos com os mais seculares objetivos de "reforma do reino". Diante disso, pode-se dizer que a tópica ovidiana que consiste na "oscilação permanente entre a esperança e o desalento" 255 consegue sintetizar a imagem do Desejado e ainda a própria ideia de monarquia universal sustentada por D. João de Castro. Voltando do Marrocos, na África, onde o monarca original desaparecera, ou da Espanha, mais precisamente de San Lúcar de Barrameda, onde o impostor Marco Túlio Catizone havia sido esquartejado, o fato é que os consecutivos fracassos dos dois D. Sebastião adquiriram a função de anunciar que a definitiva conquista do orbe estava cada vez mais próxima.

\section{4. Calendário sob controle: alteridade de tempos e espaços}

A tópica ovidiana da consciência do tempo e do espaço ${ }^{256}$ exprime a forma pela qual Thomé Pinheiro da Veiga vivenciou seu peculiar exílio na cidade de Valadolide. No que se refere ao tempo, a Fastigimia ${ }^{257}$ parece ter sido escrita em formato de diário, contendo basicamente a descrição das atividades cotidianas do autor. Além disso, é possível coletar informações, esparsas e incompletas, em meio aos comentários que

${ }^{250}$ Cf. SKINNER, Q. Op. cit., "Parte Um: As Origens da Renascença", Capítulo 1: "O ideal de Liberdade", pp. 25-44.

${ }^{251}$ CASTRO, J. de. A Aurora da Quinta Monarquia (1604-1605). Op. cit., p. 347.

${ }^{252}$ Idem, p. 336.

${ }^{253}$ Cf. Idem, p. 118, 156, 227, 264, 362, 363, 367, 480.

${ }^{254}$ Idem, p. 356.

${ }^{255}$ ANDRÉ, C. A. Mal de Ausência. Op. cit., p. 83.

${ }^{256}$ Idem, pp. 82-83.

${ }^{257}$ Título completo da obra: "FASTIGIMIA, OV FATOS GENIAES. Tirados da tumba de Merlim, cõ a demanda do Santo Grial pelo Arcebispo D. Turpim. Descubertos, e tirados a luz, pelo famoso Lusitano Fr. Pantaliaõ de Aueiro, q os achou em hu Mosteiro de Calouros, cõ o seu itinerário". 
davam conta da "outra vês que cá estive" 258 , ou ainda sobre "as duas vezes que estive na corte ${ }^{, 259}$. Infere-se, portanto, que os sete meses contabilizados por Veiga ${ }^{260}$, de fins de 1604 até metade de 1605, se referiam a apenas uma das estadias na então capital do império espanhol. Isso porque, ao termo da obra, se faz menção aos "dous anos que nella estive" ${ }^{\text {261 }}$, deixando no ar uma certa dúvida quanto ao tempo exato em que o letrado viveu fora de Portugal. Descontando-se os sete meses dos tais dois anos, pode-se dizer que a(s) outra(s) estadia(s), ocorrida(s) antes ou depois, teria(m) consumido, na verdade, mais que o dobro de tempo daquela que ficou conhecida através do manuscrito da Fastigimia. Eis aí um mistério ainda não decifrado pela historiografia.

Tema da última parte, intitulada Pincigraphia ou Descripção e historia natural e moral de Valhadolid, a percepção do espaço físico opera na lógica da "necessidade de contrapor os lugares de outrora aos actuais" ${ }^{262}$. Retomando os referenciais perdidos desde a saída do genésico solo, a descrição das paisagens espanholas sempre terá por parâmetro a capital lusitana, exceção feita a Coimbra, onde Veiga havia nascido. Começando por sua cidade natal, há paralelos da igreja de San Benito e do rio Pisuerga com o templo coimbrense de Santa Cruz e as águas do Mondengo, as quais banham a urbe onde está localizada uma das mais antigas universidades europeias. Em relação a Lisboa, as comparações privilegiam o aspecto urbanístico, com destaque para a pretensa vantagem, em termos de dimensões, da cidade que é cortada pelo Tejo. Contudo, a "mais fermoza Praça cercada de cazas que ha em Hespanha"263 equivaleria a dez rossios lisboetas. Valadolide também superaria a terra pela qual Ulisses se encantou em número e qualidade de "cazas grandes" e igrejas paroquiais ${ }^{264}$.

As comparações se estendem para temas da vida cotidiana, como a queixa de Veiga em relação ao lodo que se acumulava nas ruas com certa frequência, fazendo com que os calçados e as roupas não durassem, segundo ele, a metade do tempo que durariam em Portugal. Expandindo os paralelos para o mundo da culinária, os lusitanos se sobressaiam, de acordo com o autor, apenas nas aves, vinhos tintos e marmelos. Já os espanhóis levariam larga vantagem nas carnes de pato, carneiro e vaca, e ainda nas

\footnotetext{
258 VEIGA, T. P. da. Fastigimia. Reprodução em fac-símile da edição de 1911 da Biblioteca Pública Municipal do Porto. Prefácio de Maria de Lurdes Belchior. Lisboa: Imprensa Nacional-Casa da Moeda, 1988, p. 123.

${ }^{259}$ Idem, p. 211.

${ }^{260}$ Idem, p. 173

${ }^{261}$ Idem, p. 329.

${ }^{262}$ ANDRÉ, C. A. Mal de Ausência. Op. cit., p. 53.

${ }^{263}$ VEIGA, T. P. da. Fastigimia. Op. cit., p. 335.

${ }^{264}$ Idem, p. 331.
} 
bergamotas, peras e cerejas. Ressalta-se também a abundância das trutas, rãs e caracóis, e a qualidade do vinho branco, dos licores de ginja, do requeijão e da manteiga, assim como do melão, uva e limão. Além da qualidade dos gêneros alimentícios, Veiga dizia admirar a "liberdade" e "nenhuma inveja" do povo vizinho, acrescentando, de maneira irônica, que Lisboa seria a "melhor terra que cobre o sol" 265 caso habitada por castelhanos, índios ou negros. Neste sentido, o letrado afirmava ser

[...] a gente de Valhadolid facil na conversação, aprazivel no trato [...] aguda e graciosa nas palavras e bem inclinada em todo o seu proceder, e gente verdadeiramente cortezãa nas obras e razoens, muy amigos de levar boa vida e de comer e vestir largo e explendidamente e sempre com alegria, avarentos no adquirir e pródigos no gastar $[\ldots]^{266}$.

Nem as questões de gênero ficam de fora das sistemáticas comparações da prosa veiguista. Em relação aos atributos masculinos, fala-se que o espanhol "menos tratado vay mais galan que o fidalgarrão portuguez"267. Mas, na Fastigimia, é a mulher que recebe particular atenção. As conterrâneas de Veiga superariam suas vizinhas na escrita e, em termos físicos, na beleza dos seios, perdendo apenas no discurso oral. Na tentativa de explicar as diferenças de comportamento, reprovava-se tanto as espanholas serem "biginas", desfrutando de uma criação que "lhes fás não querer apertos de religião"268, quanto as portuguesas "cartuxas”. Faz-se menção, inclusive, a uma dama que não trazia "na boca a liberdade de castelhana", pois levava nos "olhos as prizoens e sujeição de Portugueza"269. Aliás, a "modéstia" e o "recolhimento" femininos seriam "o mayor bem" 270 de sua terra natal, e por isso o letrado considerava inadmissível o "cativeiro servil" ${ }^{271}$ em que muitos de seus compatriotas mantinham filhas e esposas.

No âmbito identitário, os estereótipos caminham no sentido de atribuir características a um ou outro povo, dependendo do contexto. No que se refere ao olhar estrangeiro sobre a Península Ibérica, um embaixador de não se sabe qual nacionalidade teria dito que Portugal "parecia terra dada em dote a genro e não a filho" 272 . Com o mesmo sarcasmo, outro deles teria se referido ao país como "culus mundi",273. Já um

\footnotetext{
265 Idem, p. 361.

266 Idem, p. 353.

${ }^{267}$ Idem, p. 41.

268 Idem, p. 347.

${ }^{269}$ Idem, p. 318.

${ }^{270}$ Idem, p. 146.

${ }^{271}$ Idem, p. 146.

${ }^{272}$ Idem, p. 43.

273 Ibidem.
} 
anônimo mercador de origem francesa dizia que o aragonês era "gente muy corioza e polida", o castelhano "affavel", e o português "não sabia fallar mais que em merda"274. Além deste exemplo, ao longo da obra é possível apreender uma extensa lista de atributos negativos imputados aos lusitanos. Basta lembrar, resumidamente, sua fama de "sujos", “ensebados" e "mal vestidos”275, sendo que, em dada ocasião, o próprio Veiga teria sido xingado de "sevoso",276. Talvez em função disso o autor tenha se queixado reiteradas vezes do "desprezo dos Castilhanos",277, do costume que tinham "de zombar da nossa soberba e vaidade"278, ou ainda de simplesmente "zombar",279.

Nesta perspectiva, é digna de destaque a insatisfação do letrado com o escárnio sofrido por um casal de mulatos e com a imitação que um grupo de "velhacos" fazia da "portuguesada" 280 . Em resposta a uma dama de corte que havia perguntado se todos os seus patrícios eram loucos, Veiga teria dito que eram insanos na mesma medida em que os espanhóis eram "cornudos" 281 . O repúdio prossegue com o acometimento de uma doença em razão da qual dizia não querer morrer longe de casa, já que, nestas circunstâncias, "Castella era Inferno"282. Há ainda a desproporcional alegria em virtude do nascimento do herdeiro do trono, momento no qual o autor afirmou ter se assustado com o "excesso com que os Hespanhoes amam o seu Principe"283. Posteriormente, acerca da cerimônia de batismo ${ }^{284}$, destacou-se a ausência dum representante português, e, no âmbito religioso, compararam-se os pregadores dos dois reinos; não restando dúvida da superioridade dos lusitanos sobre os "charlatães muito solto nas palavras"285, em referência aos religiosos castelhanos.

\footnotetext{
${ }^{274}$ Idem, p. 251.

275 Idem, p. 267.

276 Idem, p. 37.

${ }^{277}$ Idem, p. 120.

278 Idem, p. 175.

${ }^{279}$ Idem, p. 247.

${ }^{280}$ Idem, p. 43.

${ }^{281}$ Idem, p. 247.

${ }^{282}$ Idem, p. 57.

283 Ibidem.

284 Em toda Fastigimia, esta é a única menção aos Filipes. Conta-se que, antes do batismo, as especulações sobre o nome do herdeiro da Coroa davam conta de Alexandre ou Carlos, embora tenha prevalecido a linhagem representada pela "gentileza", "ânimo pacífico" e "mansidão" dos respectivos monarcas que governavam Portugal desde 1580, quando da morte de D. Henrique. A leitura de Veiga sobre a União das Coroas ibéricas pode ser complementada pela imagem de D. Sebastião, o penúltimo rei natural. O letrado considerava a crença no retorno do Desejado uma "superstição da gente idiota" em torno de quem já estaria "em gloria". A asserção deixa claro, em primeiro lugar, a certeza da morte do soberano, e, de quebra, a desaprovação do letrado para com o sebastianismo. Cf. Idem, pp. 81, 314, 315. ${ }^{285}$ Idem, p. 25.
} 
Todavia, em muitas ocasiões as rusgas dão lugar a demonstrações de admiração mútuas, como no caso da mulher de origem flamenca que considerava os portugueses "muy calientes de corazon"286. Para Veiga, como visto anteriormente, o trato com os nascidos em Valadolide era "facilissimo", e a "liberdade muyta"287, além do letrado considerá-los extremamente "cortezãos no fallar"288. A gente espanhola seria "merecedora de ser perpetuamente envejada e imitada",289, elogio que obrigou o próprio autor, segundo suas palavras, a "dizer mal dos meus naturaes"290. Noutra ocasião, opôsse a "largueza dos corações da gente" e a "cortesia de todos" 291 com o inadequado costume lusitano dos beliscões nos braços e nas pernas. $\mathrm{O}$ ápice da comparação está no confronto da alegria dos espanhóis versus a melancolia dos portugueses, seguindo a máxima de que os primeiros viviam como se não fossem morrer e os últimos morriam como se não tivessem nascido para viver. A alegria, sinteticamente, se contrapunha à "carranca" 292 , de modo que o retorno a Portugal é acompanhado da sensação de ser "tudo tão diferente da largueza dos ânimos de Castella"293.

Parte substancial da importância atribuída aos vizinhos reside na fama de que acumulavam grande riqueza, sendo "hoje a mayor que ha no mundo",294. Tal certeza baseava-se na observação dos festejos e cerimônias de "maior grandeza que nenhum Principe pode mostrar" 295 , bem como nos luxuosos banquetes, quando se ostentava a "mais fermoza e mais rica baixella" 296 para servirem os convidados. Símbolos maiores do fausto castelhano, tanto o ouro quanto a prata o autor disse ter visto em "muyta quantidade" 297 , chamando atenção também para o quão "destemida he no gastar esta gente" ${ }^{298}$. Tamanho acúmulo de recursos tem, na opinião de Veiga, uma justificativa. $\mathrm{Na}$ Espanha, acreditava-se que os senhores locais possuíam vastas extensões de terras, enquanto em Portugal, entre outros papéis, elas teriam adquirido a função de dote no âmbito dos casamentos entre membros da nobreza.

\footnotetext{
286 Idem, p. 115.

${ }^{287}$ Idem, p. 245.

${ }^{288}$ Idem, p. 216.

${ }^{289}$ Idem, p. 358.

${ }^{290}$ Idem, p. 359.

${ }^{291}$ Idem, p. 33.

292 Idem, p. 356.

293 Idem, p. 317.

${ }^{294}$ Idem, p. 99.

${ }^{295}$ Idem, p. 84.

${ }^{296}$ Idem, p. 110.

${ }^{297}$ Idem, p. 224.

${ }^{298}$ Idem, p. 117.
} 
No que tange aos acontecimentos europeus, o mais importante deles dá conta, até onde se pode aferir, da morte do papa Leão XI, a vinte e sete de abril de 1605 . O recebimento da notícia em Valadolide, curiosamente, consta já na seção reservada ao dia seguinte. E aqui cabe uma rápida digressão. Neste mesmo ano, mais precisamente a três de março, falecera o papa anterior, Clemente VIII. Embora Veiga não diga abertamente a qual dos pontífices faz referência, tudo leva crer que o personagem em questão é ninguém menos que Alessandro Ottaviano de Médici, nome de batismo do homem que permaneceu apenas vinte e seis dias no mais alto posto da Igreja Católica. Isso porque, em primeiro lugar, se afirmou, de modo sarcástico, ter havido "mais sentimento em sua morte que alegria em sua elleyção" ${ }^{299}$. Mas o maior indício de que realmente se tratava de Leão XI, o Médici, subjaz aos comentários acerca a fama de ter vivido pouco $^{300}$, e, para completar, a menção à piada de que os cardeais desejavam aos mandatários católicos "pouca vida e pouca saúde”"301. Mais lento a chegar, o resultado do concílio que elegeu seu sucessor, Paulo V, só seria abordado a trinta e um de maio, quinze dias, portanto, após a ascensão do romano Camillo Borghese.

Repercutindo estas e outras notícias, mas voltando-se também para o reino natal, em Veiga a idéia de pertencimento aparecerá diretamente impactada pela experiência do exílio, visto que, em terras estrangeiras:

[...] o amor da patria he como o amor proprio e natural, pois queremos ao que fomos e havemos de ser. Alem disso, a lembrança daquelles primeyros anos da nossa mocidade se representa com a mesma saudade e suavidade de amor como do melhor tempo que tivemos e em que comessamos a gostar da vida, sem o pezadume dos cuidados dela ${ }^{302}$.

A partir do retorno a Portugal, portanto, o letrado assumiu ter começado a se "namorar mais da modestia e sujeição da nossa Pátria, que das aparencias phantásticas das estranhas" ${ }^{, 303}$ - uma referência velada, na verdade, ao período vivido em território espanhol. No ápice de sua comoção, o autor confidenciava querer "beijar a doce terra de minha amada patria"304 o quanto antes, garantindo preferir ainda os "disfavores Portuguezes que todas as larguezas de Castella"305.

\footnotetext{
${ }^{299}$ Idem, p. 48.

300 Ibidem.

301 Ibidem.

302 Idem, p. 317.

${ }^{303}$ Idem, p. 318.

${ }^{304}$ Idem, p. 317.

305 Idem, p. 320.
} 
Expressões como desterro e degredo são utilizadas, de forma respectiva, para explicar a punição sofrida pelo neto do Marquês de Mondejar em decorrência de um amor proibido, e para ilustrar o estatuto do filho nascido desta relação, D. Inigo de Mendonça. Ainda em referência a terceiros, o desterro entra em cena como castigo dirigido a quatro religiosos anônimos acusados de "atrevimento" e "ignorância". Quando se reporta à sua condição, Veiga recorda um fidalgo que o teria considerado, junto a outros de seus patrícios, "sempre como desterrados"306. Noutra ocasião, narra-se a efusiva despedida entre "todos os que vinhamos desterrados em companhia",307. Diz-se ainda que, após despedir-se, “desterrávamos para nossas pátrias”, em alusão ao retorno a Portugal. Ápice do tema, aqui parece ter havido a inversão do sentido original da ideia, expressa basicamente pelo movimento de saída rumo ao estrangeiro. Neste caso, portanto, o termo exprime o fim do exílio "tradicional". Ele exprime, na verdade, o inusitado desterro, ou simples locomoção, em direção ao genésico solo.

\footnotetext{
${ }^{306}$ Idem, p. 263.

${ }^{307}$ Idem, p. 301.
} 


\section{Considerações finais}

\section{* Da Valadolide portuguesa ao sebastianismo parisiense}

A Aurora e a Fastigímia não têm o exílio como tema principal, ou não abordam o assunto de maneira explícita. Mas contentar-se com isso significa desconsiderar os elementos subterrâneos que oferecem pistas para a análise da vida dos portugueses que se espalharam pelo continente europeu no começo dos seiscentos. Se comparados ao canto do "mal de ausência" do humanismo lusitano, o desterro de Castro e Veiga pode até parecer discreto, de certo modo diluído em meio a tantos outros assuntos. A despeito da ausência de uma espécie de memorialismo, tais obras não são relatos menos importantes sobre a experiência do "viver fora", já que nelas abundam, de modo "religioso" ou "laico", sofisticadas interfaces entre as trajetórias individuais e acontecimentos políticos de grande importância. É nesta direção que, a nosso ver, as biografias de um tanto quanto de outro estão mais propensas à construção de identidades do que propriamente à perda das mesmas. O exílio enquanto mescla, hibridismo ou bi culturalismo é a prova de que, nestas circunstâncias, uma versão pronta e acabada da identidade nacional não será facilmente encontrada.

Se as semelhanças são poucas, as diferenças não. A começar pelo descontentamento de Castro em relação ao rigoroso e incessante frio da capital francesa, a isso somando a ganância desenfreada por bens materiais e a exagerada importância que ali se atribuía aos títulos de nobreza. Paris é, portanto, o "não lugar" por excelência, e a ela o fidalgo não dedicou nenhuma das milhares de páginas que escreveu durante a vida. No sentido inverso, Veiga esteve longe de recusar os modos e costumes estrangeiros, procurando se abrir para as novidades observadas no cotidiano de Valadolide. No que diz respeito às fontes, o sebastianista se embasou na literatura profética acessada em Évora, num primeiro momento, e, posteriormente, na Itália e França, enquanto Veiga se pautou em suas próprias experiências, prescindindo de qualquer tipo de referência. Outro campo a ser lembrado é o linguístico, onde se pode comparar a utilização castrista das línguas portuguesa e latina com a apropriação do idioma espanhol que quase faz da Fastigimia uma obra bilíngue.

No caso específico do "maníaco de boa fé", a asserção de Edward Said, segundo a qual o exilado necessita reconstruir sua vida a partir de uma "ideologia triunfante ou 
de um povo restaurado"308, lançando mão do "exagero" para impor sua visão de mundo a um meio hostil, parece resumir o sebastianismo que transforma uma acachapante derrota político-militar em prelúdio da justiça comandada por um inusitado soberano revivido. Visto das mais diversas formas, até agora a historiografia não conseguiu entender este longevo fenômeno cultural como "direito de se recusar a pertencer a outro lugar" $" 309$, ou como elemento indissociável da "sensação do provisório e do incerto"310. Nesta chave de leitura, a esperança depositada em D. Sebastião é a forma encontrada para emendar a ruptura irreparável advinda da itinerância vivenciada a partir da adesão ao antonismo, experiência estética que só o nomadismo poderia dar conta de inventar, enquanto "reescritura da história portuguesa"311, a partir dum vigoroso símbolo que ainda hoje parece não ter conseguido se apagar inteiramente.

Fora dos limites estritamente literários, também abundam os exemplos da influência do exílio na vida de D. João de Castro. Um deles pode ser visto, segundo o próprio, no destino reservado ao impostor calabrês e os feitos do Quinto Império estarem simbolizados nas "profecias em figuras" da igreja veneziana de São Marcos. Outro se refere à Remonstrança, obra do começo dos seiscentos que tem por objetivo a divulgação da crença sebástica na França. Para tanto, o letrado pensava publicá-la já traduzida para o francês, embora o plano inicial não tenha se realizado. O último pode ser apreendido da sua relação com as trovas bandarristas, que dizia ter perdido quando da batalha de Alcântara, aquela que selou a derrota de D. Antonio frente aos espanhóis. Disposto a estuda-las em profundidade, procurou algum exemplar das ditas trovas nas livrarias de Paris, tendo então encontrado aproximadamente dez edições. É justamente em virtude da indignação, segundo ele, com as falhas, falsificações, esquecimentos e ignorância dos copistas que decide publicar, na França, a Paraphrase et Concordancia. Por tais motivos, o exílio não é só um lugar. Ele é, acima de tudo, o elemento que fornece condições para a condensação de tradições proféticas as mais diversas em torno de um monarca mitologizado.

A partir do contexto parisiense, aventa-se a possibilidade do sebastianismo ter nascido da mescla do destino profético que caberia a Portugal com os desafios da vida

\footnotetext{
${ }^{308}$ SAID, E. Op. cit, p. 50.

${ }^{309}$ Idem, p. 55.

${ }^{310}$ MONTANÉZ, A. P. Op. cit, p. 36.

${ }^{311}$ HERMANN, J. Op. cit, p. 209.
} 
cotidiana no desterro ${ }^{312}$, o que resulta num discurso contra a realidade do exílio em detrimento da uma "ancestral consciência dos deveres para com a Pátria"313 ou de um estranho "patriotismo místico" "314. Para efeito comparativo, o sefardista Diogo Pires foi outro proscrito que repercutiu a derrota de Alcácer Quibir, chegando a "perdoar" D. João III, monarca responsável pela expulsão de toda sua família, mas não o Desejado, a quem atribuiu a perda da independência nacional ${ }^{315}$. A despeito da divergência de opinião acerca de D. Sebastião, em ambos os casos o exílio pode ter sublimado a figura do soberano, reforçando a conhecida idéia de que a um príncipe (im)perfeito correspondia um reino também (im)perfeito.

Na Fastigimia, a percepção da alteridade parece intensificar os questionamentos identitários como em nenhum outro momento da vida sedentarizada que Veiga conheceria após o retorno ao "Portugalete", como costumava dizer. Uma das tradições da literatura exilada ${ }^{316}$, a atribuição de características a outros povos advêm, neste caso, da própria experiência, do processo de decantação do "vivido" que emana aparentemente desvinculado de alguma proposta de destino coletivo. A escrita em Valadolide formula sistemáticas comparações com o fito de identificar o "ser" português em paralelo com um reino que, talvez mais do que qualquer outro na Europa Moderna, podia se intitular cristão, sugerindo adaptações negociadas e, em algumas ocasiões, elevado nível de assimilação cultural. Seguindo a ideia que José Ibáñez faz dos exilados políticos acolhidos pela Monarquia Católica no começo dos seiscentos, o segredo da adaptação não reside tanto no fato deles "se aferrarem a uma identidade", mas sim no de "se adaptarem aos interlocutores e às conjunturas que encontraram",317.

Falando de temporalidades, a condição do "provisório permanente" assumida pelo sebastianismo castrista se fez perceber como negação de um presente achatado entre acontecimentos pretéritos que corroboravam aspectos messiânicos da figura real e um futuro que assumiu a redenção cristã como bálsamo para as incertezas individuais e

\footnotetext{
${ }^{312}$ Aspecto que ganha maior dimensão no século XVIII, quando a viagem adquire "importância capital na percepção dos espaços e dos homens, na reflexão sobre analogias e diferenças, na adoção ou rejeição de modelos". Cf. BUESCU, A. I. "O 'Peregrino Instruído'. Viagem e poder na Europa setecentista”. In: Memória e Poder. Ensaios de História Cultural. Op. cit., p. 112.

${ }^{313}$ CASTRO, J. de. Discvrso da Vida do Rey Dom Sebastiam. Op. cit., "Introdução", p. 10.

${ }^{314}$ Cf. AZEVEDO, J. L. de. A Evolução do Sebastianismo. Op. cit., p. 83; PINTO, A. C. "Modernidade contra a democracia? O nacionalismo místico de Fernando Pessoa”. In: LIMONCIC, F., MARTINHO, F.C. P. (org.). Os intelectuais do antiliberalismo. Projetos e políticas para outras modernidades. Rio de Janeiro: Civilização Brasileira, 2010, Cap. 2.

${ }^{315}$ Cf. ANDRÉ, C. A. Um Judeu no Desterro. Op. cit., pp. 133, 134, 138, 139.

${ }^{316}$ Cf. VIDAL, P. Op. cit, p. 54.

${ }^{317}$ IBÁÑEZ, J. J. R. Op. cit., p. 127.
} 
coletivas. Em termos práticos, a estadia cada vez mais prolongada em Paris acabou inviabilizando a confecção da narrativa sobre as experiências ali adquiridas. Exemplo disso é o fato de Castro interromper seu relato autobiográfico justamente no período "silenciado" que resume sua longa vivência na França. Só o recurso ao passado mítico amenizou os efeitos negativos atribuídos ao presente e conseguiu fazer dele um período transitório e análogo ao que já teria se passado com outras personalidades da história nacional e da cristandade como um todo. A levar-se em consideração a hipótese de que a impossibilidade do retorno a Portugal $^{318}$ daria "lugar às mais variadas utopias e ilusões"319, a crença sebástica pode aqui ser vista como uma das mais intensas formas políticas de "culto da memória" produzidas por exilados portugueses durante a União das Coroas Ibéricas.

Em Veiga, o presente é alçado a protagonista, embora o frescor do instante envelheça com certa facilidade, na medida em que os acontecimentos se sucedem. $\mathrm{Na}$ Fastigimia, explora-se o que Edward Said chamou de "consciência de dimensões simultâneas" ${ }^{\text {320 }}$, que consiste na observação de elementos estrangeiros tendo em vista os correspondentes da terra natal. Memória e cotidiano, portanto, ocorrem juntos, no âmbito de um "provisório provisório" impregnado pela sensação de retorno e pela delimitação espaço-temporal de um exílio sem maiores consequências para o futuro mais distante. $\mathrm{O}$ dia-dia em solo alheio ignora as duas extremidades da clássica divisão passado/presente/futuro, fazendo da obra um diário até certo ponto enfadonho para os ouvidos contemporâneos. Em outras palavras, o tempo presente autonomiza-se em relação ao "antes" e "depois", acabando por condicionar os rumos duma prosa que está longe de exprimir rupturas traumáticas, seja na origem ou mesmo durante o desterro.

Os padrões clássicos diriam que Castro está mais perto das "marcas ovidianas da ausência", e Veiga, das "características odisseicas do regresso" 321 , no sentido de que suas percepções se voltam para a inviabilidade e para certeza do retorno ao pátrio solo, respectivamente. Diriam ainda haver certo confronto entre um sebastianista

\footnotetext{
${ }^{318}$ Nos Notandos Vários, Castro faz a seguinte menção ao exílio: "Quero que saibam, que em caso que me Deos chamar sem me levar primeiro a Portugal, e ver nelle ao Sempre Bem Vindo Rey Dom Sebastiam, Nosso Senhor, o Encuberto. Que nenhu dos prodígios, e visoens, que tive: foy pro obra de Deos: senão cousa natural, e humana: ou ilusoens do Inimigo [...] Mas levandome o Senhor pera si sem ir a Portugal, nem ver nelle ao Rey tam desejado, e tam esperado: condessoas [as profecias] todas por sonhos, e ilusões: porque sem estes taes princípios, e fundamentos, não podem elas ser verdadeiras." Cf. CASTRO, J. de. Notandos Vários, B.N.L., cód. 4392, p. 351 r. Apud: SERAFIM, J. C. G. S. Op. cit., Tomo II, p. 308.

319 ANDRÉ, C. A. Mal de Ausência. Op. cit, p. 39.

${ }^{320}$ SAID, E. Op. cit, p. 59.

${ }^{321}$ ANDRÉ, C. A. Mal de Ausência. Op. cit, p. 113.
} 
"comprometido com a vida política" versus um "cosmopolita bem-humorado",322, como por vezes se julgaram as figuras de Tucídides e Heródoto. Para além das associações literárias, a recusa aos ditames da União das Coroas Ibéricas e o cotejamento dos modos de convivência devem ser vistos a partir das referências oriundas do lugar de origem, leia-se Portugal, fato que nenhum dos dois conseguiu apagar inteiramente. Ao fim, o impacto do mundo externo adquire dois nítidos sentidos. Na Fastigimia, destaca-se o caráter sociológico das aproximações e distanciamentos entre povos vizinhos, naquela altura integrados como em nenhum outro momento histórico. Na Aurora, o exílio entrevê uma espécie de penitência escatológica que subordina o mito da conversão universal à hegemonia político-religiosa do reino lusitano.

\section{* Sebastianismo além-fronteiras: exílios conectados?}

O curto período que vai de 1578 a 1581 fez surgir núcleos de portugueses exilados em cidades como Paris, Londres, Amsterdã, Toulouse, Lyon e Veneza, para ficar nas mais importantes e numerosas. O exílio de D. Antonio, em especial, funcionou como mola propulsora para a expatriação de homens que chegariam a participar de movimentos subversivos protagonizados por falsos D. Sebastião. Um deles, Gabriel Espinoza, era castelhano, e se manifestou graças ao esforço do frei português Miguel dos $\operatorname{Santos}^{323}$. Curiosamente, a historiadora Ruth MacKay, autora de um livro recente sobre o chamado padeiro de Madrigal, afirmou não querer abordar o sebastianismo, visto que sua obra "tende para o lado da Espanha e não o de Portugal, porque foi lá que a fraude foi encenada" ${ }^{324}$. Ora, dizer que o fenômeno sebástico só pode, ou pôde, acontecer dentro das fronteiras portuguesas é ignorar o pioneirismo e a importância de D. João de Castro, talvez o mais destacado dos militantes. Mais do que isso, incorre-se no erro de "nacionalizar" prematuramente manifestações que não funcionavam sob tal lógica, negligenciando os limites "porosos" entre um reino e outro, e, por fim, a existência de uma cultura política assentada em princípios religiosos.

\footnotetext{
${ }^{322}$ MOMIGLIANO, A. As raízes clássicas da historiografia moderna. Bauru, SP: EDUSC, 2004, p. 68.

${ }^{323}$ Religioso incumbido das exéquias do Desejado antes de ter sido desterrado, a mando de Filipe II, por sua relação com o antonismo. Exilado para dentro da Monarquia Católica, o frei português fixou-se nas cercanias da cidade espanhola de Valadolide, mais especificamente em Madrigal, nas dependências de um convento agostiniano destinado a acolhida de mulheres da alta sociedade. Ali estava, entre outras religiosas ilustres, a filha de D. João de Áustria, que atendia pelo nome de Ana, e que, adepta da farsa, também ofereceria apoio ao falso D. Sebastião.

${ }^{324}$ MACKAY, R. O padeiro que fingiu ser rei de Portugal. Trad. Rio de Janeiro: Rocco, 2013, p. 16.
} 
No limite do argumento de MacKay, não teria havido sebastianismo no Brasil, e as revoltas da Pedra do Reino (1836) e de Canudos (1897) seriam qualquer coisa que não isso. A ideia em si não apresentada novidades, visto que, anteriormente, intelectuais como João Lúcio de Azevedo e Antonio Machado Pires já haviam apregoado a existência de uma crença "deturpada" pela ignorância dos extratos sociais menos favorecidos. No sentido contrário, opta-se aqui pelo caminho oferecido por historiadores como Jean-Frédéric Schaub e Jean Delumeau, que destacaram o "sebastianismo no exílio"325 e a combatividade dos "exilados políticos portugueses",326, respectivamente. Embora focado em outros temas, José Ibáñez observou que o exílio político praticado no Antigo Regime acabava forjando micro sociedades concebidas "a partir de pulsões individuais e representações coletivas ${ } 327$. Recentemente, e com muita propriedade, Luís Filipe Silvério Lima destacou que, imiscuído na política europeia, o sebastianismo seiscentista acaba por se desnacionalizar:

[...] os escritos de Castro organizaram o repertório existente, alinhavaram as profecias e comentários, fundamentaram a eleição do rei e da nação lusitana. Mais do que isso, escrita no exílio e, em parte, intencionando o apoio de outros reinos para sua causa, construiu uma obra dialogando, para negá-las, com outras teorias e interpretações das profecias de Daniel, que identificavam em outras nações, reinos e locais a vinda da última monarquia. A elaboração de um edifício português da Quinta Monarquia fez-se não somente em razão de um Sebastianismo "nacional" e autonomista em relação a Castela. Fez-se também a fim de afirmar a posição capital da monarquia portuguesa entre as outras, nas quais, por sua vez, se constituíam projetos profético-políticos a partir do repertório dos sonhos da estátua e das bestas ${ }^{328}$.

O pentamonarquismo exige que a atenção se volte também para fora de Portugal. E aí parece residir um dos maiores nós historiográficos da atualidade. Se, internamente, as discussões mapearam a circulação de textos e boatos que estão na origem do maior projeto messiânico da história portuguesa, além-fronteiras o sebastianismo ainda não foi totalmente elucidado. No Tratado dos Portugueses de Veneza, por exemplo, o próprio Castro fornece indícios acerca da circulação de pessoas, livros e ideias:

Vendo eu o grande thesouro em que tinha dado, corroborado com alguas autoridades que tinha descobertas nos livros: Dei parte a Dom Antonio de Menezes: e aos companheiros: Os quaes admirados de nova nam pensada, começaramse de alvoroçar, dando ouvidos a ella ate que a creram de todo,

\footnotetext{
${ }^{325}$ SCHAUB, J. F. Op. cit., p. 59.

${ }^{326}$ DELUMEAU, J. Op. cit., p. 184.

${ }^{327}$ IBÁÑNEZ, J. J. R. Op. cit., p. 127.

328 LIMA, L. F. S. O Império dos Sonhos: narrativas proféticas, sebastianismo \& messianismo brigantino. São Paulo: Alameda, 2010, p. 208.
} 
vendo as profeçias claríssimas que a afirmavam. Começamola apregoar em Paris por naturaes, e estrangeiros: escrevendoa eu a Nantes ao Padre Frey Estevam; a Roma e Inglaterra, posto que a tiveram por zombaria, e artifiçio ${ }^{329}$.

$\mathrm{O}$ estratagema que conseguiu mobilizar o maior contingente de exilados teve como protagonista o calabrês Marco Túlio Catizone. Ao todo, aproximadamente duas dezenas de lusitanos participaram da luta por sua libertação. Antonio de Brito Pimentel e Pantaleão Pessoa foram os primeiros a enviar missivas no intuito de informar seus conterrâneos do acontecido. Além deles, há mais três peças chave. A primeira é o frei Estevão de Sampaio, amigo de Castro, a quem forneceu vasto material bibliográfico extraído da abadia parisiense de São Victor. Frei Boaventura de Santo Antonio, a segunda, responsabilizou-se pela disseminação do Discurso do Rey D. Sebastiam em Portugal. Ao terceiro elemento, frei Crisóstomo da Visitação, seria imputada a autoria de cinco apologias ao falsário. O fato é que, no biênio 1603-1604, Estevão, com cerca de sessenta anos, Boaventura, de idade incerta, e Crisóstomo, que contava pouco mais de cinquenta, foram encarcerados em San Lúcar de Barrameda, na Espanha, na companhia do D. Sebastião de Veneza. Todos, sem exceção, se defenderam das acusações alegando algum tipo de demência ou loucura.

Para além da pura citação de nomes, o cosmopolitismo da cultura política do Antigo Regime português pode ser atestado por meio da lista de processados por envolvimento com Marco Túlio. Onze dos vinte e um sentenciados eram estrangeiros, sendo dois calabreses (um enforcado e outro condenado a seis anos de galés), um genovês (libertado com a condição de retornar imediatamente à sua província de origem), um cremonês (açoitado e desterrado logo a seguir), um castelhano (também açoitado), e, por fim, seis napolitanos (um enforcado, dois mandados às galés, dois açoitados e um inocentado). Diante deste quadro, uma chave de leitura da obra de D. João de Castro pode ser encontrada no mapeamento da rede clientelar capaz de ter sustentado, ideológica e financeiramente, um sujeito sem atividade profissional regular; que vivia em busca de favores com o objetivo de satisfazer seus "desejos de fama" e “certas necessidadezinhas" mais imediatas, segundo suas próprias palavras. ${ }^{329}$ CASTRO, J. de. Tratado dos Portugueses de Veneza. Apud. SERAFIM, J. C. G. Op. cit., Tomo I, p.
163, nota 18. 


\section{Fontes}

CASTRO, J. de. A Aurora da Quinta Monarquia (1604-1605). Introdução e Edição: João Carlos Gonçalves Serafim. Supervisão Científica: José Adriano de Freitas Carvalho. Porto: CITCEM/Edições Afrontamento, 2011.

CASTRO, J. de. Tratado dos Portugueses de Veneza, ou Ternario, Senario, e Novenario dos Portugueses, que em Veneza solicitarão a liberdade del Rey D. Sebastião: com huã breue menção do Snr. D. Antonio (1622-1623). Lisboa: BNL (cód. 4387-88).

VEIGA, T. P. da. Fastigimia. Reprodução em fac-símile da edição de 1911 da Biblioteca Pública Municipal do Porto. Prefácio de Maria de Lurdes Belchior. Lisboa: Imprensa Nacional-Casa da Moeda, 1988. 


\section{Bibliografia}

\section{Exílio/Banimento/Degredo/Desterro:}

\section{Livros:}

ALCIDES, S. Estes Penhascos: Cláudio Manuel da Costa e a Paisagem das Minas (1753-1773). São Paulo: Hucitec, 2003.

ANDRÉ, C. A. Mal de Ausência: o canto do exílio na lírica do humanismo português. Coimbra: Livraria Minerva, 1992.

Um Judeu no Desterro: Diogo Pires e a memória de Portugal. Coimbra: Instituto Nacional de Investigação Científica, 1992.

CALMON, P. História da Civilização Brasileira. Rio de Janeiro: s/e, 1932.

CAMARGO, O. de B. Os degredados no Brasil colonial. São Paulo: Gabinete de Investigações, 1944.

CIELENS, I. Trois functions de l'exil dans les oeuvres de fiction d'Albert Camus: initiation, revolte, conflit d'identité. s/l: Uppsala-Acta Vnieersitatis Vpsaliensis, 1985.

COATES, T. J. Degredados e órfãs: colonização dirigida pela Coroa no império português (1550-1755). Lisboa: CNCDP, 1998.

DORÉ, A. Sitiados: os cercos às fortalezas portuguesas na Índia (1498-1622). São Paulo: Alameda, 2010.

FERREIRA, E. S. Origens e formas da emigração. Lisboa: Iniciativas Editoriais, 1976.

FRANCHETTI, P. Nostalgia, Exílio e Melancolia: Leituras de Camilo Pessanha. São Paulo: Editora da Universidade de São Paulo, 2001.

GUILLÉN, C. O Sol dos Desterrados: Literatura e Exílio. Lisboa: Editorial Teorema, 2005.

HESPANHA, A. M. Caleidoscópio do Antigo Regime. São Paulo: Alameda, 2012.

LOBO, A. de S. S. C. História da sociedade em Portugal - no século XV. Lisboa: s/e, 1949.

MELLO e SOUZA, L. de. Inferno Atlântico: demonologia e colonização (séculos XVIXVIII). São Paulo: Companhia das Letras, 1993.

O diabo e a terra de Santa Cruz: feitiçaria e religiosidade popular no Brasil colonial. São Paulo: Companhia das Letras, 1986.

Desclassificados do ouro: a pobreza mineira no século XVIII. Rio de Janeiro: Edições Graal, 1982.

MONTANÉZ, A. P. Vozes do Exílio e suas manifestações nas narrativas de Julio Cortázar e Marta Traba. Londrina: Eduel, 2013.

MORENO, H. B. Exilados, marginais e contestatários na sociedade portuguesa medieval. Lisboa: Editorial Presença, 1990.

NASH, R. A Conquista do Brasil. São Paulo: Companhia Editora Nacional, 1950.

PACHECO, K. A Comunidade em Exílio: Literatura comparada entre Lima Barreto e Roberto Arlt. São Paulo: Annablume, 2013.

PIERONI, G. Banidos: a Inquisição e a lista dos cristãos-novos condenados a viver no Brasil. Rio de Janeiro: Bertrand Brasil, 2003.

Vadios e ciganos, heréticos e bruxas: os degredados no Brasil-colônia. Rio de

Janeiro: Bertrand Brasil - Fundação Biblioteca Nacional, 2000.

Os excluídos do Reino: a Inquisição portuguesa e o degredo para o Brasil

Colônia. Brasília: Editora Universidade de Brasília, 2006.

PONTAROLO, F. Homens de ínfima plebe: os condenados ao degredo interno no Brasil do século XIX. Rio de Janeiro: Apicuri, 2011. 
PRADO, P. Retrato do Brasil. São Paulo: Ibasa, 1981.

PRADO, J. F. A. Primeiros povoadores do Brasil (1500-1530). São Paulo: Editora Nacional, 1939.

QUEIROZ, M. J. de. Os Males da Ausência, ou a Literatura do Exílio. Rio de Janeiro: Topbooks, 1998.

RUY, A. História Política e Administrativa da Cidade de Salvador. Salvador: Tipografia Beneditina Ltda., 1949.

História da Câmara Municipal da Cidade de Salvador. Salvador: Editora da Câmara Municipal da Cidade de Salvador, 1953.

SAID, E. Reflexões sobre o exílio e outros ensaios. São Paulo: Companhia das Letras, 2003.

TAPAJÓS, V. História do Brasil. São Paulo: Companhia Editora Nacional, 1953.

VIDAL, P. A história em seus restos: literatura e exílio no Cone Sul. São Paulo: Annablume, 2004.

\section{Teses e dissertações:}

ARAúJO, J. G. Antonio Vieira, entre o Degredo e a Pátria: Percursos de Saudades. Coimbra, Portugal. Universidade de Coimbra: Faculdade de Letras, 2010.

TOMA, M. Imagens do degredo: História, legislação e imaginário (a pena de degredo nas Ordenações Filipinas). Campinas, Brasil. Universidade estadual de Campinas: Instituto de Filosofia e Ciências Humanas, 2002.

\section{Artigos:}

AMADO, J. "Viajantes involuntários: degredados portugueses para a Amazônia colonial". Revista História, Ciências, Saúde - Manguinhos, vol. VI (suplemento), 2000, pp. 813-832.

"Crimes domésticos: criminalidade e degredo feminino". Revista Textos de História. Revista Textos de História, vol. 6, n 1-2, 1998, pp. 143-168.

"Condenados a viver no Brasil". Revista Textos de História, vol. 5, n” 1, 1997, pp. 134-142.

ARAÚJO, E. "Vida nova à força: degredados em Salvador no século XVI". Revista Textos de História, vol. 6, nº 1-2, 1998, pp. 57-76.

ASTIZ, J. R. "El castigo de destierro en la Navarra moderna: el caso de los implicados en desordenes públicos". Revista Espacio, Tiempo y Forma. Série IV, História Moderna, t. 23, 2010, pp. 129-151.

COATES, T. "O sistema reage à mudança". Revista Textos de História, vol. 6, no 1-2, 1998, pp. 211-238.

CORREIA, E. "A evolução histórica das penas". Boletim da Faculdade de Direito da Universidade de Coimbra. Coimbra, vol. 53, 1977.

CUNHA, E. M. L. da. "O povo cigano e a colonização - Portugal e Espanha, soluções diversas?". Revista Mare Liberum. Lisboa: Comissão Nacional para as Comemorações dos Descobrimentos Portugueses, $n^{\circ} 10,1995$, pp. 173-188.

"O povo cigano e o degredo: contributo povoador para o Brasil colônia". Revista Textos de História, vol. 6, nº 1-2, 1998, pp. 35-56.

COSTA, E. V. "Primeiros povoadores do Brasil: o problema dos degredados". Revista Textos de História, vol. 6, no 1-2, 1998, pp.77-100.

CRUZ, M. A. L. "Degredados e arrenegados portugueses no espaço índico". Revista Textos de História, vol. 6, n 1-2, 1998, pp. 169-184. 
DUTRA, F. A. "Salvador Moreira, cirurgião e degredado no Maranhão, século XVII". In: Revista Textos de História, vol. 6, no 1 e 2, 1998, pp. 101-114.

FERNANDES, F. R. "Os exilados castelhanos no reinado de D. Fernando I de Portugal". Revista En la España Medieval, vol. 23, 2000, pp. 101-115.

"A nobreza, o rei e a fronteira no medievo peninsular". Revista En la España

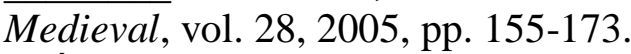

IBÁÑEZ, J. J. R. "Servir segundo a dignidade: exílios políticos e administração real na Monarquia Hispânica (1580-1610)". In.: MONTEIRO, R. B.; FEITLER, B.; CALAINHO, D. B.; FlORES, J. Raízes do Privilégio: mobilidade social no mundo ibérico do Antigo Regime. Rio de Janeiro: Civilização Brasileira, 2011, pp. 105-132.

MELLO e SOUZA, L. de. "Notas sobre a vida quotidiana das degredadas na Inquisição no século XVII”. Revista História: Questões e Debates, no 7, 1986, pp. 256-258.

NASCIMENTO, A. "Recolonização, mutações geográficas e afluxo de degredados a São Tomé no século XIX”. Revista Textos de História, vol. 6, n 1-2, 1998, pp. 9-34.

NEPOMUCENO, L. A. "A imagem da saudade retratada: as epístolas de Cláudio Manuel da Costa". s/e, s/1, pp. 68-80.

PANTOJA, S. "A diáspora feminina: degredadas para Angola no século XIX (18651898)". Revista Textos de História, vol. 6, n 1-2, 1998, pp. 185-210.

PEDROSA, J. M. "El otro portugués: tipos y tópicos en la España de los siglos XVI al XVIII”. Revista Iberoamericana, vol. VII, nº 28, 2007, pp. 99-116.

PIERONI, G. "Detestáveis na Metrópole e receados na colônia - os ciganos portugueses degredados para o Brasil”. Revista Varia História (FFLCH), nº 12, 1993.

"A Inquisição portuguesa e os degredados para o Brasil-Colônia".

Fronteiras: Revista de História, no 7, 1999.

"No purgatório mas o olhar no Paraíso: o degredo inquisitorial para o

Brasil-Colônia". Revista Textos de História, vol. 6, n 1-2, 1998, pp. 115-142.

"Os excluídos do Reino: A Inquisição portuguesa e o degredo para o Brasil-

Colônia". Revista Textos de História, vol. 5, nº 2, 1997, pp. 23-40.

TOMA, M. "Exclusão social, Estado e religião no Império Português". Revista Textos de História, vol. 6, n 1-2, 1998, pp. 241-261.

"A pena do degredo e a construção do império colonial". s/l, s/d, pp. 437-

443.

\section{Sebastianismo/Messianismo/Milenarismo/Providencialismo:}

\section{Livros:}

ARAGÃO, T. Diabruras, santidades e profecias. Lisboa: Vega, s/d.

ASURMENDI, J. O profetismo: das origens à época moderna. São Paulo: Paulinas, 1988.

AZEVEDO, J. L. Evolução do Sebastianismo. Lisboa: Livraria Clássica, 1947.

BERCÉ, Y. M., O Rei Oculto: Salvadores e Impostores. Mitos políticos populares na Europa Moderna. Bauru: Edusc, 2003.

BESSELAAR, J. V. den. Sebastianismo - uma história sumária. Lisboa: ICLP, 1987. Antônio Vieira: profecia e polêmica. Rio de Janeiro: EDUERJ, 2002.

BOTTÉRO, J. Nascimento de Deus: a Bíblia e o historiador. Rio de Janeiro: Paz e Terra, 1993.

CABRAL, O. R. João Maria -interpretação da campanha do Contestado. São Paulo: Companhia Editora Nacional, 1960. 
CAPELO, R. G. Profetismo e esoterismo. A arte do prognóstico em Portugal (séculos XVII-XVIII). Coimbra: Livraria Minerva, 1994.

CHACON, V. Deus é brasileiro: o imaginário do messianismo político no Brasil. Rio de Janeiro: Civilização Brasileira, 1990.

COHN, N. Na senda do milênio: revolucionários e anarquistas místicos da Idade Média. Lisboa: Presença, 1980.

CORREIA. N. O Encoberto. Lisboa: Afrodite, s/d.

D’ANTAS, M. Os falsos D. Sebastião. Lisboa: Heuris, s/d.

DANVILlA, A. Filipe II y el rey Dom Sebastián de Portugal. Madri: Espasa-Calpe, 1954.

DAVIS, J. C. Utopia y la sociedade ideal. Estudio de la literatura utópica inglesa, 1516-1700. Cidade do México: Fondo de Cultura Económica, 1985.

DELUMEAU, J. Uma história do paraíso - O jardim das delícias. Lisboa: Terramar, 1994.

Letras, 1997.

Mil anos de felicidade: uma história do Paraíso. São Paulo: Companhia das

O medo no Ocidente: 1300-1800. Uma cidade sitiada. São Paulo: Companhia das Letras, 1997.

DESROCHE, H. Sociologia da esperança. São Paulo: Paulinas, 1985.

UMESP, 2000.

Dicionário de Messianismos e Milenarismos. São Bernardo do Campo:

O Marxismo e as Religiões. Rio de Janeiro: Paz e Terra, 1968.

O Homem e suas religiões. Ciências Humanas e experiências religiosas. São

Paulo: Paulinas, 1985.

DOMINGUES, J. De Ourique ao Quinto Império. Para uma filosofia da cultura portuguesa. Lisboa: Imprensa Nacional-Casa da Moeda, 2002.

ENTWISTLE, W. J. A lenda arturiana nas literaturas da Península Ibérica. Lisboa: Imprensa Nacional, 1943.

FIGUEIREDO. A. D. Sebastião, Rei de Portugal. 9ª ed. Lisboa: Bertrand, 1943.

FONSECA, R. Portugal e o quinto império por cumprir. São Paulo: Zian Editora, 2006. HERMANN, J. No Reino do Desejado: a construção do Sebastianismo em Portugal séculos XVI e XVII. São Paulo: Companhia das Letras, 1998.

LAPLATINE, F. Mesianismo, posesión y utopia: las tres voces de la imaginación colectiva. Barcelona: Gedisa, 1977.

LIMA, L. F. S. O império dos sonhos: narrativas proféticas, sebastianismo \& messianismo brigantino. São Paulo: Alameda, 2010.

LIPINER, E. O sapateiro de Trancoso e o alfaiate de Setúbal. Rio de Janeiro: Imago, 1993.

LOBO, A. S. S. C. Origens do sebastianismo: história e prefiguração dramática. Lisboa: Typografia da Empreza da História de Portugal, 1909.

MACEDO, J. A. Os sebastianistas: reflexões críticas sobre essa seita ridícula seita. Lisboa: Oficina de Antonio Rodrigues Gualhardo, 1810.

MEGIANI, A. P. T. O jovem rei encantado: expectativas do messianismo régio em Portugal, séculos XIII a XVI. São Paulo: Hucitec, 2003.

NEVES, A. S. Bandarra: o profeta de Trancoso. Lisboa: Edição de Nação Portuguesa, 1925.

PASOS, C. D. Sebastião, rei e mártir: notas acercado livro D. Sebastião de Antero de Figueiredo. Porto: Companhia Portuguesa Editora, 1926.

PIRES, A. M. B. M. D. Sebastião o Encoberto. Estudo e Antologia. Lisboa: Fundação Calouste Gulbenkian, 1969. 
QUADROS, A. Poesia e filosofia do mito sebastianista: polêmica, história e teoria do mito. Lisboa: Guimarães Editores, 1983, 3 vols.

QUEIROZ, M. I. P de. O messianismo no Brasil e no mundo. São Paulo: DominusEDUSP, 1965.

REAL, M. Nova teoria do sebastianismo. Lisboa: Publicações Dom Quixote, 2013.

REDONDO, A. La prophétie comme arme de guerre des pouvoirs, XV-XVII siècles. Études recueillies et présentées par Augustin Redondo. Paris: Presses de la Sorbonne Nouvelle, 2000.

REGO, I. C. Feiticeiros, profetas e visionários. Lisboa: Imprensa Nacional-Casa da Moeda, 1981.

SAMPAIO, J. P. O Encoberto. Porto: Chardron, 1983.

SÉRGIO, A. "Interpretação não romântica do Sebastianismo". In: Ensaios. Coimbra: Atlântica, 1949, vol. II.

O Desejado: depoimentos de contemporâneos de D. Sebastião sobre este mesmo rei e sua Jornada de África. Paris-Lisboa: Livraria Aillaud e Bertrand, 1924.

SERRÃO, J. Do sebastianismo ao socialismo. Lisboa: Livros Horizonte, 1983.

SZACHI, J. As utopias ou a felicidade imaginada. Rio de Janeiro: Paz e Terra, 1972.

VALENSI, L. Fábulas da Memória. A gloriosa batalha dos três reis. Rio de Janeiro: Nova Fronteira, 1994.

VITORINO, P. O Sebastianismo na iconografia popular. Porto: Empresa Industrial Gráfica, 1923.

\section{Tese:}

SERAFIM, J. C. G. D. João de Castro, o 'sebastianista'. Meandros de vida, e razões de obra. Porto: Faculdade de Letras da Universidade do Porto, 2004, 2 tomos.

\section{Artigos:}

CARTOGA, F. "Caminhos do fim da História”. Revista de História das Idéias: História $e$ verdade(s). Instituto de História e Teoria das Ideias- Faculdade de Letras da Universidade de Coimbra, vol. 23, 2002, pp. 131-221.

CHAUÍ, M. "Profecias e tempo do fim". In: NOVAES, A. A descoberta do homem e do mundo. São Paulo: Companhia das Letras, 1998, pp. 453-505.

COHN, N. "Reflexions sur le millénarisme". Archives de Sociologie de Réligions, $3^{\circ}$ année, ${ }^{\circ} 5$, janvier-juin, 1958.

FRANCO, J. E. "Profetismo e a ideia de nação: modelação religiosa do destino de um povo". Revista Religare, no 7, 2010, pp.150-163.

HERMANN, J. "Sonhar o destino: projetos e impasses sobre a grandeza de Portugal". Revista Topoi, vol. 14, no 26, jan./jul. 2013, pp. 188-192.

MAGALHÃES, L. H. "Bandarra e a expansão ultramarina". Revista Textos de História, vol. 13, no 1/2, 2005, pp. 117-143.

QUEIROZ, M. I. P de. "La guerre sainte au Brésil: Le mouvement Messianique du contestado". São Paulo: Faculdade de Filosofia, Ciências e Letras da Universidade de São Paulo (USP), 1957.

"L'influence du milieu social interne sur les mouvements mesianiques brésiliens". Paris: Archives de Sociologie des Religions, $\mathrm{n}^{\circ}$ 5, 1958.

"Classifications des messianismes brésiliens". Paris: Archives de Sociologie

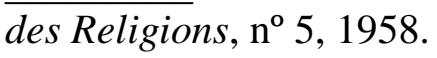

"Autour du Messianisme”. Paris: Présence Africaine, juin-juillet/1958. 
"Mouvements messianiques et développement économique au Brésil". Paris: Archives de Sociologie des Religions, $\mathrm{n}^{\mathrm{o}}$ 16, 1963.

"O movimento messiânico do Contestado e o Folclore". Bahia: Anais da II Reunião Brasileira de Antropologia, 1957.

$8, \mathrm{n}^{\circ} 1,1960$.

“Aspectos gerais do messianismo". São Paulo: Revista de Antropologia, vol.

TORRES, J. V. "Um exemplo de resistência popular: o Sebastianismo". Revista Crítica de Ciências Sociais, $\mathrm{n}^{\mathrm{o}}$ 2, set.-dez., pp. 5-33.

"O tempo colectivo progressivo e a contestação sebastianista". Revista de

História das Ideias, Coimbra, vol. 6, 1984.

RIBEIRO, R. "O episódio da Serra do Rodeador (181701820): um movimento milenar e sebastianista". Revista de Antropologia, vol. 8, n 2, dezembro/1960.

SERAFIM, J. C. G. D. 'João de Castro (1550? - 1628?) - um 'resistente' que se tornou profeta”. Via Spiritus, n 6, 1999.

\section{Diversos:}

\section{Livros:}

ALBUQUERQUE, M. de. Estudos de cultura portuguesa. Lisboa: Imprensa NacionalCasa da Moeda, 2000.

ALENCASTRO, L. F. de. O trato dos viventes: formação do Brasil no Atlântico Sul. São Paulo: Companhia das Letras, 2000.

ANDERSON, B. Comunidades imaginadas: reflexões sobre a origem e a difusão do nacionalismo. São Paulo: Companhia das Letras, 2008.

ANDERSON, P. Linhagens do Estado Absolutista. São Paulo: Brasiliense, 1995.

ARGUEDAS, A. Pueblo Enfermo. La Paz: Libreria Editorial G.U.M., 2008.

AUERBACH, E. Figura. São Paulo: Ática, 1997.

BARBOSA $\mathrm{F}^{\circ}$, R. Tradição e Artifício. Iberismo e Barroco na formação americana. Rio de Janeiro/Belo Horizonte: IUPERJ-UFMG, 2000.

BETHENCOURT, F. História das Inquisições - Portugal, Espanha e Itália. Lisboa: Circulo de Leitores, 1994.

O imaginário da magia: feiticeiras, saludadores e nigromantes no século

XVI. Lisboa: Projecto Universidade Aberta, 1987.

BETHENCOURT, F.; CURTO, D. R. A Memória da Nação. Lisboa: Sá da Costa, 1991.

BICALHO, M. F.; FERLINI, V. L. A. Modos de Governar. Idéias e práticas políticas no Império Português. São Paulo: Alameda, 2005.

BLOCH, M. Os reis taumaturgos: o caráter sobrenatural do poder régio, França e Inglaterra. São Paulo: Companhia das Letras, 1993.

Zahar Ed., 2001.

Apologia da História ou o ofício de historiador. Rio de Janeiro: Jorge

BOUZA-ÁlVAREZ, F. Portugal no tempo dos Filipes. Política, cultura, representações (1580-1668). Lisboa: Cosmos, 2000.

BOXER, C. Império Marítimo Português. São Paulo: Companhia das Letras, 2002.

A Igreja e a expansão ibérica (1440-1770). Lisboa: Edições 70, 1977.

BRAUDEL, F. El Mediterráneo y el mundo mediterráneo en la época de Felipe II. México: Fondo de Cultura Económica, 1995.

BREA, M., GRADÍN, P. L. A Cantiga de Amigo. Salamanca: Edições Xerais, 1998.

BUESCU, A. I. Memória e Poder. Ensaios de História Cultural (séculos XV-XVIII). Lisboa: Edições Cosmos, 2000. 
Imagens do Príncipe: discurso normativo e representação (1525-1549).

Lisboa: Edições Cosmos, 1996.

BULFINCH, T. O Livro de Ouro da Mitologia (A Idade da Fábula): histórias de deuses e heróis. Rio de Janeiro: Ediouro Publicações, 2002.

BURKE, P. Cultura Popular na Idade Moderna: Europa 1500-1800. São Paulo: Companhia das Letras, 2012.

As fortunas d'O Cortesão: a recepção europeia a O cortesão de

Castiglione. São Paulo: UNESP, 1997.

A Escola dos Annales (1929-1989): a Revolução Francesa da

historiografia. São Paulo: UNESP, 1997. O que é história cultural?. Rio de Janeiro: Jorge Zahar Editora, 2008.

A fabricação do rei: a construção da imagem pública de Luís XIV. Rio de Janeiro: Jorge Zahar Ed., 1994.

(org.). A escrita da história: novas perspectivas. São Paulo: UNESP, 1992.

CARVAlHO, J. B. O Renascimento Português (em busca de sua especificidade).

Lisboa: Imprensa Nacional - Casa da Moeda, 1980.

CARVALHO, J. Estudos sobre a cultura portuguesa no século XVI. Coimbra: Universidade de Coimbra, 1947.

CENTENO, Y. K. (coord.). Portugal: mitos revisitados. Lisboa: Salamandra, 1993.

CHEVALIER, J.; GHEERBRANT, A. Dicionário dos símbolos. Rio de Janeiro: José Olympio Editora, 1988.

CIDADE, H. A Literatura Autonomista sob os Filipes. Lisboa: Livraria Sá da Costa, 1940.

COSTA, F. D. A Guerra de Restauração (1641-1668). Lisboa: Livros Horizonte, 2004.

CURTO, D. R. O discurso político em Portugal. 1600-1650. Lisboa: CEHCP, 1988. Cultura Política no Tempo dos Filipes (1580-1640). Lisboa: Edições 70, 2011.

DELGADO, I. Escritores políticos dos Seiscentos. Lisboa: ICLP, 1986.

DORÉ, A. C; LIMA, L. F. S.; SILVA, L. G. Facetas do Império na História. São Paulo: Hucitec, 2008.

ELIADE, M. Mito e Realidade. São Paulo: Perspectiva, 1972. O mito do esterno retorno - arquétipos e repetição. Lisboa: Edições 70, 1985.

ELLIOT, J. H. España y su mundo (1500-1700). Madrid: Alianza Editorial, 1991. La España Imperial (1469-1716). Barcelona: Vicens-Vives, 1998.

FALCON, F. J. C. Tempos modernos. Ensaios de História Cultural. Rio de Janeiro: Civilização Brasileira, 2000.

FEBVRE, L. O problema da descrença no século XVI: a religião de Rabelais. Lisboa: Início, s/d.

Honra e Pátria. Rio de Janeiro: Civilização Brasileira, 1998.

FRANCO Jr. H. As utopias medievais. São Paulo: Brasiliense, 1992.

Peregrinos, monges e guerreiros. Feudo-clericalismo e religiosidade em

Castela medieval. São Paulo: Hucitec, 1990.

FRANÇA, E. D. Portugal na Época da Restauração. São Paulo: HUCITEC, 1997.

$O$ poder real em Portugal e as origens do absolutismo. São Paulo: EDUSP, 1946.

GINZBURG, C. Mitos, emblemas e sinais: morfologia e história. São Paulo: Companhia das Letras, 1989.

O queijo e os vermes: o cotidiano e as ideias de um moleiro perseguido pela Inquisição. São Paulo: Companhia das Letras, 1987.

das Letras, 2001.

Olhos de Madeira: nove reflexões sobre a distância. São Paulo: Companhia 
História noturna: decifrando o sabá. São Paulo: Companhia das Letras, 1991.

2007. O fio e os ratos: verdadeiro, falso, fictício. São Paulo: Companhia das Letras,

GODINHO, V. M. A estrutura na antiga sociedade portuguesa. Lisboa: Arcádia, 1971.

Mito e mercadoria, utopia e pratica de navegar: séculos XIII-XVIII. Lisboa: DIFEL, 1990.

GOMES, R. C. A corte dos reis de Portugal no final da Idade Média. Viseu: DIFEL, 1995.

GUIMARÃES, R. Dicionário da Mitologia Grega. São Paulo: Cultrix, 1982.

HANSEN, J. A. Alegoria: construção e interpretação da metáfora. São Paulo: Atual, 1986.

HARTOG, F. Regimes de historicidade: presentismo e experiências do tempo. Belo Horizonte: Autêntica Editora, 2013.

HESPANHA, A. M. Poder e Instituições na Europa do Antigo Regime. Lisboa: Fundação Calouste Gulbekian, 1984.

História de Portugal. O Antigo Regime, 1620-1807. Lisboa: Estampa, 1993.

As vésperas do Leviathan. Instituições e poder político. Portugal-séc. XVII.

Coimbra: Livraria Almedina, 1994.

HILL, C. A Bíblia inglesa e as revoluções do século XVII. Rio de Janeiro: Civilização Brasileira, 2003.

O mundo de ponta-cabeça: idéias radicais durante a revolução inglesa de 1640. São Paulo: Companhia das Letras, 1987.

HOBSBAWM, E. Era dos Extremos: o breve século XX (1914-1991). São Paulo: Companhia das Letras, 1995.

HALBWACHS, M. A memória coletiva. São Paulo: Centauro, 2006.

HOLANDA, S. B de. Visão do Paraíso: Os motivos edênicos no descobrimento e colonização do Brasil. São Paulo: Brasiliense, 1994.

KANTOROWICZ, E. H. Os Dois Corpos do Rei: um estudo sobre teologia política medieval. São Paulo: Companhia das Letras, 1998.

KOSELLECK, R. Crítica e Crise: uma contribuição à patogênese do mundo burguês. Rio de Janeiro: EDUERJ-Contraponto, 1999.

Futuro Passado: contribuição à semântica dos tempos históricos. Rio de Janeiro: Contraponto-Ed. PUC-Rio, 2006.

LE GOFF, J. O maravilhoso e o cotidiano no Ocidente medieval. Lisboa: Edições 70, 1983.

Os intelectuais na Idade Média. São Paulo: Brasiliense, 1993.

LEVI, G. A herança imaterial: trajetória de um exorcista no Piemonte do século XVII. Rio de Janeiro: Civilização Brasileira, 2000.

LOURENÇO, E. Mitologia da Saudade: seguido de Portugal como destino. São Paulo: Companhia das Letras, 1999.

Labirinto da Saudade. Psicanálise mítica do destino português. $3^{\mathrm{a}}$ ed. Lisboa: Dom Quixote, 1988.

MARAVALL, J. A. Estado Moderno y mentalidade social (siglos XV a XVII). Madri: Alianza Editorial, 1972.

A Cultura do Barroco. Análise de uma Estrutura Histórica. São Paulo:

EDUSP, 1997.

MARQUES, J. F. A parenética portuguesa e a Restauração: 1640-1668. A revolta e a mentalidade. Porto: Instituto Nacional de Investigação Científica, 1989. 
A parenética portuguesa e a dominação filipina. Porto: Instituto Nacional de Investigação Científica, 1986.

MARTINS, P. T. O. Camões. Os Lusíadas e a Renascença em Portugal. Lisboa: Guimarães Editora, 1952.

História de Portugal. $15^{\mathrm{a}}$ ed. Lisboa: s/e, 1968.

MATTOSO, J. Identificação de um país: ensaios sobre as origens de Portugal, 10961325. Lisboa: Estampa, 1988, 2 vols.

MEGIANI, A. P. T. O rei ausente: festa e cultura política nas visitas dos Filipes a Portugal: 1581 e 1619. São Paulo: Alameda, 2004.

MENENDEZ-PIDAL, R. Idea Imperial de Carlos V. $6^{\circ}$ ed., Madri: Espass-Calpa, 1971. MELLO. E. C. de. Um imenso Portugal. História e historiografia. São Paulo: Editora 34, 2002.

MELLO e SOUZA, L. de; FURTADO, J. F.; BICALHO, M. F. O Governo dos Povos. São Paulo: Alameda, 2009.

MICELI, P. O ponto onde estamos: viagens e viajantes na história da expansão e da conquista (Portugal, século XV e XVI). Campinas, SP: Editora da UNICAMP, 2008.

MOMIGLIANO, A. As raízes clássicas da historiografia moderna. Bauru, SP: EDUSC, 2004.

MORENO, H. B. Marginalidade e conflitos sociais em Portugal nos séculos XIV e XV. Lisboa: Presença, 1985.

MORSE, R. O espelho de Próspero: cultura e idéias na América. São Paulo: Companhia das Letras, 1988.

MOTA, C. G. Idéia de Revolução no Brasil (1789-1801). Estudo das formas de pensamento. São Paulo: Vozes, 1979.

ORTIGÃO, R. Últimas Farpas. 1911-1914. Lisboa: Livraria Clássica, 1946.

PAGDEN, A. Povos e Impérios. Uma História de Migrações e Conquistas, da Grécia até a Atualidade. Rio de Janeiro: Objetiva, 2002.

PÉCORA, A. Teatro do Sacramento: a unidade teológico-retórico-política dos sermões de Antonio Vieira. São Paulo/Campinas: EDUSP-Ed. UNICAMP, 1994.

RUCQUOI, A. História Medieval da Península Ibérica. Lisboa: Estampa, 1995.

SALDANHA, A. V. de. Da ideia de 'império' na obra do padre Antonio Vieira: ensaio sobre o universalismo e o pensamento jurídico-político hispânico dos seiscentos. Roma: Consiglio Nazionale delle Richerche, 1992.

SANCHES, M. R. (org.). Malhas que os impérios tecem. Textos anticoloniais, contextos pós-coloniais. Lisboa: Edições 70, 2011.

SCHAUB, J. F. Portugal na Monarquia Hispânica (1580-1640). Lisboa: Livros Horizonte, 2001.

SENELLART, M. As Artes de Governar. Do regimen medieval ao conceito de governo. São Paulo: Editora 34, 2006.

SKINNER, Q. As fundações do pensamento político moderno. São Paulo: Companhia das Letras, 1996.

Hobbes e a liberdade republicana. São Paulo: UNESP, 2010.

SÉRGIO, A. Breve interpretação da história de Portugal. Lisboa: Sá da Costa, s/d.

SILVA, M. C. da. A realeza cristã na Alta Idade Média: os fundamentos da autoridade pública no período merovíngio (Séculos V-VIII). São Paulo: Alameda, 2008.

SILVA, F. C. T.; CABRAL, R.; MUNHOZ, S. (org.). Impérios na História. Rio de Janeiro: Elsevier, 2009.

SUBRAHMANYAM, S. Comércio e conflito. A presença portuguesa no Golfo de Benguela (1500-1700). Lisboa: Edições 70, 2001.

TAVANI, G. A poesia lírica galego-portuguesa. Editorial Comunicação. s/l: s/e, 1990. 
TORGAL, L. R. Ideologia política e teoria do Estado na Restauração. Coimbra: Biblioteca Geral da Universidade, 1981-1982, 2 vols.

VALIENTE, F. T. y. Gobierno e Instituciones en la España del Antiguo Régimen. Madrid: Alianza Editorial, 1999.

VERNANT, J. P. Mito e pensamento entre os gregos: estudos de psicologia histórica. Rio de Janeiro: Paz e Terra, 1999.

WESTPHALEN, C. M. Carlos Quinto: seu império universal. 1500-1558. Curitiba: s/e, 1955.

\section{Teses, dissertações e monografias:}

BARBOSA, E. Tomé Pinheiro da Veiga. O Homem e seu Tempo. Coimbra: Faculdade de Letras, 1966.

CORAL, C. J. O último Avis. D. Antonio, o antonismo e a crise dinástica portuguesa (1540-1640). Dissertação de Mestrado defendida na Universidade de São Paulo (USPFFLCH), 2010.

PERDIGÃO, L. R. A mulher em Fastigimia de Tomé Pinheiro da Veiga. Tese de Mestrado em Literatura Portuguesa apresentada à Faculdade de Letras da Universidade de Lisboa. Lisboa, [s.n.], 1990.

RODRIGUES, E. Fastigínia: a carta interminável. Dissertação de Mestrado em Literatura Portuguesa. Lisboa: Faculdade de Letras, 1990.

TÔRRES, M. R. O Conceito de Império em Marsílio de Pádua (c.1275-80 - c.1342-43) Tese de Doutorado em História Social, UFRJ, 2003.

\section{Artigos:}

ANGELINI, P. R. K. "Fatos geniais de Thomé Pinheiro da Veiga na tradição de narradores dramatizados na literatura portuguesa". s/e, s/d, pp. 526-535.

CARDIM, P. "Religião e ordem social. Em torno dos fundamentos católicos do sistema político do Antigo Regime”. Revista de História das Ideias, nº 22, 2001, pp. 133-175.

"Amor e amizade na cultura política dos séculos XVI e XVII". Lusitania Sacra, $2^{\mathrm{a}}$ série, $\mathrm{n}^{\mathrm{o}}$ 11, 1999, pp. 21-57.

CARVAlHO, J. A. F. "D. Antonio, Prior do Crato, Príncipe Penitente. Os Psalmi Confessionales: do Exemplum à devoção. 1595-1995”. Revista Via Spiritus, no 2, 1995 , pp. 67-129.

DÍAZ-TOLEDO, A. V. "Fastiginia de Tomé Pinheiro da Veiga. Edición de los días 10 y 28 de junio de 1605: primer documento de la recepción del Quijote". Anales Cervantinos, vol. XXXIX, 2007, pp. 309-343.

ÉMIEUX, A. "La Fastigimia (1605) de Pinheiro da Veiga. Ou la vie et la littérature à Valladolid, capitale de l'Espagne". Persée: Bulletin Hispanique, anée 1958, vol. 60, no 2, pp. 226-229.

FERREIRA, V. V. "Tomé Pinheiro da Veiga, um português na corte de Valhadolide". Lisboa: Associação dos Arqueólogos Portugueses, 1988, pp. 49-89.

HERMANN, J. "Um rei indesejado: notas sobre a trajetória política de D. Antônio, Prior do Crato". São Paulo: Revista Brasileira de História, vol. 30, n 59, 2010, pp. 141166.

HESPANHA, A. M. "O Estado Absoluto. Problemas de interpretação histórica". Separata do número especial do Boletim da Faculdade de Direito de Coimbra - Estudos em Homenagem ao Prof. Doutor José Joaquim Teixeira Ribeiro, 1979. 
MARTINS, S. M. G. "A descrição na fastigimia de Tomé Pinheiro da Veiga [Texto policopiado]: representação do olhar". Lisboa: [s.n.], 1990.

NEVES, A. "Tomé Pinheiro da Veiga e a Fastigimia". Boletim Bibliográfico da Academia das Sciencias de Lisboa. Lisboa: Imprensa Nacional, Segunda Série, vol. I, Fasc. $n^{\circ} 1$, Outubro, 1911.

RODRIGUES, E. "Fastigínia: Elementos para uma edição crítica". Românica. Homenagem a Maria de Lourdes Belchior, $\mathrm{n}^{\circ}$ 1-2, 1992-1993, pp. 49-54. 